University of Louisville

ThinkIR: The University of Louisville's Institutional Repository

Electronic Theses and Dissertations

8-1949

\title{
World War I and American public opinion, 1914-1917.
}

Walter Edmund Hicks

University of Louisville

Follow this and additional works at: https://ir.library.louisville.edu/etd

Part of the History Commons

\section{Recommended Citation}

Hicks, Walter Edmund, "World War I and American public opinion, 1914-1917." (1949). Electronic Theses and Dissertations. Paper 1973.

https://doi.org/10.18297/etd/1973

This Master's Thesis is brought to you for free and open access by ThinkIR: The University of Louisville's Institutional Repository. It has been accepted for inclusion in Electronic Theses and Dissertations by an authorized administrator of ThinkIR: The University of Louisville's Institutional Repository. This title appears here courtesy of the author, who has retained all other copyrights. For more information, please contact thinkir@louisville.edu. 
UIVIVERITY OH LOUISVILIE

\author{
WORLD WAR I \\ and \\ MUEICAN PUBLIC OPINION,
}

$1914-1917$

\author{
A Dissertation \\ Submitted to the raculty \\ of the Graduate Sohool of the Univereity of Louisville \\ In Partial Fulfillment of the \\ Kequirements for the Degree \\ of Laster of urts
}

Department of History

By

WAITER EDLUND HIOKS

1949 
This PDF document is a scanned copy of a paper manuscript housed in the University of Louisville (UofL) Libraries. The quality of this reproduction is greatly dependent upon the condition of the original paper copy. Indistinct print and poor quality illustrations are a direct reflection of the quality of materials that are available for scanning. The UofL Libraries greatly appreciates any better copies that can be made available for replacement scans. 
NAE OF STUDEN T: __ Walter Edmund Hicks

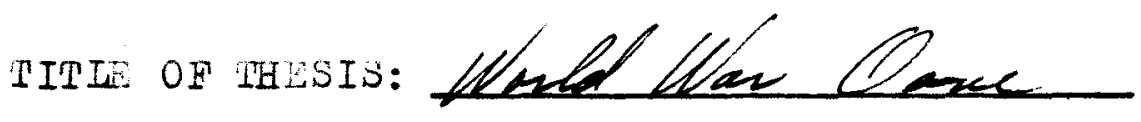
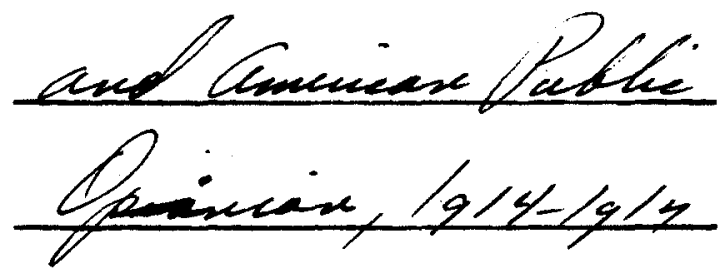

APPAOVED BY WELING CONITTEE CONPOSED OF THE TOLIOWI NG LEIABES:

W. C. Mallalieu

Louis C. Kesselman

NAle OF DIFECTOK: $\quad$ W. C. Mallalieu

DATE: Awoun 1949 
The machinery for weighing or measuring the popular will from week to week, or month to month has not been, ana is not likely to be, invented.

\section{Lord Bryce}

The american Commonwealth 


\section{PREHACE}

Peering into the tomes of history in an attenpt to better comorehend the Anerican mind auring this critical period of our history, the author has encountered many conflicting and ambiguous statenents. But by conparing these opinions and by a detailed study of original sources the author has endeavored to reach logi aal grounàs for his reasoning.

The opinions here offered agree with those of others used, but only because the author through diligent study has arrived at like conclusi ons.

That his own historicsl integrity has not been jeopardized by his faith in others is the author's sincere hope.

\section{WAITER BDINND HICES}

University of Louisville

Louisville, Kentucky

October 10, 1949 


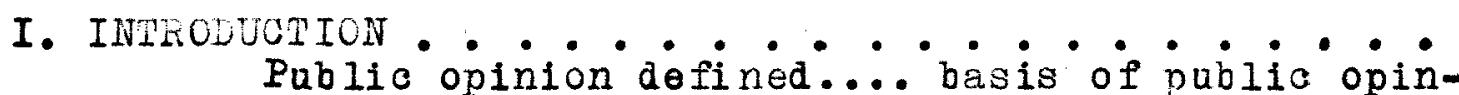
ion.... stereotypes defined.... methods of communication.... measuring puolic opinion.... the rise of public opinion.... press opinion.....uncertainty.

II. THE COURSE AND ACTION OF FOREIGN PHOPAGAIDA. .... Section one- The the ory of propaganda.... basic fundarnentals.... strategio ains.... effectiveness of propaganda.... lines of appeal.... successful propaganda.

Section two- Bacigground of English and German relations wth America.... British organization. ...German organization.... the course of action .... censorship.... reasons for Brit ish victory .... reasons for German failure.... conclusion.

III. THE REACTION OF THE AERICAN RAESS. • . . . . The public reaction to news.... first reaction. ... press polls.... German-American press.... sectional differences.... neutrality.... preparedness.... the submarine warfire.... Zimmerman note.... The 1916 election... peace notes .... armed neutrality.... war.

IV. THE REACTION OF CHURCH $A N D$ PACIFIST GROUPS. . . . Conscientious objections.... the church and state ....initial reaction.... Church poll.... the swing to war.... propaganda and the church.... pacifist reaction.... conclusion.

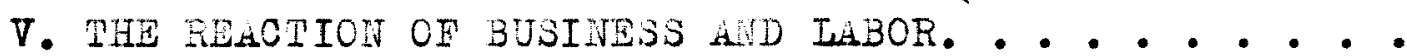
Economic involvement.... British action of the sea.... Germán reaction.... Ioans and credits. ... false prosperity.... Hllied victories.... Labor viewpoint.... conclusion.

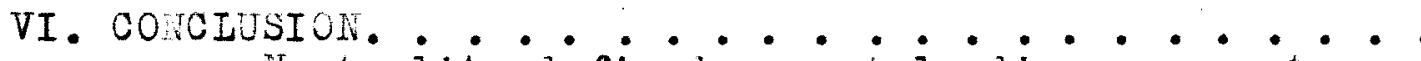
Neutrality defined.... misleading argumonts.... foriner policies.... Presidential reaction.... a logical course.

VII. BIBIIOGRA PHY. . . . . . . . . . . . . . Books.... newspapers.... periodicels.... government oouments. 
WORLD WAR I

and

ALHICAT PUBLIC OPINION

$1914-1917$ 
I. A DZRINITION OF PUBLIO OPINION

When dealing with people, let us remember we are not dealing with creatures of logic. We are dealing with creatures of emotion, creatures busting with prejudices and motivated with pride and vanity.

Dale Carnegie How to Win Friends 
There are many reasons why the role of propaganda, in shaping pablic opinion in international politics and especially in war time, is receiving more careful scrutiny today then heretofore. We live among people who are puzzled more than ever, uneasy and vexed at the unknown cunning which seems to have auped and tanen advantage of their implicit faith in what they read, see and hear. Iittle wonder that there is a new suspicion and in uisitiveness abroad in the world.

Public opinion may be the label for a pseudo-scientific conception. It is also a catch-phrase o great popular power that has veen worn smooth and non-descript by generations of reformers and politicians. Public opinion and the American ideal of the freedon of the press are inextricably and peculiarly woven together in our history. Ihis contributes to the difficulties in distinguishing between public opinion and the press.

Public opinion is a vocalization of the attitudes of individuals concerned ith particular controversial issues. Such openly expressed attitudes are found in complex societies which permit and encourage argumentis and discussions as an essential method of arriving at either a provisional or a final settlement of matters of vital moment to the citizenry. There are, to be sure, many publics fanctioning in a society; one; I

Lasswell, Harola D.: Propaganda Technique in the Worla War, p. 2 . 
as it were, for every controversy which arises ana attracts the attention of a sizeable number or followers. Obviously many of these groupings overlap. Furthermore, in our kind of culture the opinions of these social groups are important. Public opinion may then be defined as a collection of ind viaual opinions representing a range of social groups on a subject of general interest on which there is no unanimous agreement.

Again public opinion is basea primarily upon the culture of the various groups with wilch the mombers are affiliated. Since controversial issues usually involve a conflict of group interests, attitudes towards a controversy are in a large measure determined by the special froups to which the Individual belongs. Thus in controversies, opinions becone irrelevant and confused by the fact that the different groups to which the individusls belong have a variety of notions as to the relative importance of a certain issue. Social attitudes, folkways or cultures are common factors in the mindsets of those involved. They prepare the minds of group nembers to deal with the various classes of problems from numerous points of view. And we must remember, too, that the tempo of our culture does not easily prepare us to see all sides of a question. Of any public event we see at first only a single

1

Iippman, Walter: Publio Opinion, p. 3. 
facet of it. Our picture of it is controlled in part by those who transmit knowledge to us about it. If the event is of secret or semi-secret status, and if little information is available on it, the picture wich taies place in the mind is distorted at once. Furthermore as one attempts to fill in the gaps on the basis of insufficient data in order to complete the picture the resulting imaginings then become known as stereotypes, and a stereotype may be said to be ${ }_{n}^{A}$ simplified and often a distorted and rationalized concept of a group of persons, institution, or situation.

When ax issue arises and a citizen forns an opinion about it, he seldom has the time, interest, or technical sirill needed to garner the facts and the whole story about it even in favorable circunstances when essential facts are available. Instead there is Iikely to be too ready a reliance upon his personal accuired stereotypes to give him his cue. To be sure he knows something about the matter at hand. But that something is likely to be a stereotyped set of alleged facts steeped in unrecognized prejudices surrounaing them. Too often these suffice. Consequently stereotypes simplify the complex world we Iive in and make it seem comprehonsible and manageable and progressive. Stereotypes function also unwarily as defense and escape mechanisns inoculating us against the unconfortable 1 Ibid, p. 81 . 
necessity of changing our minās.

Yet this wrid in which we live is not necessarily the world we want it to be. It is simply the kind of a world we know and. Which we readily become contented with, adjusted to, and offEuard may inevitably expect it to be. For after all this stereotype kind of a world saves us time and might even become what might be described as a handy intellectual, tool if we are not constantiy on our guard. It tenãs also to preserve us from the hust 1 and bustle and confusion of a bewildering world and aids. us in finding pat solutions to personal and pablic problems almost instanteously without provocation. Yes, our opinions are influenced by the folkways, and the mores and the morals of the world or worlds which surround us and of which we are members and which we permit to becone our own noralized and rationalized codification of facts along with an inclination to be too prone to accept at face value.

Public opinion has often oeen generated and comimicated by two extrene: altern ting net oas. One, the application of physical force and, two, the method of persuasion through the use of symbols as illustrated by the witten ard spoken word. The resort to the use of physical torce as a method by which a group is compelied to believe something is so alien to the "american 1

$\stackrel{I b i d}{\rightarrow}$ p. 126 
way" that it can be dismissed at once. The assistance of the alternaive method is therefore seized upon to do the "trick." In the sillful enlistment of this latter method ulterior motives do not come under suspicion. The application of this unsuspected ruse is orderly, painless aid presumbly gives evidence of a respect for the personality of those appealed to. Prostitute the language "to this thing" you want to "get aeross" and that will take care of $1 t$. It will also help to dramatize it, pantomime it, parade it, surrouna it with ritual and audo-visual sugar-coated broaảcast and brochure.

Language is the chief means for shaping public opinion and the clever use of it becos the most reliable method for winning converts to a particular point of view without arousing emotional recoil. American newspapers in the first two decades of the twentieth century 1llustrate the truth of this claim as an incontestable means in coth moulding and controlling the minds of their readers. When it is realized they comprised the only reading material for ninety per cent of the Aierican people during this period we sense immediately the power that they wielded over the minds of men, with each new cdition suppressing or playing up pet angles in behalf of a capitalistic order which might need a little "pruning" or "triming" here and there, but

I

Peterson, H. C.: Propaganda for War-- The Campaien against smerican Neutralitye 1914-1917, p. 7 . 
not very much, in order to usher in the utopia just ahead. lhus have the owners and the hirelings of the press been guilty of finding ways of applying a self-imposed censorship by wich they could preserve the status-quo, protect their vested interests and the monopolies of their friends and followers who approved their maneuvers. Here we have, of course, nothing less than a deliberate attempt to propagandize and bamboozle the readers.

It is likewise well known that corresponaents anà editors are human beings and are consecuently inclined to color the news accoraing to their own ideas. It would be too much to expect them not to do so. With these two classes of writers in mina we can distinguish two so-called brands of censorship: I. The deliberate supression of facts while pretencing to give complete news coverage and 2 . the unintentional circumventing of them. We have here what night be called then the two chief tools at the aisposal of propagandists. And we must hasten to ad that there are many times when the unconscious influences operating are more effective than the deliberate efiorts to produce the coveted ends.

The three questions which are posed for as in the sequence are: 1. Is the information fed to us distorted or not?; 2. 1

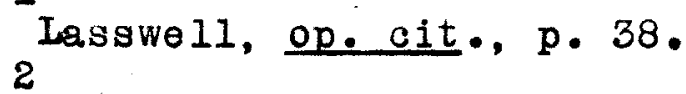

Riegel, Kobert $E$. and others; An Introduction to the Social Sciences, p. 1078. 
Can we judge satisfactorily the notives behind the news presented?; and 3. Is the news distorted deliberately or unintentionally? Such quetions imply the primary reasons why propagande provides no satisfactory glide to one who desires to weigh honestly and seriously the reliability of the information and the arguments used to bolster up the news aduinistered. Propaganaa as such, over and over again, becones little more than a synonym for "lie." Consider as well that propaganda is sometimes defined to mean the presentation of one side as against the giving of both sides. But is it right for one to teach what he believes at long last to bo untrue or dangerous? Such a definition may be requiring that one should do the very thing he is later conaiemned for doing. In other words, is it not true that at times one is obligded to distort the news fed to him in order to teach the truth? But be that as it 7 the word propaganda still remains a word to be used to discredit the information and arguments with Which one disagrees. Nor will it be amiss to recall that the word is used to describe the entrance of ulterior motives. In short, the wora is inextricably intertwined vith all information and activities, oral, written and plotorial, designed to influence and inflame another person's opinion or actions, and honestly recuires the admission that all definitions of the word are often too academio for the many, sinoe the few, have toooften no scale of values other than those connoted by the words "good" and "bad." Consequently, "propaganda," because of the uncertaintieg 
involved pertaining to the ordinary accepted virtues, becomes a smear word standing for something unreliable, something if you please, wich one does not want to have dealings with. It is a word in ill repute. It is used to ajiscreait proposals, notives and actions of people with whom one, for one or more reasons, disagrees. Thus people rarely admit or consider themselves to be propagandists or the things that they think, say, write and do to be propaganda.

In infallable method of measuring and sumarizing public opinion has not as yet been perfected although many are the gestures made in this direction by individuals or organizations in which a pure precipitate of public opinion is vital to their interest. The statement of the leader of the group may be the opinion of the majority represented, but it is seldom the opinion of everyone in the group.

There are incidents of the past which seen to prove conclusively that one hypnotic leader, without the enlistnent of what is referred to as scientific analysis (especially in the field of politios) senses the pulse of public opinion sooner and more accurately than the application of the most scientific methods known to-date. It is also possible that leadership of this kind might be used to swing people into line and on to the band$\overline{1}$

Riegel and others; op. cit., pp. 1080-1082. 2

Iippman, op. cit., p. 3. 
wagon totally unaware of what they are headed for. In this form the one-sided spokesman of a small segment of the population may be knowingly or unknowingly a "tool" of the propagandist.

The rise of public opinion as a significant political and social force dates back to the eighteenth century. It is closely identified with the rise of Middle-class democracy. In due time it became a fetish, blossoming out in the expanding grasp of democratic desires to impregnate the minds of the peoples of Western Europe and America during the last two hundred years. Other familiar associates are: progress, freedom of the press, freedom of assenbly, freedom of speech and freedom of religion. Of these, freedom of the press and freedon of public opinion are intimately linked together in their history and this interrelatedness contributes to one of the difficulties in aistinguishing between public opinion and the "news." With the rise of the printing and newspaper industries it was but a short step for newspaper proprietors to proclaim that their journals reflected the "public interest." 1

To repeat, the opinion of a single newspaper does not reflect the opinion of the hoi-pollo1. It may be the opinion of the owner, editor or correspondent or the opinion of that sinall segment of the public which is vitally interested in the newspapers continuance and the furthering of vested interests known or unknown. is survey by a newspaper, in the period under consid1

Wilson, Iogan and Kolb, Vill1am: Sociological Analysis, (Tee, Alfred McClung. Public Opinion in Relation to Culture p. 310 
eration reflected, for example, only a rough approximation of public opinton at best, but no more, for, at that time we had no device for measuring the opinion of a whole nation's population with any degree of accuracy. Neither did the surveys such as those conacted by the Iiterary Digest reflect the concerted opinion of the entire country when they were made. They often only reflected opinions of aifferent newspapers througho the nation. And, to be sure, there is the remfote possibility that the individual newspaper reflected the correct opinion of the whole area to which it catered, but the chance of this being the case was very slight. Again there is the possibility that the newapaper was powerful enough to form ana control public opinion within a certain area at a certain time, due to the fact, let us say, for example, that the newspaper comprisea. the sole reading material for ninet $z$ per cent of the American people during the period, 1914-1917. Jut such conclusions are subject to correction.

The polls undertaien by the Iiterary Digest during the above mentioned period of our neatrality were forerunners of our more elaborate polls today. Then, there was no breaining down of the population into classes, eithereconomicaliy or socially. When the general public was polled the list of names came either from the Digest's own mailing list or from the telephone directory or some other more or less comparable listing. Nor did the poll consider the full range of possible opinions in a complex society and whether these ideas had been jelled to the place I

Peterson, op. cit., p. 7 . 
where they could be said to be based on abiding convictions. Besides the opinions recorded from such polls were too few in number, too shallow in depth and conse uent Iy altogether unreliable. However, ine inaccuracy of these polls should not be charged to a false accounting of the organization conducting the poll. In the case of the Iiteracy Digest it must be remembered, in fairness, that the magazine was atteupting to break neviground and to secure a whole ration's opinion with the only known instrument at hand. In this case the editar was not a social scientist or a politician but a business man intent on trying to devise a sound method of polling the nation to detect its pulse for the benefit of the readers of h1s magazine. This step marked the birth of that which has since developed into what we now believe to be a "scientific instrament," even though the public opinion polls in vogue today likewi se have their weaknesses.

The more or less scientitic poll of today however takes cognizance of the ideological differences thet have come to play $s$ uch a tremenajuous role in American polities, and today's authorities in this new endeavor realize the potential danger here and are now engaged in experimenting with more and more reliable tools capable of measuring the intensity and breadth of the opinions held. The progress that has been mae through the use of batteries of related questions have shown that "frames of reference.. .. relatively firmly rooted" in "personal values" are credited 1 Wilson and Kolb, op. cit., p. 321. 
with obtaining "essentially the same results" from different types of questioning from different points of view. Such an elaboration of the questioning provess may lead eventually to a reliable recording of the sentiments involved and a recognition of the important part they play in a more inclusive tabulation of public opinion. And it is a long step between the expression of a socially acceptable to lerant opinion and literally being more considerate of another's religious and racial loyalties in the give and take of everyday living.

so despite the knowledge that no instruments were available in 1914 to gauge accurately the opinion of the American people we are reasonably safe in sajine that at the outbreais of the European. struggle they favored a policy of ne utrality. They seemed determined to stand by that policy. Having said this we must also readily admit that there is no short cut to the arriving at such a conclusion in an effort to discbver why the therican people, detesting war and in faror of staying out of it, did enter 1t. Here emerges the necessity for looking at the social, economic, and religious sources and causes, stereotypes and ldeologies if we would know and be assisted in solving the problems confronting us today.

I

\section{Ioo. cit.}


II. THE COURSE $A N D$ ACIION OF FOREIGN PRO PAGANDA.

Section one: The theory of propaganda. Section two: Reality.

Let any man speak long enough, he will get believers.

Stevenson

The Master of Ballantrae 


\section{PHEORY}

The act of persuasion, known today as the art of propagandizing, is as old as history but it was not until the present century that it jecame known as an art or traie. In the complex world of today we are continually attempting to "swing" votes and power to our own trend of thought and the use of propaganda is now very commonplace. The use of propaganda to indoctrinate and to prosecute a war has made it an everyday term.

There are basic fundamentals that must be followed in all propaganả. One 1 s to adhere to the truth as close as possible. Another basic idea is to arouse the interest of specific groups. and a third is to nullify inconvenient ideas, always remembering too, that to secure a wide appeal one should usefstraight-forward manner or style. It should be written or spoken in a simple style so that it may be understood by.the "man on the dociss, or the peddler on the street corner." Paul Goebbels stated that propaganda must always be essentially simple and repetitious, for in the long run the successful propagandist is the person who is able to "reduce probleins to the simplest terms and who has the courage to keep forever repeating them in this simplified form despite the objections of the intellectuals. ${ }^{1}$

The strategic aims or four major objectives of Allied propaganda were:

1

The Goebbels Diaries, p. 119. 
1. To mobilize hatred against the enemy.

2. To preserve the Irlendship of Allies.

3. To preserve the friendship, and if

possible, to procure the cooperation of neatrals.

4. To demoralize the enerny. I

To mobllize hatred against an enemy the propagandist must first accuse him of being quarrelsome, crude and destructive. He is degenerate in his conduct of the war and conducts a lying propaganda. Then call him names and picture what the world would be like if the enemy did happen to be victorious. The war can also be represented as a war of race or as a holy war. The enemy invariably mobilizes irst against a defenseless nation, either openly or secretly, and cormits acts of war. The enemy further incriminates himself by endeavouring to maneuver our governient into the position of an aggressor and by doing this he stands on a record of lawlessness, violence and malice, which offers unassailable proof of a deliberate intent to main or destroy our great nation. To further his cause and build up this hatred the propagandist attemtps to convince the public that his nation has entered the struggle to save business, family and church, and to add to prosperity, security and faith. Thus the enemy becomes the enemy of 2 each and every one of us.

Similar tactics can be used regarding allies, with whom ties of friendship should be preserved. The propaganda to bring

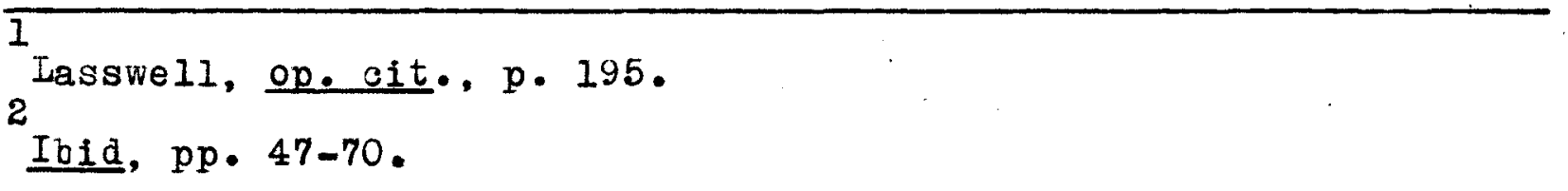


this about ma include constant assertions of respect and demonstrations of esteem, such as observing the allies' chief holidays. In seeking to influence ne utrals the propagandist must introduce to the ne utral the ia ea that his enemy is the neutral's enemy, and thus get the neutral to identify himself with the war aims of the propagandist.

The demoralizing of the eneny is chiefly accomplished, OI course, by defeating him in the field. But the propagandist's part is to convince a nation that its troops are wavering. Ieaflets and other printed propaganá may have little effect, but when one's own nation's events maire propaganda read as a lie, national demoralization sets in.

It must be enphasized that a group canot be sure that its efforts will accomplish the aesired results, as propaganda has definite limitations. The willingness of the people to believe, brought about by other influences in their environment which have been so strong that their thinking patterns are set, destroys its effectiveness. Finally, its effects are limited by counter-propaganda, which may be consiaered as the propaganda of the opposing faction. Propaganàa is also limited in its inability to control

1

2 Ibid, pp. 114-126.
3 Peterson, op.cit., preface.

4 iegel, K. E., onecit., p. 1087 .

Ogburn, william F. and Nimkof, ileyer F.: Sociology, p. 298. 


\section{Page 16 \\ Missing from the \\ original thesis}

Page 16

Missing from the

original thesis 
lists of war aims were pointed largely at home audiences but such statements were also intended to influence neutral opinion. The various classes of American society had to be influenced but without antagonizing other classes. Social reform may be held out to wage-earners but midale-class people are likely to give their approval to war aims of a political or juristic character.

"If the problem of reconstructing the world is to be shorn of an apparent class bias, it must be concefived as a problem of a politico-juristic nature, for talk about world le gislatures and courts tends to ingratiate itself where proposals for the administration of raw naterials by world action, and for the use of the world taxing power to level up existing inequalities of opportunity are suspect." 2

The Ireague to Enforce Peace $(1914-1919)$ is the best example of this branch of successful propaganda/to arise during the period of our neutrality.

The active propagand ist is certain to have a helping hand from everybody with an axe to grind. Those groups who do not take action immediately can be biought into the realm of the propagand ist gradually, without their direct knowledge, by bringing to light those things which are of special interest to the group. To the economic and ecclesiastical groups already referred to could be added a constellation of artists, scientists, teachers, or sportsmen without end. The members of the talkative

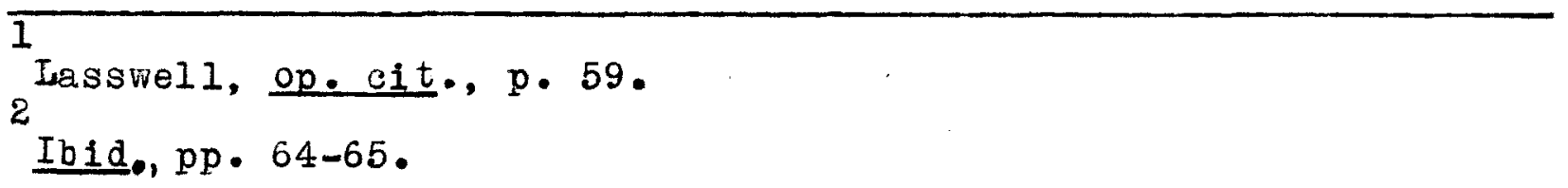


professions who depend for the ir living on their ability to arouse emotions are practicaliy ind ispensable.

Slowly but surely the successful propagand ist brings his unsuspecting victimf into the realm of imagining himself in the cola cruel var via, one way or another. We must remember that most people are more interested in themselves than in anything else in the world. So when the propagandist has involved the public in the struggle to the extent that the welfare of the person depends on the outcome of the war, following the general pattern placed before him, the propagandist has succeeded.

For a meraber of the general public who has been victimized this way it proves exceedingly hard to trace the connection between the responsible authorities and their propaganda. Then drastic action by the government follows a heavy outpouring of propaganda and the officials are questioned as to their authority for such action, they may contend that the pressure of public opinion forced their hand. Thus it is a vicious circle once again; one a slave to the other. So far as there are focmulations of public opinion, legal rules cannot exist until public opinion has become fixed and settled, and cannot well change until plolio opinion has definitely changed. It follows that law is likely to

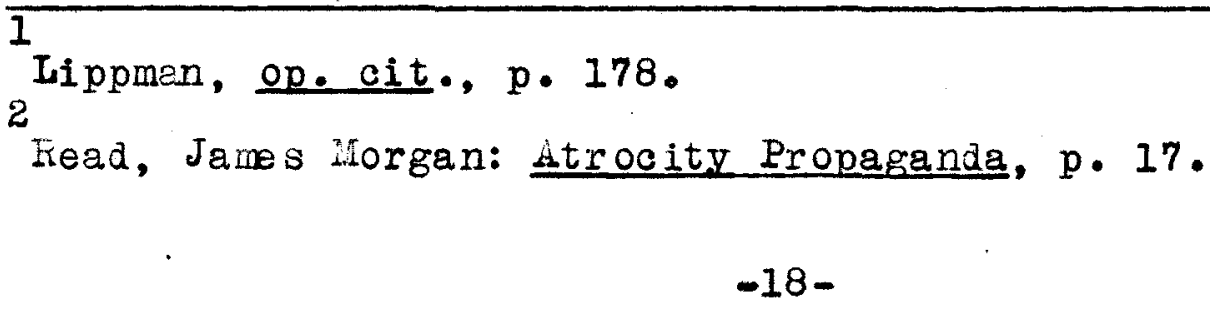


lag somewhat behina public opinion whenever the latter is active 1 and groving. Thus the necessity arises for the government to mould the opinion of the public until the public demards that the measures proposed by the authorities are made law.

The successful propagandist is the one who can create confusion anong his victims and out of this confusion mould their rainds to do his bldding in an unsuspecting manner. He must be careful not to let the confusion lead to mob-violence where this might cause antagonism to all that he is attem ting to create in their minds. Dividing their thoughts and then conquering them by directing their thoughts into the channel he has prepared $\gamma_{2}$ is his main attaci. Lobs can also create fear and thas be good propaganda at times.

The minds of the general public mast be made to justify their part in the struggle. This is brought about by the general wish of $s 11$ mankind that good be triumphant in the universe. It must, therefore, be that one's own retion is vindicating the right against the vrong. In the very act of delivering the blow the nation calls for unity and victory. It is the business of the propaganaist to amplify and repeat the call. Then as right makes inight, the mind assumes the idea that we are struggling with the enemy in the name of peace and security. This is the

\footnotetext{
1

Ford, James: Social Problems and Social Policr, p. 897. 2

Gillette and Reinhardt, op. cit., p. 643.
} 
greatest war aim and in it the public finas the "peacefulness of being at war."

"When the public believes that the enemy began the war and blocks a permanent, profitably and godly peace, the propaganaist has achieved his supreme parpose." 2

$-0-$

1

Lasswel 1, op. cit., pp. 54-58.

2

Ibid, p. 77 . 


\section{ACTUAL PEACTICE}

Dvery ation in the war tried to procure the friendship and, if possible, the cooperation of the United States. But Great Britain, worldly wise from the experiences gained through the governing and controlling of her great empire, had an early start in the atte pt to mould the American mind. In a sense this headstart was not brought about by airect propaganda but by friendly incidents in international relations. One inciaent involved the Venezuela boundary dispuie in 1896 which threatened war between the two English speaking nations in the application of the Ifonroe Doctrine. When the action became public, prominent men in both countries threw their weight to the side of conciliation. Joseph Chamberlain, an influential nember of the cabinet, expressea of ticial British opinion when he declared in a speech in birmingham in January, 1896, "We do not dovet one single inch of American territory. War between the two nations would be an absurdity as well as a crime. I should look forward with pleasure to the possibility of the Stars and stripes and the Union Jack floating together in defense of a common cause sanctioned by humanity and justice."

Further cementing of Anglo-American friendship was fostered by an incident at the Battle of ilanil Bay, when the

$\overline{1}$

Bemis, Samuel Flagg: A Diplomatic History of the United States, p. 421 . 
British fleet (as the newspapers reported it) checked a possible 1

German intervention. ( This story was much exaggerated, but had influence.) At any rate, British diplonacy favored American policy during the Spanish War and after.

Since the turn of the century America had been favored with a stream of anti-German propaganàa from lreat Britain. Since stuerican newspapers rarely intained correspondents on the continent their foreigh news came by way of Lond on, where it was highly colored by the anti-German policies of The Pimes and other British newspapers, most of it enanating from newspapers owned or controlled by Lor Worthcliffe.

This headstart of fifteen years in the battle of propaganda stood Great Britian in good stead. Their immediate problem at the outset of war was to assure themselves of the support of the leaders of dimerican life, and in this regard they were

$\overline{1}$

Rhodes, James Ford: History of the United States, Vol. 9, p. 160. 2

Iord Northcliffe, (1865-1922) in 1908 obtained control of the Iimes, to own wioh had always been one of the aims of his life. From 1900 onwaras, through his newspavers, he had exercised an ever-increasing influence on politics. He had at one time been anxious, like Daward VII, and Cecil khodes, to obtain a friendly understand inc between. England and Gemany, but Gernan policy auring the Boer war caused him to abandon the iaearas impract1cable. His newspapers consistently pleaded the cause of a strong navy, and as consistently warned the nation for 20 years of the peril from Gerany. From 1902 he sought to effect an entente with irance, and a Iso to promote agreements vii th Russia and the United states, whose sentiments and prejudices he had learnt in many visits. Before the United states entered the war he was offered and deolined the post of British AInbassacor at vashington. He also owned the Express and the Daily Hail. The Encyclopedia Britannica, 14 th Ea. Vol. 16, p. 526. 
fortunate. The Anerican aristocrat was distinctly Anglophile. To assume a pro-British attitude was the "thing to do" among cultured americans. This was accentuated by the fact that the economic aristocracy did most of its foreign business throkgh Ion(1) don. One of the liforgan partners, Thomas Lamont, stated: "Like most of our conteruporaries and Iriends and neighbors we (f. P. Norgan and Compang) wanted the Allies to win the war from the outset. We were pro-Ally by inheritance, by instinct, by opinion." At the beginning of the struggle to control opinion Gerrany possessed one advantage. Next to the British Isles, Germany had a tion. The greater number of German-Ame ricans were of the second or third generation, men whose fathers or grandathers had entered the country between the forties and the nineties of the last century and were now assimilated. After the United States entered the war they were patriotic, with only a smell minority being traitorous, but previously they voiced pro-German opinions. Also unfrienaly to the silies were the Jews who had been persecuted by the Kussians, England's Ally, ana the Irish who could never forgive the British Empire for its subjection of Iteland. The

$\overline{1}$

Peterson, op. cit., p. 8 . 2

Time Ihagazine, Vol. XXVII, No. $3($ Jan. 20, 1936) p. 16. 3 Millis, Walter: The hoad to war, p. 6. 
Germans had conảucted a form of propaganda, starting in 1902 when the raiser's brother, Prince Henry, visited America. A museum of vernan culture was established at Harvard; an exchange professor was sent to Columbia; a number of prominent Americans were given honorific ribbons to wear, but such feeble efforts made little headway against the British, and in 1914 American publicists with any views at all on foreign affaics were apt to be rather pro-British and anti-German.

Hany prominent vermans were aware o the task that

faced the iatherland without a stupendous propaganda campaign to counteract the flow of British words. One of these men was Dr. Ernest Daenell, a leman University professor.

"Nothing has occurred in the past which Anerica can charge against us, yet there is one tremendous obstacle, between America and Germany.

"We must overcome the peculiar historical feeling existing betwen smerica and England; for those Ame ricans who are responsible for Americen politics and for the shaping of public opinion are of anglo-Saxon extraction." 2

From the very beginning or the war, vermany, like all of the warring nations, conducted a campaign of patriotic propaganda at home to keep up the morale of the Gerian people and the troops. This work had been pat into the hands of the "Kriegs1

The Iiterary Disest, Vol. XIIX; No. 21 (Nov. 21, 1914) p. 1010. Swain, Joseph Ward: Beginning the Twentieth Century, p. 474. 
presseamt", which had also the task of issuing the war news to the German press. This double duty resulted in a failure to organize an effective propaganda system in the satherland, since the "Zriegspresseant" concentrated its efforts mainly on the war news.

The first move in the war of words occurred on Aagast 5. 1914, when the British at the cables between Gernany and the United States, leaving the German government with wireless telegraphy as their only direct means of access to the American publ10. The second move was the censorship of the press of England, and although airected against subversive activities throughout the Enpire, inairectly affected american opinion as American news àispatthes, handled by Lond on newspapers, came under this censorship.

The third move was the censorship of outgoing mail and cables to control information passing between Eur upe and America. Schreiner of the associated Press estimated that at this time (1915) nearly three-quarters of the dispatches written by American correspondents in Central Aurope were perishing under the shears oi the British censors.

1

Bruntz, George G.: Allied Propaganda and the Collapse of the German Emplre in 1918, p. 194. 2

Peterson, op. eit., pp. 4-12. 3

Ibid., p. 13 .

Ibiā, p. 16; see also villis, op. cit., p. 147. 
Ihe first organization for the dissemination of British propaganda was a Neutral Countries Subcommittee, which, though begun on a private basis in Augast 1914, was taken over by the government's Central Committee (Centrel Committee for National Patriotic Organizations) the following month. The method of the subcomittee was as far as possible one of airect personal approach. Haterial was sent out, not in the name of the committee, but in the name of various distinguished Britishers, whose acquaintances, colleagues, fellow worker, or brisiness associates in neutral lands received-- oftent imes unwillingly-- propaganda material prepared and sent by the committee. By this means every possible variety of interests in the neutral countries was reached. Some 250,000 pamphlets, booklets and ot her publications were thus distributed between August 1914 and January $1,1916$. The first official propaganda organization in England for activity elsewhere was the Var Propaganda Bureau, established by the Foreign office in the latter part of 1914. It concerned itself with the distribution of lealets, paiphlets and other material in Allied and neutral countries. This official organization was nothing more than the Neutral Countries Subcommittee under of ficial government sanction and control. The director of the bureau was the Rt. Hon. C. F. Hasterman, and its headquarters were at ilellington House, the office o the National Health Insurance Company. The existence of this committee was unknown to the general public, as it was thought best to attach as little publicity as possible to its operations at home and in Allied 
and neutral countries.

One distingulshed Inglish eopert in this field wrote: "Better than any pumped-in propaganda abroad was the method of making the leaders of the Imperial, neutral or Allied press themselves the propagandists when they returnea home." Not bribery but direct peisonal approach". In Lneland, "American journalists, publicists, auth ors, statesmen, greeters, and munition-makers" were courted assiduously. "Clubs were open to them and teas and dinners were given for them. The Anerican wives of Englishmen, led by Lady Astor, formed a battalion of solicitude lest Ane icans in Ionaon became homesiak." 3 These native American propagandists were volunteers, some being indiviaually enlisted in one cases, but in the main they were regimented into "soldiers of the king" by a process of eliminating, or at least curtailing, enemy interpretations oz the war and by dominating the news with exaggerated and varped pro-klly accounts of what was happening or had happened. Once these Americans had acquired the "correct" Irame of mina, they were "enlisted" for the "duration of the war." The Pormal propaganda groups acted norely as connecting and reInforcing elenents of the British propagana organizations. The

I 2

Bruntz, op. cit., pp. 19-21.

Peterson, op.cit., p. 25 (Lord Beaverbrook, Politioiani and the Press, London, 1927, p. 12).

Ibid., p. 27 (Palmer, Frederick, Jith ivy Own Eyes, p. 332 ). 
real propagandists were the anericans-- our preachers, teachers, politicians and journalists.

The first step in direct action propaganda or censorship to directly effect America occurred just six months before America entered the war, when the few renaining cables were closed to the Hearst newspaper syndicate and their correspondents expelled. This meant that all news apers receiving their foreign news from the Internationa I News service would have to conform to censorsinip or seek a new source of news. Hearst's Iondon representative was instructed to tell him that the prohibition would be effective at once unless Hearst would give his personal assurance that all aispatches would bej printed exactly as received atter passage tnrough the British censorship. When he heard the news Hearst said, "I am going to tell them to go to hell," whereupon the British made good their threat, giving as official grounds "the continued garbling of messages and breach of faith on the part $0:$ the International News Service." Hearst resorted to the pirating of news from a rival press association.

From the partial studies which have been made of German propaganda one thing stands out clearly; it suffered from military control.and ineffective or ganization. Professor Banse, the Nazi military specialist, attributes the superiority of I Ibid., $p .32$. Riegel, Oscar $W_{\bullet}:$ Mobilizing for Chaos, p. 25. 
English propaganda to the fact that it was run by civilians, the German by soldiers. "The latter is the wrong way, because it is not the soldier's but the psychologists' opinion that counts here." H. D. Lasswell contrasts the strong coordination of the British propaganda system in the United States with the minimum of coordinated propaganda effort in Germany, where each department went ahead in its own way, and the only formal cooperation was in the press conference, which met two or three times a week. Others do not agree that the Gernan propaganda machine was defective. Jidney kogerson maintains that "in 1914 Germany was the only power in Europe which had deliberately built up a national propaganda system. She had been at pains to ensure that news favorable to Germany was disseninated in as thoroughly organized a manner as she had organized her army, her navy, and her industry." Will Irwin holds much the same opinion, that German propaganda had the advantage in the early days of the war.

But if one is to follow though on the splendid organization of German industry and military power, we shall discover that this very idea, organization, was skillfully used by British propagandists to undermine American opinion of Germany by making efficiency and organization synonymous with regimentation and

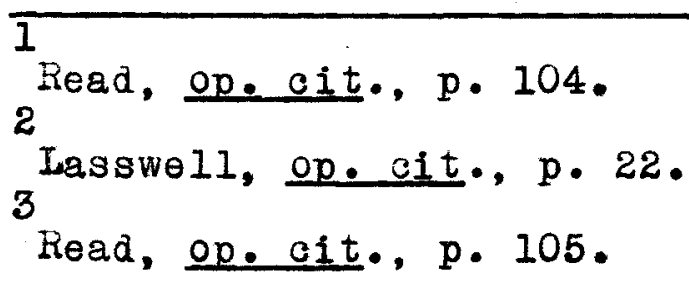


autocracy and in conflict with the Ame rican iaeal of freedom. John Cowper Powys, staff lecturer on Iiterature for Oxford University Extension Delegacy, in his reply to Professor ifunsterberg's writings on German culture, used emotional language to undermine this American opinion of Gerwan organization.

"Let Americans who waver in their allegiance to the cause of the future of the hurnan spirit because of Iunsterberg's talk by 'Cossacks. a nat their Progroms' and English and French with their 'colored races' think of the growth of their own republic. Iet the th think of those great principles of inäiviaual liberty, as against all government-machines, upon which the American la eal is based. Iet them think of Jefferson and of Emerson, of tranklin and of Walt whitman; and let them decide whether they prefer to live in a world dominated by over-drilled and over-bearing 'efficienoy,' or in a world of free, instinctive beauty, and free, instinctive faith!" 2

The Germans, according to the admission of numerous authorities, like George Sylvester Viereck, editor of The Fatherland, were most inept at propaganda. Further evidence of inefficiency is given by Count Von Bernstorf, German ambassador to the

1

Hugo ifunsterberg was a Gernan-American psychologist and philosopher. He was in charge of the psychological laboratory at Harvard from 1892-1895. A few years later he became the head of the department of Philosophy at Harvard. He was the exchange professor from Harvard at the University of Berlin in 1910-1911. Beoame professor of Philosophy of Radcliffe College in 1916. One 2 of the leading German sympathizers in America.

Fowys, John Cowper: The far and Culture, p. 79. 
United States, Count Czerin, the Austrian linister of Foreign Affairs during a part of the war and Taiser Wilhelm himself. Those ohiefly responsible for a isseminating the doctrines of the Central powers in Anerice were Dr. Bernhard Dernberg, formerly Secretary of state for the Colonies, who came officially as the representative of the. Red Cross, and Dr. Heinrich Albert, attached to the Ambassy as Commercial Attache. George sylvester Jiereck, as editor of the Patherland, was already at work before the Gerinan propaganda mane commenced operations through the establishment of the German Information Burean in 1915. With the help of various Gerinans, news releases were sent out to over 500 papers.

In December, 1914, Dr. Willias Bayard Hale, a former clergyman, who had been a journalist for many jears as the literary editor of the New York Times and editor of the Jorld's Work, was eiployed to prepare propagana literature. He was a close friend of Woodrow Vilson. This burea, which never had more than a dozen men in it, took care of the ordinary work of a propaganda organization. It published pamphlets, gave favorable support to authors desiring to publish books which were favorable to Germany, and later arranged for the release of sone newsreels. It was realized, of course, that the newspaper was the most effective propaganda medium in the United States. Consequently, much attention was given to the problem of creating a more sympathetic 1 Abrams, Kay H.: Preachers Present Arms, p. 19. 
attitude in the press. The Germans were appalled by the attitude of smericen newspapers. The few friendly statenents wich were published were naturally unimportant in comparison with the 1lood of articles which were unfriendy. Pro-German colums vere conducted by $\mathrm{H}$. I. Nencicen, in the Baltimore sun, and by Damund von Viach in the Boston Pranscipt. First published in August, 1914, The iatherland was unailuted pro-Germanism. But these were arops in an ocean of pro-klly propaganda.

German propaganda adaressed itself primarily to groups from which it could expect a sympathetic response. It sought the old-fashioned American with hevolutionary traditions; the cotton grower of the south, almo t bankrupted by the blockade; the Irish with a gruage against ingland; the $J \in W$ with a grudge against Kussia; ana last, not least, the German-American. The isolationists wose worla ends with the Rockf fountains lent a wiling ear to the voice of the propagandists. The pacifists, except for those who regarded the Allied enterprise as a "war to end war," clasped hands with the pro-Germans to prevent Unole Sam from increasing the ranks of the belligecents. The radicals cooperated for reasons of their own. Pacifism was the motive of some resentinent against the capitalistic groups, the banks which loaned money to the Allies, and the munition makers whose war babies were skyrocketing in the stock market, influenced others; still others 1

Peterson, op. cit., p. 137 . 2

Viereak, George Sylvester: Spreading Germs of Hate, p. 49. 
were deliberately seduced by bribes. At one time German propagandists in umerica agreed on a mailing list composed of all those listed in "ho's tho in America" in adaition to all members of Congress and the state le gislatures, but this was not carried 2 out. Later, in order to reach the intelligentsia, especially those Ane ricans who had stuadied at Geman Universities, the Germans supported a new organization known as the University League. The aim of the University League was to be a nucleus of Kultur.

The German propa gandists had the cooperation of the German-tmerican flliance, which was well organized in the German strongholds over the nation: St. Louis, Chicago, Cincinnati, and Iilwaukee. There were numerous German social clubs and societies. The Kriegsbund was composed of those who had served in the German army. There were several veterans posts of the war of 1870. The Geneva Society was a specialized organization of German waters. The Turner societies and all sorts of benevolent organizations were thriving in every German district. The Iutheran Church was a strong asset of the Germans, for there were 6,000 congregations in the United States, whose 4 communicants numbered some three million. The American Truth

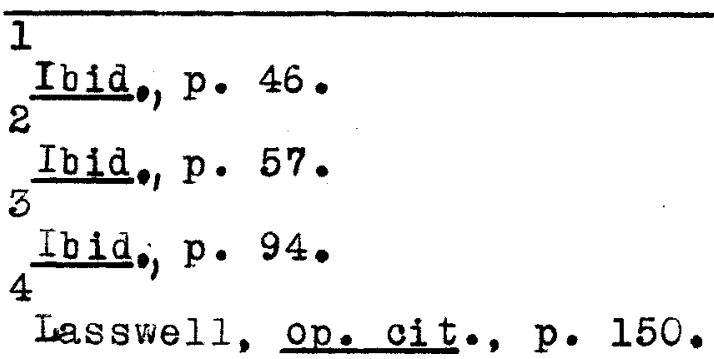


Society, headed by Li. Jeremiah O'Leary, poured forth German propaganda under seeningly domestic auspices. The American Humanity Ieague, the Arne rican Inàependence Union, and many other devotedly pacifistic organizations of dubious parentage were very active. On June 19, 1916, they held a great mass meeting in New York with Mr. Bryan as principal speaker, and with Fepresentative Frank Buchanan, member of the House Committee on Naval Affairs, as another, and with diplonatic representatives of the Central Powers on the platform including Captains Boy-Ld and Von Papen, who were German propagandists. A vast throng ap peared and extra speakers harangued the overflow in the streets. Yet it aid not help the embargo movemente and had anyone learned that it was Cantains Boy- and Von Papen who supplied the funds, it would probably have destroyed it.

The British propaganda on the conduct of the war was mostly based upon the appalling political stupiditles committed by the Geriens. Starting with the invasion of Belgium and ending with the zimerman note, the Cermans committed a series of political blunders which were simply incomparable. New to the field of world power they had little appreciation of the fact that their acts had to be justified by something besides exped1

Franz Von Papen, later German Chancellor and diplomat under 2 Hitler, ac uitted at Nuremburg trials, 1947 . Lillis, op. cit., p. 203. 
iency. In the German attemot to sway american opinion they were hampered by their ignorance of American psychology. Ihis rather than 3ritish cleverness swayed the balance of power towards the side of the Allies in the molaine of dmerican opinion. By judicious editing and rather specialized emphasis these German errors were tamed into veritable acts of frightfulness. The enphasis on the fearful plights of "women and children" characterized ail British propaganda, out vellington House realized that this procedure could reach perfection only if it were made less abstract. The outstanding example of this type work was the feport of the Committee on Alleged German Outrages Which dealt with the Belgian atrocities. Due to the length of the original report it was later condensed into easier reading and in order that "manikind" might have access to it, it was put on sale at the nominal price of one penny. The tragedy of Edith Cavell, when given artistic treatment, came to be the second ranking

1

James Bryce, 1st. V1scount Bryce (1838-1922), English statesman, jurist and author, was chairman of the British cominission to stidy the sturies of German outrages in Belgium and France. The character of the report of the commission (hereinafter referred to as the Bryce keport) helps to explain how inaccuracies and exaggerations so frequently crept into the text. Report itself was a booklet of 60 pages, the sppendix containing the proofs ran to 300 pages. Some 500 depositions were appended to the report, a selection from a total collection of 1,200. Host of the depositions were made by Belgian refugees in ingland, some from allied solaiers and a small number were excerpts from the diaries of verman soldiers. sotually not one clear-cut case of confessed "atrociousness" was in any of them, although many tell of the exection of alleged franc tireurs and more, of plunderings. Read, op. cit., p. 204 . 
atrocity story of the war.

The Germa n submaine warfare also brought the war home to smerica and made it possible for the Allies to claim that this was proof to substantiate their other claims of German barbarity. In spite of all nitigating factor, the sinking, of the Iusitania was the most damaging of all the political errors made by the Germans during the war. It was disastrous to Germany because it was a striking and aramatic event. The spectacle of the innocent passengers mae victims of German puthlessness outweighed any actualities of contrioutory responsibility of the United states, Great Britian ano the Cunard Company, or the dubious correctness of the dinerican policy concerning traveling in the $\operatorname{war}$ zone. It branded Gernany as the malefactor. The entire fie ld of British propaganda was benefitted by this incioent. The most naried advantage was gained with the Ameicans who had been enlisted or arafted as British propaganuists. Whey saw a complete justification of their attitudes. The editors on the Atlantic seavoard lost their heads completely and all found it a type of sensation which sold their newspapers for them.

The arrival of the German subrerine Deutschland at Baltinore in $J u 1 J, 1916$, received much attention in the American 1 2

Peterson, op, cit., p. 51 . Ib1a, pp. 109, 125. 
press-- wich was well divided on the merits of such a mission. Slipoing through the British blockade, the submarine announced itself as being here for the purpose or taking on bady needed supplies for the German governinent, but one can also inagrine that it was here for propaganda purposes as the pay load of a submarine is very little even when compsed with the snallest freighter. The Baltimore Anerican believed that the incident was the beginning of "a new era in the world's marine history," and the Boston Journal declared it "man's greatest single viciory over the sea." Other newspapers that could see value in the mission included the New York Globe which stated, "a pioneer, a me rchant boat pure and simple," while the Hew Haven Journal-Courier bel ieved the incident would aid the tion in remaing neutral.

sut other representatives of the Anerican press felt differenty. The Brooklyn Eagle asked, "zepplins next?" while the Springfield Union believed the incident would "avail them little," and the New York Sun considered it of lit tlo importance. The Pittsburgh Chronicle-Telegraph stated ironically, "The Deutschland will carry at least 1,400 tons of nickel and rubber for the starving babies of Germany." The general sumary of the press, towards the incident, proved that a slight majority of American papers commenting on the incident, had already made up their mind as to whom they were supporting. German propaganda had a huge I

Lit. Dig. LIII; 4, (July 22, 1916) p. 169. 
obstacle to overoome.

Eren the retaliation of the British government, the blaoklisting of American firms which had supplied the Dentsohland. found mach sapport in the press. The Brooklyn Eagle remained oonsistent in its stand, calling the British action, "justifiable" while the Journal of Commerce, a spokesman for American moneied interests, belleved that the firms were "ran and controlled from Berlin." Fighting for what the $y$ considered the law of the sea and the rights of nations were the New York Evening Maid whioh considered the aotion as "violating a fandamental of international law" and the New York. World whioh believed that "Brita in was inviting retaliation." The German language papers fought the British with a huge flow of words, bat to little avail.

Whether the German government discovered that their friendy visits to America were not having the desired effects and decided to ohange their policy is uncertain bat on the morning of October 9, 1916, the American public was amazed to read that the U-53 commanded by Captain Hans Rose had penetrated the waters of Narragangett Bay and had sunk five ships almost with in sight of the coast. Two of the ships belonged to neatral powers, Holland and Norway. This was the only effort of Germany to invade American waters. If this act was intended to scare America out of entering the war, it had bad psychological direction, for in1

Iit. Dig., LIII; 5 (July 29, 1916) p. 235. 
stead of keeping America out of the war it proved to many the 1 danger of German seapower. The Ner York Evening Post stated, "in quarters olose to the Administration the extensi on of the German submarine oampaign to the Atlantio seaboard of the United States is regarded as constituting the gravest menace to the maintenance of good relations between the two countries which has appeared since the sinking of the Iusitania."

Not only did the Germans commit political blunders, the $y$ also failed in the first step of opinion formulation, that of meeting the public on the pablic's level. Ambassador Bernstorff complained of the inadequacy of the material sent to America from Berlin:

"The Press-service never succeeded in adapting itself to American requirements. The same may be said of most of the lerman propaganda which reached America in fairly large quntities since the third month of the war, partiy in German and partiy in not a lwajs irreproachable English. This, like the Press telegrams, showed a complete lack of understanding of american national psychology. The outstanding characteristic of the Average American is rather a great, even though saperficial, sentimentality. There is now news for which a way cannot be guaranted through the whole country, if clothed in sentimental form." 3

Another mistake of the German a uthorities was in never

$\overline{1}$

Allen, George H. and others: The Great War, Vol. 4, p. 428. 2 Iit, Dig., IIII, 17 (October 21, 1916) p. 1015. Lasswell, op. cit., p. 34 (Bernstorff, My Three Years in Ameri08, p. 53 . 
fully appreoiating the absolute necsity of counter-acting anti-German feeling in the new world. Propagama was anderestimated too long, the organizations which were handing it were inadequate, and the material issued was never sufficient. Upon his return to Germany. Von Papen reported to General Falkenhayn:

"General, if jou do not sacceed in keeping the United States from joining the coalition of our enemies, you will lose the war; on this ppint there can be absolutely no doubt. The enormons material and moral resources at the disposal of the United States are so wholly underestimated here that in my opinion it is above all things essential to enlighten pablic opinion to an extent quite different from that which has hitherto been the case." I

The Berlin authorities realized the problem and attempted to rectify their mistakes. In 1916 a syndicate dominated by Dr. E. A. Ramely bought the New York Evening Mai 1. Unsuccessfal attempts were also made through Samuel. Untermejer to purohase the New York Sun. The Internationsl, a monthly magazine of literature and comment, was bought in 1915. It, however, tarned out to be an unsatisfactory investment. There is some suspicion that the Jewish paper, Die Wahrheit was finanoed with German funds. The most successful of the investments was the Fatherland, a weekly magazine edited by Viereck, but little was achieved by these efforts. The almost unanimons opposition of the American press could not be overcome.

1 2

Peterson, op. cit., p. 124 .

Ibid., p. 139; for further information, see, Pearson, Drew: Weshingt on Merry-Go-Round, June 12, 1948, The Clarksburg TeleEram, Clarksbarg, West Virgi nia, p. 7 . 
But despite their bad start, the German authorities did learn one lesson-- by 1916 there were few political blunders. The British also found it impossible to arouse ang new indignation over German activities in the United States, since the propaganda and sabotage work of the latter had been practically eliminated. The Germans also took advantage of a new method of transmission, the radio, and sent full reports of American correspondents in Berlin and on the German fronts.

The Germans on the field of battle were also beginning to supply counter-propaganda by stopping the Allied victory arive which had been foretold with reams of words. The best the British could now do was to boast that the Germans had not defeated them. The first big German campaign in America was to defeat the initial loan to the Allies and the pro-Germans adopted the picturesque device of having sandwich men parade in front of $\mathrm{Mr}$. Morgan's office, warning against the loan. German-Amerioans threatened to boyoott banks and insurance companies investing in the ang 10-French loan. In several cities, especially Milwakee, this agitation, aided by the National German-American Alliance, by the Amerioan Truth Society and others, seriously interfered with the handing of the bonds. However, the very fact that the proGermang took such an aotive part in the campaign against the loan 1 2 Peterson, op.cit., p. 242 . 
intensified the activites of the pro-Allies in its favor.

An attempt to influence Congressional action involved the program of the Embargo Conference which was organized by the German propaganda barean to bring a halt to the shipping of manitions. About 250,000 messages were sent to Congress and J. J. Tobias, of the Friends of Peace; a kindred organization, emphasized this threat by stating pablicly that five million Toatonio voters were going to "raise hell" with any party not in favor of 2 this proposed embargo.

One of the most subtle forms of propaganda and also a new idea in propaganda was the use of motion pictures among foreign-born munition workers. The picture financed by the AustroHungarian government showed Austro-Hangarian workmen making shells which might kill their relatives on the other side of the ocean. In one soene the munition factory burns down. The fire is attributed to a rival manufacturer, but the suggestion is obvious. However, $\frac{}{3}$ no sentimental appeal could compete successfully with high wages.

The Germans, first to use atrocity stories, failed to 4 propagate them successfully. The German authroities were quick to

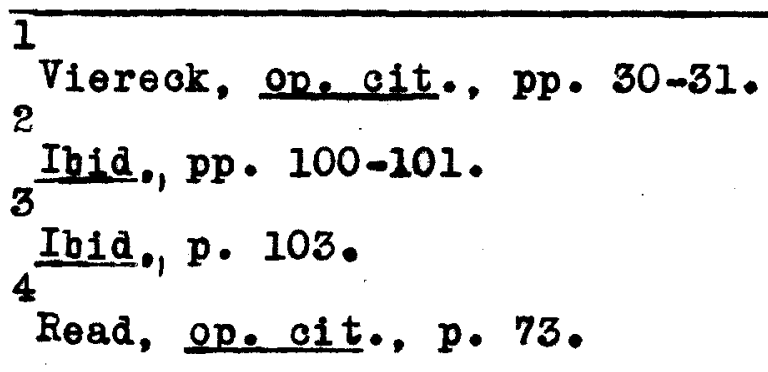


publish official reports establishing the "facts" of atrocities and andoubtedly convinced the German people, but they could not keep paoe with the Allies in the battle for pablic opinion throughout the world. A major weakness in their tactics was the exoessive time and energy they used in defending themselves against allied atrocity oharges; if the items on defense of atrocities in the German press were veighed against those on charges of atrocities, the former would probably predominate. The Allies, on the other hand, paid little if any attention to the German charges. Another weakness of German propaganda lay in the work of the official agencies. Atrocity reports were pablished by governmental departments and lacked the prestige acoruing to the reports of Bryoe in England or of the appointed commissions in France and Belgium, on which noted jurists and professors served. A third failing of the German atrocity propaganda was the absence of pamphlets and artioles detailing the enemy crimes. The official reports were all large and unwieldy, completely unfitted for popalar distribution and consumption. A fourth defect was the failure to translate them into the English language. Some of this was done, but very little compared with the flood of German atrocities released by the Allies. Of course the atrocity propaganda suffered, like all German propaganda, from the Allied control of the oables and news channels throughout most of the world. Still, much more could have been done in the ciroulation of pamphlets and brochures. The German propaganda bureau did make one strong appeal to the American public which had favorabie results. This was the 
German discussion of British interference with Amerioan trade and malls. It was successful becane it dealt with something of importance to the United States. Thus for once the Germans utilized the British practioe of dwelling on community of interests, and for a moment convinced the dmerican people that their desires were identical with those of Germany. The only other really successful German propaganda was that directed against the export of manitions. This was kept up over a considerable length of time and Americans agreed that the munitions trade was not righteous. The Germans failed to talk of sensations. They philosophized and ex1 pected the people to listen to reason.

The work of the German propaganda burea was also hampered by official United States government representatives, with the stealing of $\mathrm{Dr}$. Albert's portfolio in July, 1915, the prime example. The American explanation of the mystery of the porloined portfolio is furnished by W. H. Hought on of the United States Secret Service, in the Saturday Evening Post. An agent named Frank Burke was shadowing Dr. Albert on orders, saw him leave the portfolio and immediately picked it up. Whatever the facts in the portfolio mystery were; the Albert brief case was immediately turned over to President Wilson. The President entrusted the hornet's nest to Colonel House and photostatic copies found their way into the office of the New York World. The publication of the Albert papers was a German oatastrophe. It dramatized German I Peterson, op. cit., pp. 141-142. 
propaganda. Henceforth the Allied propagandists could go as far as they liked. The stamp of propaganda was fastened apon the 1 Germans.

Other governmental interference was the tapping of telephone lines from the German embassy and the recording of every telephone message from the German embassy to the outside world. The conversations between Embassy officials and their friends in New York were spiced with uncomplimentary references to high personages in the White House and the State Department.

German activities in the United States were in themselves of no great importance in accomplishing the objectives for which they had been designed. The propaganda convinced few people who were not already adherents of the German cause; purchases were too small to make ang great difference to the oconomlo warfare of the Central Powers; the sabotage only delayed-- it did not stop the supplying of war materials to the Allies. These German operations were of consequence in that they gave British propagandists hor rible examples in America which served to illustrate dramatically that the Germans were America's enemies and they were as evil as they had been plotured. The true signifioance of the German activities in the history of this period lies in the faot that the pablicity given to them a ugmented greatly the

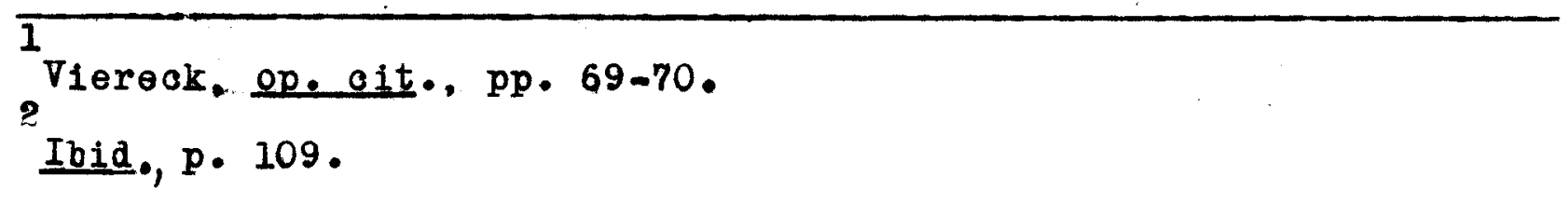


1

anti-German feeling among the American people. Suffice it to say that the Amerioan people got the idea that the German pe ople and the German government were two separate things, and that the German government was a menace to the world. The German propaganda, none too well received at first, was rained further in its effectiveness by the sinking of the Lusitania. Minor misfortunes rocked the boat, but did not destroy it. The German propaganda oraft was wrecked by German torpedoes. Whenever the propagandists had succeeded in inveigling public opinion against Allied aggressions, bang: -- another American ship would be blown up by a submarine. The New Republic oarried this idea to the extreme when it stated, ".... the German government cannot and does not care to understand the democratic view of the war." ${ }^{3}$ The finishing crash came with the exposure of the Zimmerman note-. "Wo cannot," said Viereok, "remain the friends of a country that is plotting to destory our owh."

In the House of Commons twenty years after the war some straightforward comments on British propaganda were delivered by Mr. Harold Nicolson, ex-diplomat:

n.... I do not want to be selfrighteous, because in a national emer-

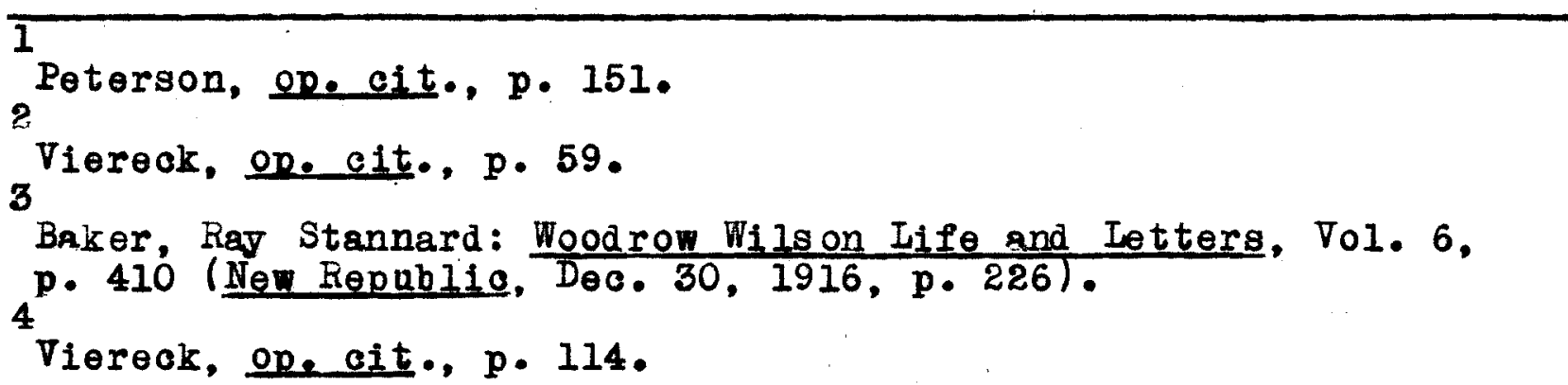


genoy we can be as untruthful as, or more untruthful than, anybody else. During the war we lied damnably. Let as be olear about that. (An Honorable Member: Splendidly? ) No, damnably, not splendidly. I think some of our lies have done us tremendous harm and I should not myself like to see such propaganda again." 1

Much of the British atrooity propaganda was deliberate deoeption bailt upon erroneous reports and misleading impressions. The facts were Irequently auestionable, the interpretations misleading, and it was this kind of propagande that $\mathrm{Mr}$. Nicolson deplored. Nevertheless much of it was spread by people who sincerely believed what they were saying; their faith only added potenoy to the propaganda. The best British propaganda was truth-a not necesaarily the whole truth.

The British propagandists in carrying out their work followed certain general lines which might be oalled techniques. In part they were as follows: 1. They told only that part of the truth which benefitted their cause; 2 . They utilized background material to imply things for which there was no evidence; 3 . They exploited to the fallest the emotions and ideals of those being educated; 4. They gave their propaganda an aura of authority by asing big names, by quoting their enemy, or by appealing to legality: 5. They made the ir arguments simple and eliminated all

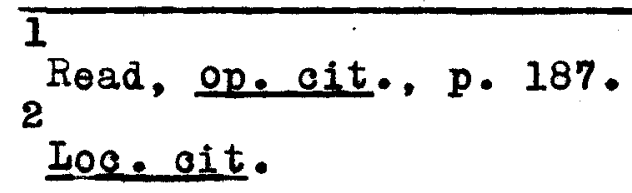


qualifying statements; 6 . They ased endess repetition.

There were a number of factors which contributed to the great success of Sir Gilbert Parker and his associates. In the first place, there was a pro-British attitude among leading Americans at the outbreak of hostilities. Secondly, the ir propaganda was unobtrusive. Viereok quoting a British propagandist stated: "We spoke your language. Our men merged wi th the crowd. They passed as Americans. In ever newspaper office, in every great industrial concern, there were Englishmen whose national origin no one spepected or questioned." In the third place, their principal onemy was a new riaing nation with all the unpleasant characteristics nominally encountered in the newly rich and newly powerful. Finally, their control of the conventional channels of American opinion made it unneoessary for them to compete on an equal footing with the Germans. Sir Gilbert Parker admitted to the last of these reas ons:
"Among other things, we supplied three hundred and sixty newspapers in the smaller states of the United States with an English newspaper which gave a weekly review and comment on the affairs of the war. We estab- lished connection with the man in the street through o inema pictures of the army and nary, as well as through interviews, articles pamphlets, etc.... We advised and stimulated many people to write articles.... we had re-

\footnotetext{
$\overline{1}$

Peterson, op. ait., p. 36 . 2 3

Viereck, op. cit., p. 122 .

Peterson, op. cit., p. 33 .
} 
ports from important Americans constant-

Iy, and established assooiation by per-

sonal corresp ondence with influential

and eminent people of every profession

in the United States." 1

"Practically since the day war broke out," was Sir

Gilbert's cheerful remark, "I was responsible for Amerioan pablicity :"

The Allied Propaganda, moreover, enjoyed the inestimable advantage of being self-financing. Our pablic olamored for the books, articles and motion-pictures films whioh conveyed it. Old established American pablishing houses found it profitable, and did not think it unpatriotic, to enter into agreements with the Entente governments for the distribution of propagandist war books, and there was a huge trade in volumes on trenoh life from the French and British standpoint. Those who voiced the German side of the case found no such markets. The German representatives in the United States had to give financial assistance to the ir outlets.

One of the lessons to be drawn from the success of British propaganda in the United States is the importance of perI

Slosson, Preston William: A History of American Life, Vol. XII "The Great Crasade and After, 1914-1928", p. 9, TSir Gilbert Parker: The Unjted Stateg and War, Harpe'r' Magazine, CXXXVI $(1918)$, p. 552)

2 3

Millis, on, oit., p. 63.

Ibid., p. 202 . 
sons as means of carrying suggestion. The powers behind the impersonal agencies must be reached, and this is best managed by personal contact.

The most nearly perfect example of the British propaganda burear taking advantage of sensations to attract the attention of the American pablic, concerned the famous Bryoe report. Perhaps it was only a coincident that on the same day that the American public was notified of the sinking of the Insitania, when the boiling indignation against Germany was at its height, that this report was dropped into the maelstrom. The Belgian atrocities, if not precisely forgotten, had beon sinking into the baokground under the weight of an accumulating skepticism. The whole thing had been rather overdone. But with the Bryce report, pablished at just that emotional moment, every doubt was obliterated. There was no name in England which could have inspired more confidence in an American publio that that of Iord Bryce; his six colleagues were only less impressive. "Proof," cried the New York Times, "now comes to hand."

The Reasons for the effectiveness of the Allied propaganda may be summed ap. in the words of an impartial historian, Carlton J. H. Hayes:

"Entente propaganda in the United

1

Lasswe11, op.cit. pp. 212-213. 2. Millis, op. cit., p. 183. 
States was even more general than that of the Teatons; it was also more adroit, more sympathetic, and more conformable to American prejudices and American wishes."

$-0-$

$\overline{1}$

Abrams, on, cit., p. 19 . 
III. THE REACTION OF THE AMERICAN PRESS,

A newspaper is a private enterprise, owing nothing to the pub1io, which grants it no franchise. It is, therefore, "affected" with no publio interest. It is emphatically the property of its owner who is seling a manufactured product at his own risk.

WaIl Street Journal 
The newspaper field must not be overlooked in attempting to sift out the course of public opinion during the period of our neutrality, prior to the entrance of the United States into the First World War. During this period the daily journals comprised approximately ninety per cent of the reading material of the American public and, although we have no hard and fast proof for the belief, we feel that they were bound to have influenced the forming of many opinions. To the everyday reader, interested in the nation's welfare, the newspaper provided the doings and sayitof the world, and the people as a whole/ might have said/with a famous umerican, "All I know is what I read in the newspapers."

Training in how to read the newspapers, knowing what diffioulties in their compilation to allow for, detecting prejudice, supplementing daily news in the longer discussions to be found in magazines, are all part of the foundation of intelligent citizenship. The newspaper has its own task and funotion. There is no justification in king it, as it were, the scapegoat for failures of the community conscience. Yet newspapers are powerfol weapons. Individual papers have been important if not the decisive influenee on different ocoasions in actualy bringing about a war and in preventing wars.

1

Iibby, C. F. : The Press and World Peace, (The Causes of War), p. 182 . 
All the reporters in the world working all the hours of the day could not witness all the happenings in the world. Newspapers do not try to zeep an eye on all mankind-- just oertain spots. This makes the press agent or publicity man a valuable person who can present.these spots in the most favorable or unfavorable light. Thus every organization with a desire to express an opinion becomes a wedge in placing its story in 1

the paper. Newspapermen have a feeling for words and moods and they know that the pablic. is not convinced by logic, but seduced by stories.

The swift interchange of threats among the Great Powers in the last week of July and the outbreak of hostilities in August brought the European crisis to the American front page. The Her York Times in pertiomlar distinguished itself by printing in full the official British correspondence, running to more than a handred documents, as soon as the British government made it available. From the outbreak of the war until the entrance of the United States made necessary a sort of military censorship, the Amerioan press continuously laid before its readers the fullest account of corrent events which could then 1 Iippman, op. oit., pp. 338, 345, 377 . 2

Lasswell, op, cit., p. 32 . 
be obtalned anywhere in the world.

The general reaction of the Amerioan press to the European blood-bath was a "Thank God for the Atlantio Ooean." The Chicago Herald proposed a rising vote of thanks to Christopher Columbus. The New York Evening Pogt poured its contempt apon the three continental emperors, Francis Joseph of AustrisHungary, Nicholas of Russia, and William of Germany-- "one of them senile, another subjeot to melancholia, and a third often showing signs of a disturbed mental balance"-- who had given the signal for the holocaust. "Our isolated position and freedom from entangling alliances," the Iiterary Digest sammed ap. "inspire our press with the oheering assurance that we are in no peril of being drawn into the European quarrel." American sympathies were divided, but opinion was united in the belief that the United States could never be other than a spectator. As many editors looked upon the situation they began to visualize incidents that might affect them in days to come. The St. Louig Republic stated, "As the shook of the present experience passes amay the oapital of the world will be invested in such quantities as never before in the industrial and commercial enterprises of a country 4,000 miles from the orossed

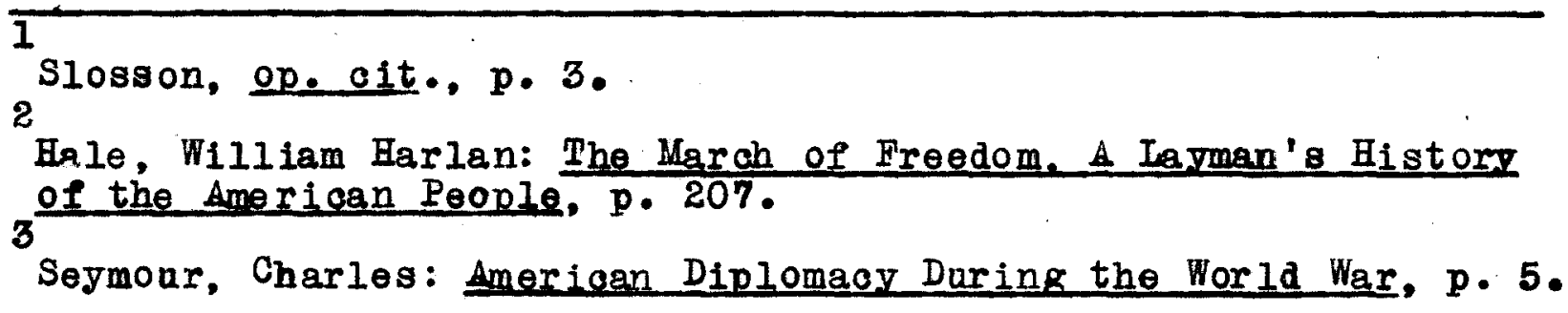

Hale, William Harlan: The March of Freedom. A Latman's History of the American People, p. 207.

Sejmour, Charles: Amerioan Diplomacy During the World War, p. 5. 
bayonets of Europe." The New York Commeraial surreyed the soene stating, "If England can keep control of the seas our trade in breadstuffs and meats will be enormous and highly profitable, because Russia, the ohief wheat grower of the world, will be shut in and the grain crops of the ralley of the Danube will be practically destroyed." The New York Journal of Commerce Viewed the situation differently, feeling that "higher prices for clothing because of wool imports shat off will be necessary and the same for rubber, copper and tin," while the Sun believed that the supply of women's fashions from Paris would be shut 1 off.

On the other hand there was a widespread tendenoy on the part of the American press to hold Germany and her ruler largely responsible for the war. The New York Globe believed that "it is difficult to admit that Gorman interests were menaced beyond reasonable tolerance.... American opinion is almost solidly arrayed against Germany as the aggressor, ruthlessiy planging Europe into what looks like the bloodiest of wars to satis the overwhelming ambiti on of the Emperor." But the New York Herald felt differently, believing that "the Kaiser up to the very last moment almost went down on his knees to Russia to ind ace her to desist from mobilization." The staid 1

2 Iit. Dig., XIIX, 7 (Aug. 15, 1914) pp. 256-257. Ibid., p. 254 . 
Timeg also believed the conflict was the "least justified of all wars since man emerged from barbarism....", seeing the Kaiser as the aggressor. The Springfield Republican bending backwards to remain neutral "supposed" a parallel to Austria's case: "Suppose Texas filled with rebellions Mexicans anxious to secede to Mexioo, and a President of the United States Assassinated by a Texan affiliated with the Mexicans." But the Iiterary Digest expressed the common opinion "that while our trade will be stimulated, we $\frac{11}{3}$ erentually share in the economic loss of such a disaster."

From a sarvey of the Amerioan press at the beginning of hostilities it appeared that, out of a total of 367 editors, 105 admitted favor for the Allies and 20 for the German cause, the other 242 disavowing any preference. The feeling of the communities represented was given as pro-Ally in 189 cases, pro-German in 38, divided in 140. One might also feel that the editors were no different in chooging their favorite than the members of the community-- only more cautious in expressing an opinion. The expression of war-time sentiment was partly sectiona 1. In both cases the Hidale West was more pro-German than the Erst, the Far West or the South. The evaluation of the 1

Iit. Dig., XIIX, 6 (Aug. 8, 1914) p. 215. 2

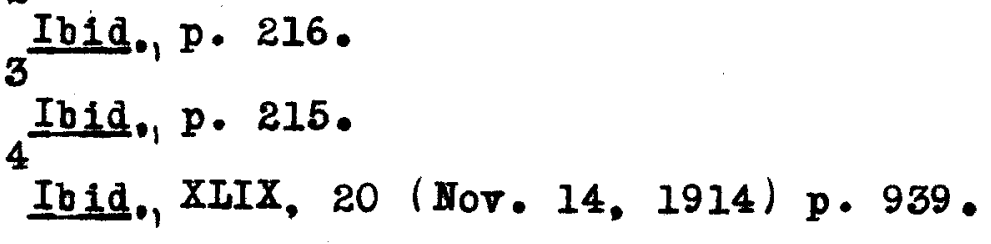


midwest was probably wong with the pollsters mistaking neatrality for partisanship or taking the isolated instances of German-American citizens in Chicago and Milwakee as representing the entire section. Sharp comment by eastern newspapers on the "paoifism" of the midwest provoked a corresponding sensitivity, an exchange which brought an amusing sequel, when, after the United States entered the war, western editors could show that recruiting proceeded most rapidy in the "pacifist" states.

Some persons arged from the start that the causes of democracy and oivilization were so elosely bound up with the fortunes of the Entente nations that it was the moral daty of the United States to join these powers in arms. Bat the country as a hole saw no possible course save neutrality, a polioy dictated alike by present interest and by a century and a quarter of consistent practice. August 4, when five nations had entered the war, President Wils on issued a formal proclamation of neutrality, which was repeated as successive states entered the contest; and two weeks later he made a special appeal to his fellowaitizens to be "neatral in fact as well as in name.... We must be impartial in thought as well as in aotion.... ${ }^{2}$ Wilson re1

Iit. Dig., IIV, 11 (May 19, 1917) p. 1486.

Ogg, Frederio Austin: The American Nation: A History, Vol. 27, Nationsl Progress, p. 329 . 
auested this "impartiality", fearing hyphenated influences when official neutrality was the obvious polieg. Our foreign relations were based upon a theory or tradition of isolation, but economically we.were entangled vitally in every part of the world. The government could assert its determined neutrality, for it had little politically at stake; bat could American industry and finance be kept ne utral? The Iew York Times immediately reiterated the stand taken by the President stating. "It is a source of great comfort and satisfaction to feel that in such a time as this we have a President who knows so well how to do and say the right thing," and on Ootober 16 they praised him again believing that President Wilson "has taken the exact stand and has expressed it with admirable accuracy $" n$ Henry Watterson, in his own mind separating the German people from the German government, was anything but impartial to the government, as he wrote in the Louisville Courier-Journal, "May Heaven protect the Vaterland from contamination and give the German people a chance! To Hell with the Hohenzollerns and the Hapsbargs."

In general, it may be said that throughout the nation the people listened to Wils on's proclamation of neatrality with great respect and probably intended to carry it out to the letter. But a sustained neatrality under the ciroumstances was too much

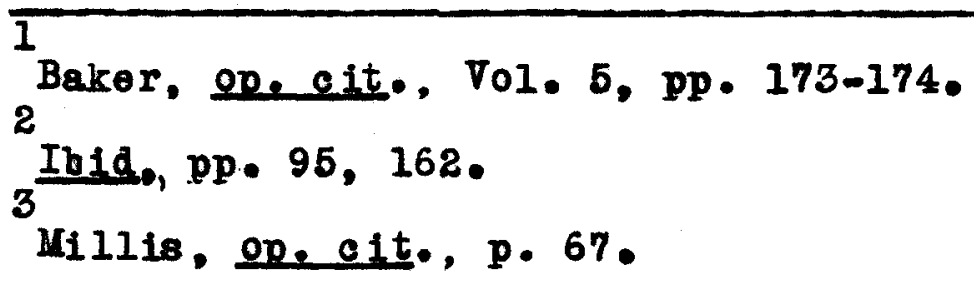


to expect. "Morally neatral the country never was," asserted John Dewey, "and probably the only stapld thing President Wilson did was to suppose, in his early proolamation, that it could be." Another minor criticism of the President came from the New York Timea, just four days after they had praised his stand. The staid Timeg believed that the President's "scholarly surround ings" persuaded him to take "too kindly a viev of the good Intentions of foreign nations. ${ }^{2}$

With the German invasion of Belgiam the American press was suddenly flooded with atrocity stories. An answer to many of them came from a group of Amerioan newspapermen in Belgium who had been orertaken by the German adrance and had continued thereafter with the German armies. Early in September a band le of Allied and ne utral newspapers fell into their hands; they were astounded and shocked by what they read concerning the operations they had just been vitnessing. Harry Hansen, Irvin Cobb, John T. MoCatoheon, Roger Lowis and O'Donnell Bennett dispatched a joint cable to the Assooiated Press:

"In spirit fairness we unite in deolaring German atrocities ground less as far as we were able to observe. After spending two weoks with verman army accompanying troops upward handred miles we unable report single instance unprovoked reprisal.

1

Abrams, op, cit., p. 21. (John Dewey, Amerioan philosopher and 2 educat or and long-time Columbia University professor.)

Baker, one cit.. Vol. 5, p. 180. 
Also unable confim rumors proved groundless.... Disoipline verman soldiers excellent as observed. Ho drankeikness. To trath these statements we pledge profess lonal personal word." 1

Moreover, the American consul-General at Antwerp telegraphed the State Department that positively no bodily harm had come to Belgian women and children in that city, although the preoipitate execation of the expulsion order might have worked hardships on some of them. "In times like these, stories of terrible atrocities will crop out everywhere but let Americans keep cool and remember audiatur et altera parg." (the other party mast also be given a hearing.) The State Depertment immediately answered Consul General Diederich informing him that "Our neutrality does not permit an expression of opinion by our diplomatic or consalar officers." ${ }^{2}$ This State Department message might have been the extreme form of no utrality or the first hint that the Allies were our "secret ohampion" in the Eur opean straggle. Herbert Hoover, head of the Belgian helief Commission, sammed up the case of the Belgian deportations:

It is our belief that the bratality of the operation was largely the fault of the local commandants and lack of adequate arrangements for the reception and distribation of the eracues. We do not believe any suok bratalities were comitted with intent of high authorities. We believe they

\footnotetext{
I Millis, op.eit., p. 68 . 2

Read, on. cit., p. 45.
} 
honest iy and expeditionsly corrected the matter as far as they were able when it came to their attention, and we are informed that disoiplinary measures were taken. We do not believe the storles of rape, or concubinage, eto., spread in the propagandist press.

The incident is one of sufficient ly terrible order, bat as things go in this war it has resulted in less ro lame of human suffering than many other continuing barberities in Europe." 1

"There has been nothing in the history of the German race," declared the St. Loais Globe-Democret, "to lend credibility to stories of such atrocities." ${ }^{2}$ The Milwankee Free-Press, printed in a distinctly Geman-American district, protested against the "unfair and insincere" emphasis whioh our newspapers and magazines had laid upon the atrocity charges againgt Germany. It pondered "what these same publications would be doing if the rrench and English, or the Russians, were fighting on German so11, if they were besieging and taking German cities. 'Ihe same destruction would be their lot...."

The first break in pro-Ally sentiment occurred in late September, 1914, when England, fighting desperate ly to halt the German war machine, began to halt American ships for searching. The Wall Street Journal, from the predominantly pro-Allied east, could find no fault in the action. "A conduct

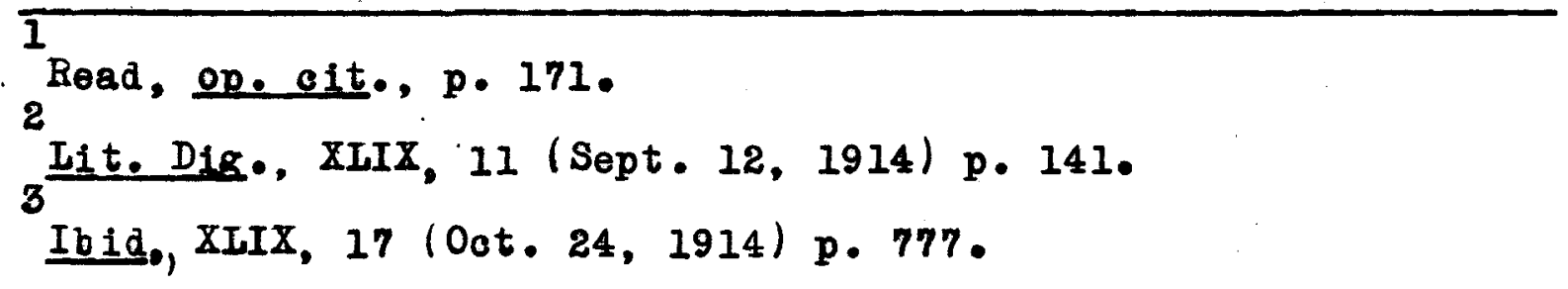


friendy and impartial dos not mike it the daty of the gorvernment to prevent its citizens from trading with any of the belligerent powers.... The risk is his own.... the loading and clearing from port." ${ }^{1}$ But a week later when three American tankers/headed for Denmark were halted, some of the American reaction was violent. "A fow more acts of piracy of this British kind," stated the New York Felegraph, "will force the American navy int o action." But the New York Journal of Commerce talked calmness and felt "that there is nothing to get excited about." Complaining bitterly of the go-easy poliog of the government, the Brooklyn bigle remarked that "wo need not expect any display of volcanic ind ignation from Washington." The ships were later released following an official government protest.

On December 8, 1914, speaking to Congress, President Wilson stated that provision for voluntary military training should be extended, and that the organized militia of the states should be "dereloped and strengthened." The war in Earope had called attention to the small size of our army and here began an agitation for "preparedness." Wilson refused to become alarmed, saggesting merely improvement of the militia.

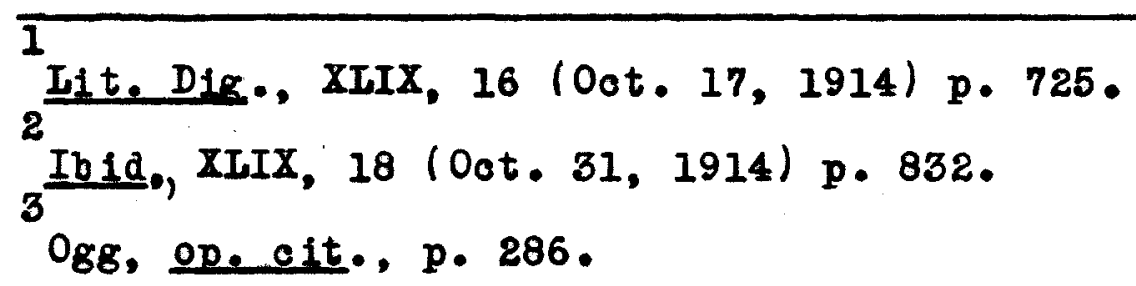


The call for." "preparedness" found the editars of the Literary Digest placing an opinion poll before American newspaper editors, requesting information as to what size our Army and Nary should bo. Three qustions were agked: 1. Are our national defenses adequate?; 2. Do you favor a stronger standing a rmy?: 3. Do you favor a stronger standing navy?

The newspapers partici pating gave a slight edge to the preparedness plan. Two hundred and seventy-five felt that our defenses were inadequate with 119 believing them safficient. Two hundred and forty felt that a larger army was necessary with 158 opposed and 285 favored a larger navy with 109 opposed. The Buffalo Timeg went so far as to state that "ther conld see a Jellow peril arising," but the idea of Germany as a potential enemy was not mentioned.

The following month another poll was taken, this time concerning the prohibiting of arms and ammunition to warring nations, as a means of halting the struggle and also of assuring our neutrality. Four hundred and forty newspapers replied with 224 stating "no,".167 favoring the prohibiting and 29 being noncommital. 'the answers from cities of 50,000 or orer favored the selling of weapons of war and the smaller towns asked for prohibition by a small majority. The Digegt stated "their votes

\footnotetext{
Iit. Dig., I, $4(\operatorname{Jan} .23,1915)$ p. 137.
} 
were backed by hundreds of reasons of all sorts." ${ }^{1}$

A boiled-down version of American opinion in the early part of 1915, if the Iiterary Digest poll was accurate, seemed to show the general public for preparedness in case the program of ne utrality failed. But also with the new year came the submarine wan that brought the European straggle closer to the American fireside and was later to cause a general swing away from our neutral policy. The first American citizen to die from the ifrect resalt of , verman torpedoes was on the British liner Falabs. The editorial pages roared out their def1ance of the act. "A crime against humanity," stated the Philadelphia Public Ledger and the New York Herald-Tribune labeled it "an assassination." The Journal of Commerce believed it "an atrocity against which the civilized world should protest with one voice," and the New York Post condemned it with one word: "piracy." The Washington Post calling for the pablic to remain calm, adopted a middle-of-the-road attitude and believed the action as bad for 2 one side as the other. Comment from the South and West on this incident was not carried by the Digest, in this or subsequent issues.

It was on Maj 1, that the Lngitanie eased out of her berth in New York and began her last tragic voyage to Earope. $\overline{1}$ Iit. Dig., I, $6(\mathrm{Feb}, 6,1915)$ p. 225.
Ibid, I, $15(\operatorname{Apri} 110,1915)$ p. 789. 
"Sa1ls, Und isturbed by German warning," declared the Times in a Iront page column. The passengers who were aboard could not credit the extremes of ferocity to which madened nations could descend. They even commented lightly on the warning as "silly, tommy-roc." ${ }^{1}$ But Friday, May 7, 124 American lives were lost with the Insitanie off the Irish coast.

The following day the morning papers were shouting the news in bigger and blacker headines than they had used since the early days of the war, an their editorial pages were blazing with horror and indignation. "From our Department of State," cried the New York Times, "there mast go to the Imperial Gorernment at Berlin a demand that the Germans shall no longer make war like savages drank with blood." The Tribane closed its philippic with an appeal to a moting passage in our history: "The nation which remembered the sailors of the Maine will not forget the civilians of the Lasitania!" Theodore Roosevelt leaped shout ing into print; "This represents not merely piracy but piraoy on a vaster scale of murder than old-time pirates ever practiced." From the violently pro-Ally Northeast the great wave of shock, outrage and denanciation spread throughout the newspapers, at least, of every part of the country. Only two English-language papers in the United States-- one in St. Louis and the other in I

Bake r, on. cit., Vol. 5, p. 323. 
Milmaukee-- could be found defending the sinking. Ihe Memphis Commercial-Appeal was ready "to consider a declaration of war." From Loaisville the roice of Henry Watterson thundered in vivid imagery:

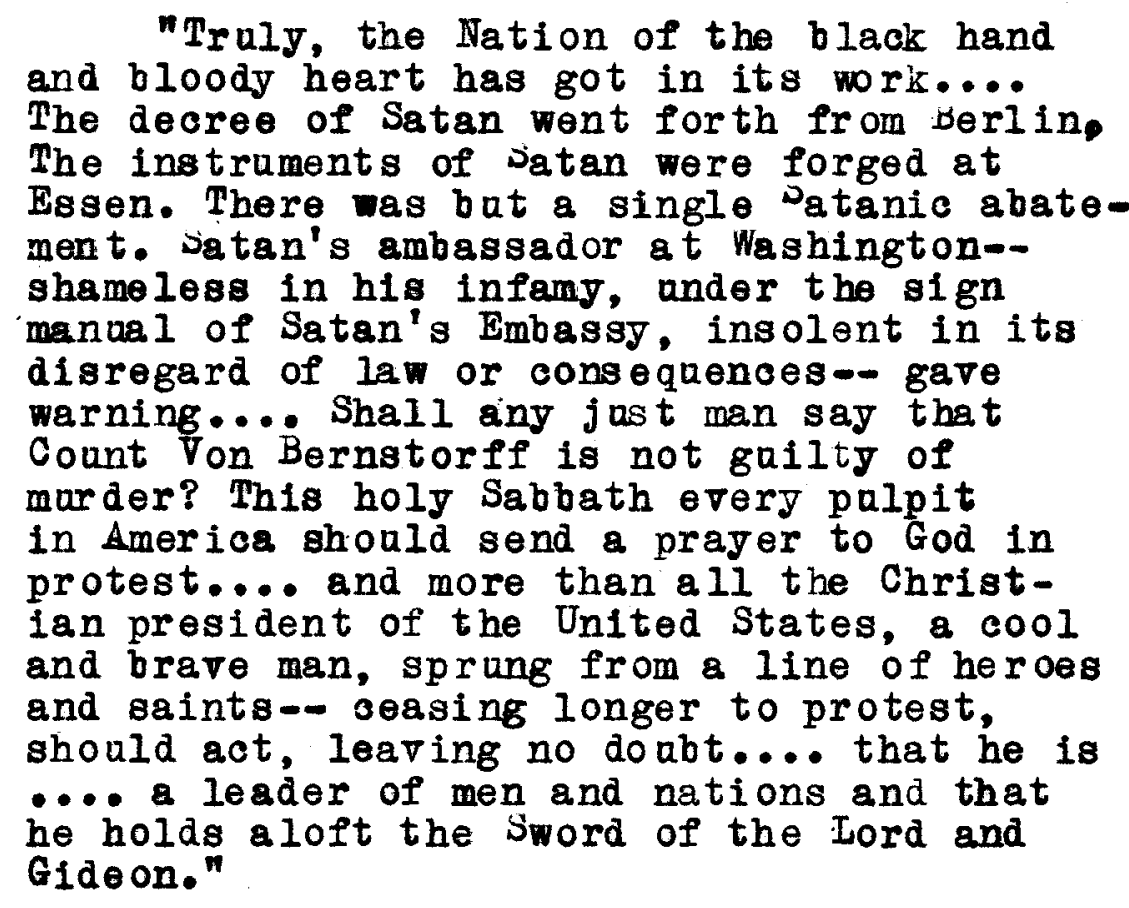

"Condemnation of the act," as the editors of the Iiterary Digest were forced to leave it, "seems to be limited only by the restrictions of the English language." The language had hardly given out before the pencils of the cartoonists were reinforcing it with every kind of stirring and terrible visual appeal. The preachers sprang to follow Marse Henry's advioe. A few, like Bishop Greer, could arge the nation to think calmly; more typical was the ory of the Rev. John Henry Jowett that "it is a colossal $s$ in against God and it is premeditated murder." The New York Sun felt that the loss of the 
Insitania, "was no different from the other sinkings except in size, but realized that a lot more excitement had been created." 1

But the reaction of the Northeast was not the reaction of the nation. Secretary of Agricultare, David F. Houston, happened to be in California when the disaster came. He was to met a delegation of Los Angeles business men that morning; the secretary was full of the news, but the business men merely "talked for a few minutes about the tragedy without excitement" and did not mention the subject again throagh the reat of a long morning. "Nor did any reporter of any local newspaper seek to interview me on the matter," though Mr. Houston was one of the most influential members of the Cabinet. "No citizen brought it ap auring the remainder of my stay in the west wich lasted sereral weeks." The overwhelming consensus appeared to be that the President should instant ly compel Germany to disavow, to make reparation and to aband on her sabmarine war, but at the same time making sare not to get the united States into trouble. "The American people," as the Savannah News observed, "don't want their government to be placed in the position of retreating from any position it has taken." ${ }^{3}$

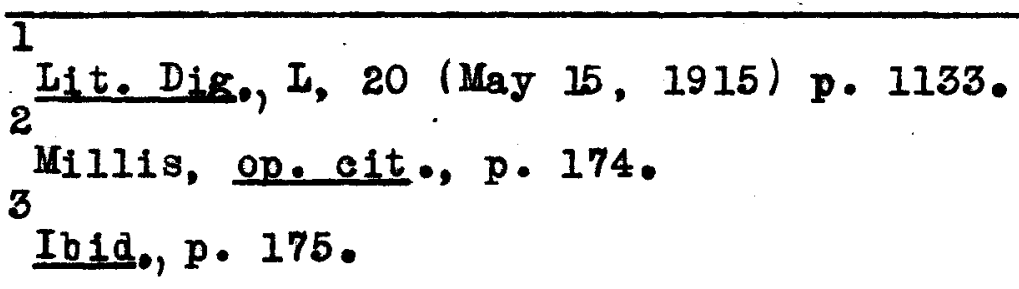


Wils on's attempt to preserve calm was criticized by some. Three days after the sinking of the Lusitania, President Wilson addressing 15,000 recently turalized citizens in Philadelphia, stated: "There is such a thing as a man being too proud to fight. There is such a thing as a mation being so right that it does not need to convince others by force that it is right. ${ }^{1}$ The New York Times expressed the solemn opinion that "this atterance of the President does not respond to the feeling of the people." The White House was flooded instantly with telegrams of condemnation; and before the swift storm of elegant disapproval the President was weak enough to announce that the speech had been made wi thout reference to the Lusitania. The loyal World hastened to express its relief at this disavowal. "We have a pride that will make us fight," it said, "Let there be no illusion on this score in Berlin or elsevere. ${ }^{2}$ Henry Cabot Lodge, promenent member of the Senate Foreign Relations Committee and political opponent of the President, felt that the statement "shocked him the same as many others and I never again recovered confidence in $\mathrm{Mr}_{\mathrm{r}}$. Wilson's ability to deal with the most perilous situation which had ever confronted the United States, in relations with the other nations of the earth."

The note of President Wilson following the sinking of the Insitania stated that he would hold the Germans to strict

1 Baker, op, cit., Vol. 5, p. 334. 2 Millis, op. cit., p. 178 .

Lodge, Henry Cabot: The Senate and the League of Nationg, p. 32. 
"accountability" and his firmness, untouched by hysteria, seemed to meet public favor. The second note was more severe and caused Secretary of State Bryan's resignation.

Pablic reaction to Bryan's resignation was divided. The Mobile Register stated: "If Germany is misled into actions still further violative of our rights, the resultant hostility will be largely attributable to Mr. Bryan, whose sole idea is peace", and the Philadelphia hecord sarcastically added, "The biggest popular vote he will ever receive will be in endorsing his resignation." But in the West and Southwest Bryan was given the benefit of the doubt. The St. Louis Republic added, "American people will not fail to give Mr. Bryan fall credit for his sincerity, his patrotism, his good spirit, but in the issue now joined the country is with the president." The Socialist New York Call cona emned the capitalists with a sweeping statement. "The DuPonts and Schwabs have at last pried from President Wilson's cabinet the last piece of timber that resolutely barred the door against $\operatorname{var} \cdot{ }^{1}$

It was at this time that the srench and their position 2 in world affairs were placed before the American pablic. The Outlook for May 12, 1915, carried an article entitled, "Plain 1 2 Ilt. Dig., I, 25 (June 19, 1915) pp. 1449-1450。 The Iiterary Digest carries no report on American action towards France in the same nner or style in which Great Britain is criticized. Reports are of a general nature dealing mostly with her war effort. 
words Irom $A_{m} e r i c a$ to Sister Nations in Earope," by "Civis Americanus." To rrance the writer said:

"Wo shall never forget jour friendship and help in the days when we won our freedom.... We cannot see that this war is in any way one of your choosing or of your making. No threat of yours, ho claim of jours, entered into the itches cauldron. "You have not talked much, but you have fought well. You have suffered enormously, but you have not lost jour nerve. -... Your silent General, your silent soldiers, your sober self-sacrificing people have de a splendid record." 1

France received further praise from Wayne Maoveigh in the North American Revier for July, 1915. NacVeigh stated:

"I know nothing more sablime in all history than the passion for liberty which animates today the children of France in their combat for their country and for the world against the crushing forces of Attila's Huns."

France was praised frequently for not carrying on the campaign of propaganda that Britain and Germany had andertaken; she was praised for sharing American ideals of democracy; she was praised because her action had disproved nitions carrent in America of her decadence, corruption, and instability. The Philedelphie North Amerioan on July 7, 1915 stated that they were surprised to find her so "quiet" and "stubborn."

"... the stirring thing is that france the frivolous, White, Elizabeth Brett: American Opinion of France, p. 273.
Ioc. cit. 
France the debonair, France the carefree and la ughterloving, has met the supreme ordeal of her existence in a manner to teach the whole world lessons of steadiness, of sobriety, of dogged courage, of concentrated efficiency, and of ancomplaining sacrifice." ${ }^{1}$

$$
\begin{aligned}
& \text { Henry Watterson had a kind word for the French. } \\
& \text { "I have not loved Paris as a Parisian, } \\
& \text { but as an American.... I used to love to go } \\
& \text { there and to behold the majesty of France. I } \\
& \text { have al ways known what al i the world now knows, } \\
& \text { that beneath the gayety of the rrench there } \\
& \text { burns a patriotic and consuming fire, a high } \\
& \text { sense of pablic honor; a fine spirit of free- } \\
& \text { dom.... Alone they did it-- the l'renoh people } \\
& \text {-- the hard-working, frugal, loyal commonalty } \\
& \text { of France-. wi thout asking the loan of a sou } \\
& \text { from the world outside." } 2
\end{aligned}
$$

Proof that the American press could still see both sides of a problem when so desired, occurred in Jane, 1915, with the announcement that Italy had entered the war on the side of the Allies. "Cold-blooded caloulation," remarked the Philodelphis Inquirer and the Washington Post saw "territorial covetous" as the reason. The Augasta Chronicle called the action "treacherg" and the New York World remarked that "Morally she stands ith Germany. Both tore up treaties of international significance." The Milwankee Free-Presg called the entry one "of the blaciest chapters of the war" and the New York Poat stated, "That it must be assumed that the Bllies outbid Germany."

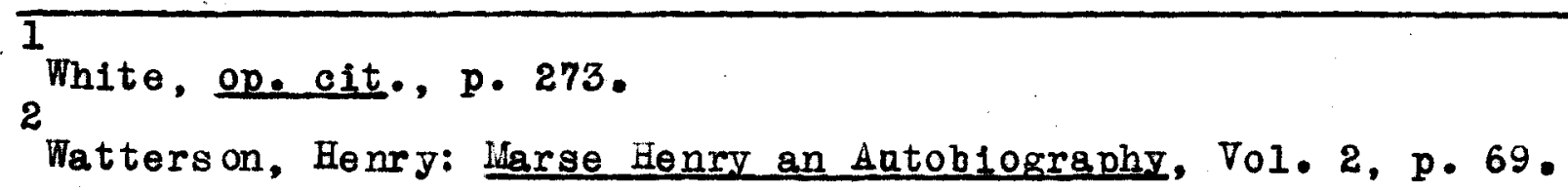


Few papers defended the action of the Italian government, despite her linkage to the Allied cause.

Col. Edward M. House, personal advisor to President Wilson, writing to Sir Edward Grey, British Foreign Minister, June 17, 1915, sammarized american pablic opinion:

".... the vast majority of our pe ople desire the President to be very firm in his attitade towarda Germany and yet avoid war. They have told me that in their opinion the country was willing to accept the consequences. ${ }^{2}$

A like opinion was expressed by several newspapers the same month, following the announcement that additional American lives had been lost wi th the sinking of the British liner, Arab1e. In the East the New York World announced that "every passenger ship, regardless of flag flying, presumably carries American citizens," while the Tribune believed that it was "time to act; wi thout delay give the German ambassador his passport." The West also backed the East with the Phoenix Repablican, the Cherenne Ieader and the Solt Iake Tribane calling for a "ruptare of diplomatic relations." The Literary Digest could find but one paper, the German-fmerican Cinoinnati Volksblatt placing the blame anywhere but on the Imperial government. "Difficulties," the Volksblatt stated, "with Germany could be easily averted if I Iit. Dig., L, 26 (June 26, 1915) p. $1543 ._{2}$
Sejmour, Vharles: The Intimate Papers of Colonel House, p. 12. 
Amerioans would place themselves ander the protection of their own flag and not of a foreign country."

Realizing the situation the nation was in, President Wils on fought for peace but at the same time he was determined to be prepared in case his plans failed. His previous call for preparedness without conscription (December 8, 1914) coupled with his St. Louls speech when he asserted that the American Navy "ought in my opinion, to be incomparably the greatest navy in the world," brought praise from the editors for what might have been two widely separate reasons. The Wrshington Post, which had been maintaining a middle-of-the-road attitude, felt that "we have the biggest job-- we need the biggest navy." The Milwankee Sentinel, the only American paper labeled by Wellington House as being pro-German felt the same way. "We must have enough power," the editor stated, "to defend the freedom of the seas." Apathy in Congress and dissension in his own party forced President Wilson, as the Cleveland Plain Dealer remarked, to carry the case for preparedness before "the real court of authority-- the men and women of the United States." Sectional feelings also flared up in sapport of the President's call for preparedness and the

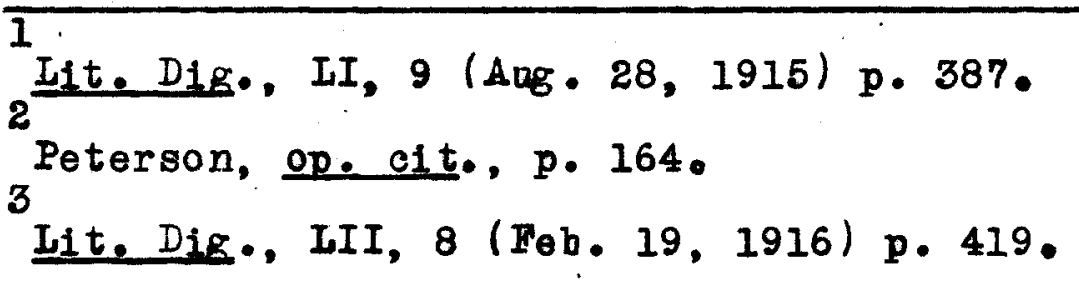


Winston-Salem Journal belleved that the "people of the midwest, not much wo rked up over preparedness will be awakened by the President," The Now York World called for the facts, stating that the "president is entitled to a hearing.... and had handled the foreign affairs of the country during the most trying period since the civil war." The Presg editor, seeking to look into the heart of the call stated, "He still hates the sword.... his heart is not in it. $n$

At the close of February, 1916, the Iiterary Digest editore placed another poll before the editors of the American press, this time asking; 1. What should be the size of the Army and the Nary? 2. Is militarism a peril to America? The answers proved to be almost an even split on the latter question with the biggest complaint being that the President would control the local militia over the voice of the governor if taken into federal service which would make for too much patronage. Averaging ap the figures submitted from 500 editors the Digest found them asking for a larger regular army of 285,078 with a reserve of $1,215,359$. Forty per cent wanted a navy second only to Britain with the remainder asking for the largest in the world. Along the Atlantic seaboard only 11 editors feared the rise of militarism with 85 seeing no harm in an increase on the services.

I IIt. Dig., III, $6($ Feb. 5, 1916) p. 269 .
2 Ibid., III, $10($ March 4, 1916) p. 547 .


Further West the editors called for a smaller army but a still larger navy and the fear of militarism was still strong.

The raid on Colambas, New Mexico, March 9, 1916 by bandits ander the leadership of Pancho Villa gave people calling for preparedness an additional argument. The new Secretary of War, Newt on D. Baker, who had taken over March 9, 1916, following the resignation of Iindle $y$. Garrison due to President Wilson's failure to back his proposed plan for conscription, was already on reoord for preparedness if possible without conscription. The Cleveland Plain Dealer, alreadj on record as backing Seoretary Baker and a preperedness plan, called it an "example of what unpreparedness means." The Kansas Citz Star pondered the idea of what might have happened and "suppose it had been a first class power, instead of a bandit?" Col. Edwin F. Glenn, chief of staff of the Eastern Division of the Army, and a man fully entrusted with national secarity stated, "The cold fact is that the American army today is the most pathetic thing any nation ever knew or contemplated, and other nations know it very well, I can assure you." Machine guns had failed and transportation was far from successful.

A report by two British journalists on the American press was published in September, one defending and one condeming $\bar{I}$ Lit. Dig., III, 11 (March 11, 1916) p. 617. Ibid., III, 14 (April 1, 1916) p. 883. 
American opinion towards the Allies. Both were probably biased. Arraon Watson, following a cross-country trip stated:

"Going west the less interest there seems to be in the events, which are making a charnel house of Europe.

"America has no journalist who makes an expert study of the war.... and there is no demand that the newspapers shall supply complete and anbiased news."

Mr. H. S. Perris, also a journalist, after a trip to Chicago reported:

"In believe, on the eontrary, that no press in the world has, on the whole been more fully informed of the underlying causes and issues of the war, and the general oourse of events, than the leading journals of the United States." 1

Both reports were probably true to a certain extent. The West was little interested in the conduct of European affairs, but it was stretohing a point to say that no American joornalist had me an "expert study of the war." Recognizing that American news came largely through British hands, my American journals were still printing both sides of the story as far as possible. At 8:30, Saturday evening, Hebruary 24, 1917, there arrived in the state Department a sensational cable from Mr. Page, our Ambassad or to England. The British Foreign Minister, Mr. Balfour, the Ambassador reported, had just handed him the text of a cipher telegram from Zimmerman, German Foreign Minister, to the Imperial Government's Ambassad or to Hexico, which had been trans1

Ib1d., II, 11 (Sept. 11, 1916) pp. 528-529. 
mitted on January 19, through the American Embassy in Berlin to the German Embassy in Washington.

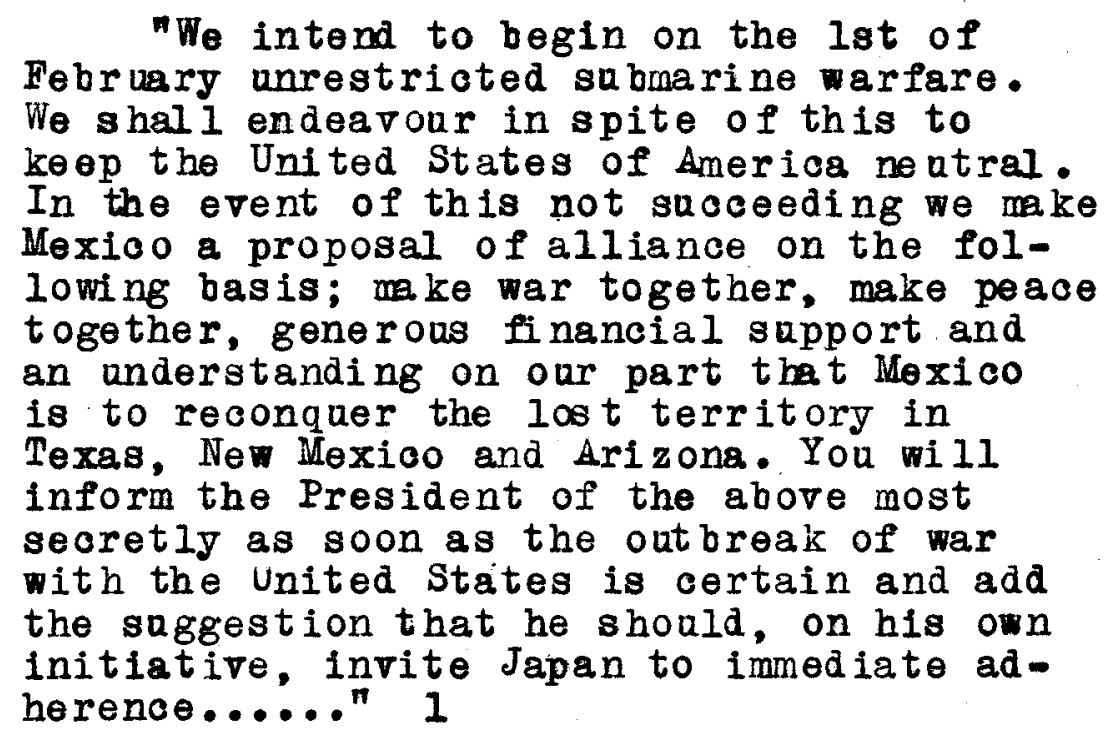

The reaction of the Amerioan press was violent while

the German-American press could "see" Praud and British trickery written throughout the message. The Springfield Republican, already anti-German, called it the roice that could "solidify America," and the Oshkogh Northwesterner remarked, "Patriotism has been fanned into a flame of fervent loyalty." The St. Louis Amerika declared "no hestation in declaring it a forgery," while the New York Fatherland labeled it, "brazen forgery; impudent hoax." The Milweukee Free-Press, called the only pro-German American newspaper printed in English, remarked it was a note "which even a schoolboy's sense should suspect of spuriousness." But there can be no doubt as to its genuineness for zimmerman when confronted for reasons for his action stated that "Germany in

$$
\text { Ibid., LIV, } 10(\operatorname{March} 10,1917) \text { p. } 607 .
$$$$
\text { Ibid, IIV, } 11(\text { March 17, 1917) p. } 687 \text {. }
$$ 
order to win the war neoded Allies." ${ }^{l}$

The press as a whole supported the action of arming our merchant vessels, following the pablication of the Zimmerman note, and the Boston Journal believed that the "outcome commonly expeoted is war." The Detroit Journal felt that the President "has taken the right course and dangerous," while the Milwankee Journal believed the "action will be endorsed by every citizen." The Nashville Tennessean, a little more conservative, felt that "90 per cent of the people will applaud him," and the Chicago Herald could see "no turning back." The New York Sun attempted to speak for the state Department and remerked, "Government offioials expect war anless Germany does an about face."

Following a meeting of the Cabinet, March 20, the Ifterary Digest reported that we changed from "armed neutrality" to "a state of war." ${ }^{3}$ Commenting on the coming session of Congress, most of the American press seemed to feel the same way. "It will be the duty of Congress to recognize the fact of war and authorize the President....", stated the New York Timso. The Boston Transcript felt that "Germany as at war with us and we should be at war with Germany." The New York l'ribune wanted to know "what we were going to do about it?" and the Cleveland Press believed "war is inevitable." 4

$\overline{1}$

Halsey, Franc is Whiting, The Literary Digest History of the World War, Vol. 4, p. 15; see also Enoz. Brit. Vol. 23, p. 950. Iit. Dig., IIV, 12 (Maroh 24, 1917) p. 801. Ibid., IIV, 13 (Maroh 31, 1917) p. 881. Loc. cit. 
The action of Congress, April 6, 1917, in deolaring war against Germany found the American press anited behind the call to arms. 'I'he Chicago Herald stated; "If this, indeed, be not the volce of the nation, we are not fit to be a tion," and the Courier-Journal remarked that it was the "most significant and momentous deliverance on the part of the American pe ople since the Declaration of Independence." The Boston Transcript heard the voice of the people with the remark, "the president has he eded the mandate of the people." The pro-German press and the German-American press also fell into line. The Milwanke Free-Press patriotically calling that "where the flag leads all America will follow" and the New York Stakts-Zeitung could see one goal and "but one duty-- America."

1 Iit. Dig., IIV, 15 (Apri I 14, 1917) p. 1002. 
IV. THE REACTION OF CHURCH AND PACIFIST GROUPS.

Where God hath a temple, the devil will have a chapel.

Robert Burton

Anatomy of Melancholy 
general found the American clergy condemning the warring nations and asking for peace. The Bishop of the Protestant Episcopal diocese of New York, Dr. David H. Greer, was one of the first to call for peace, publishing a prayer for use in the churches of his diocese during the war stating, "We are brethren.... open the ejes of the people.... hatred and violence is weakness.... bring to a speedy end.... war shall be no more." ${ }^{1}$ The last proclamation of Pope Pius $X$ was is sued the day of his death (August 19, 1914) calling to all Roman Catholics to pray for the "speedily removal of the evil causes of war, giving to then who rule to think the thoughts of peace." The Rev. Fiederick Iynch writing in the Christian Work and Evangelist (nondenominati onal), Aagust 29, 1914, stated that "Christianity has been thrown to the dogs, and the nations have gone mad." The Lutheran (Philadelphia) organ of the Evangelical Lutheran Charch of North America agreed; "All nations have drank deep at the well of irreligion and mannomism.... all nations are equalig to blame."

Rer. Holden E. Sampson of the Corpus Christi

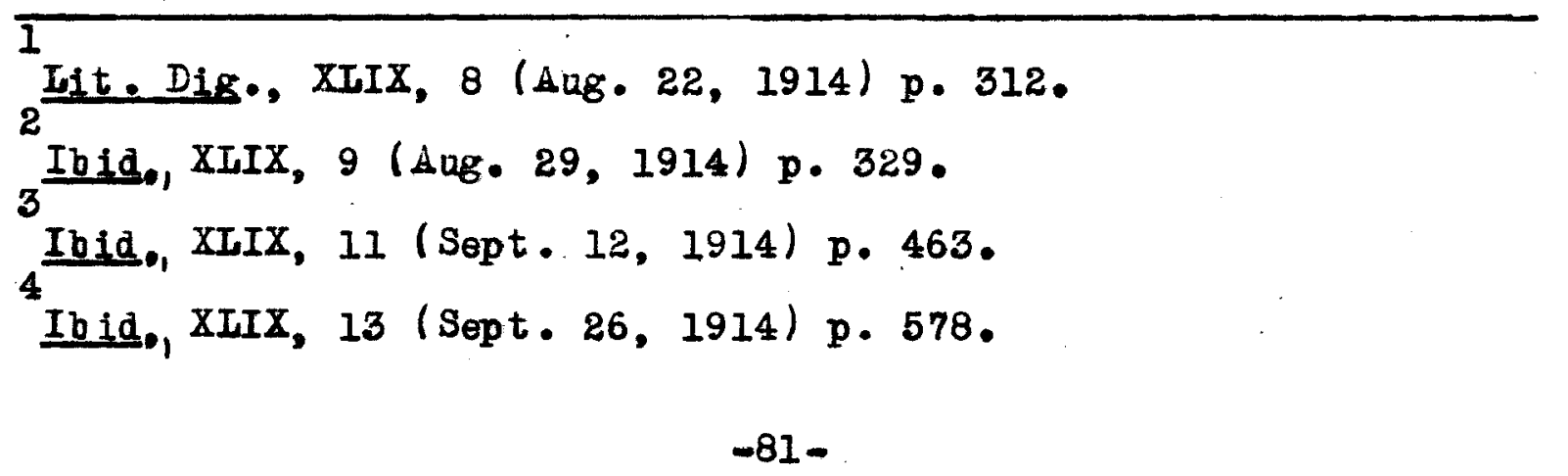


Charoh of New York City, was one of the few roices of dissent. Writing in the New York World be stated, "war is not all bad. ... there are some good things.... we are too self-centered and shrink from death."

The nation's response to the President's eall for prayers for peace "could not have been more general or more fervent" in the words of the New York Times. The Living Church (Milwaukee) added that the netion should "pray for international peace." ${ }^{3}$ Whatever the course and final settlement of the war, stated the Brooklyn Eagle, the position of the Catholic Charch has been demonstrated in the Pope's recent enojolical. "No oritic in the world can misunderstand it."

By Christmas of 1914 members of the ministerial groups were actively engaged in the American Ieague to Iimit Armaments to combat the forces calling for increased defense. Those engaged included Bishop David H. Greer, Percy Stickney Grant of the Church of the Ascensi on, New York City, and William Pierson Merrill, minister of the Brick Presbyterian I 2 Ib1d, $p \cdot 578$. Ib1d, XIIX, 16 (Oct. 17, 1914) p. 742 . 4 Ioc. oft. Ibid, XIIX, 23 (Dec. 5, 1914) p. 1126. 
Church of New York City. Bishop Greer also headed the Church Peace Union and maintained that "peace will never be obtained by the ase of force. The teachings of Christ, the manner of his life and of his death, were proof that he would be opposed to $\operatorname{war.}^{1}$

The efforts of the paifist organizations to enlist church sapport tended to inerease the antagonism of some of the clergy towards them. Dr. Charles A. Eaton wanted to know "who are these people imposing on simple half-baked women, making their husbands hang their heads in shame?" Maloom J. Maote od couldn't believe that if Jusus were living in the present he would be a pacifist; "I believe there are times when to be a pacifist is to be perilously near being a traitor." Dr. Walter Rausohenbusch of the Rochester Theologioal Seminary, writing in the Congregationalist (Boston), first confessed to German descent and then stated "there is not a nation at war which has not some justification and some spiritual values at stake." He defended liermany bat not to the extreme, stating, "Nations rarely fight for moral issues alone." The governor of conneoticat, actire in the work of the Baptist

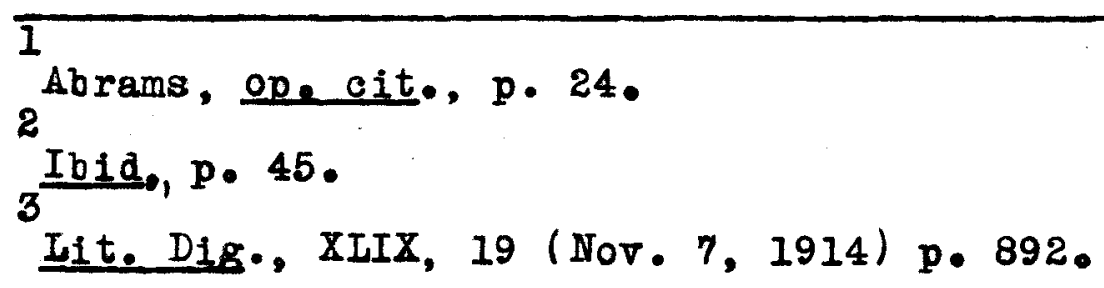


Churoh, requested the churches "to gather a census of the state's war material in men." ${ }^{1}$

The Literary Digest could see no division along denomo inational lines in the ministerial stand against an increase in armaments and stated "there is no significance in the fact that it is the Protestant Christian Work (New York) which believes Mr. Bryan's peace treaties worth a big army in every state." The Catholic response was the same. The Catholic Monitor (Newark) stated. "It is to the credit of our people that they are sincereIy desirous of peace." All denominations called for "moral rearmament. ${ }^{2}$ In his struggle to combat militarism, Dr. Frederick Iynch wrote in The Christian Work. "Our noise in the world is not measured by our guns. Our safety does not depend upon our navy but upon our reputation."

But what attitude would churchmen take when war's problems came closer to our shores? A survey of the opinions of church leaders of the nation was pablished by the New York Times, May 10, 1915, three days after the Lasitania was torpedoed. Collecting pulpit expressions the Times reported that the general reaction of the clergy was: "A crime against civilization; an act not to be condoned; not piracy but organized murder; abhorrent even to

Ibrams, op, cit., p. 46.
2 Iit. Dig., XIIX, 26 (Dec. 26, 1914) p. 1281.
3 Ibid., I, 11 (March 15, 1915) p. 551.


the standards of bloody war." The Rev. John Henry Jowett stated, "It is a colossal sin against God and it is premeditated murder," and Rev. Henry Sloane Coffin saw the action as a conflict between "barbarism and civilization." The Times editorialized, "Possibly some of the clergy have counseled turning the other cheek, but if so we have not seen their words in print." ${ }^{2}$ But some words were in print. i'he Rev. John Hagnes Holmes of the Church of the Messiah, New York, stated,".... show that America belives in peace", while Ker. J. F. Keller of the Erangelical Iatheran Charch, Cleveland, remaried, "These passengers were warned before they sailed.. -. war is war." The influence of national origins is seen in some cases. In Chicago, an appeal was published on Saturday, May 8, in several linicago newspaper articles signed by Luthe ran clergymen, calling upon the German pastors in the interest of "truth and justice" to call the attention of their congregations to the fact that "the German government had been forced by England to the horrible steps, and, according to international law, is not responsible for the loss of American life." One Iutheran pastor pointed out that the passengers had committed suicide.

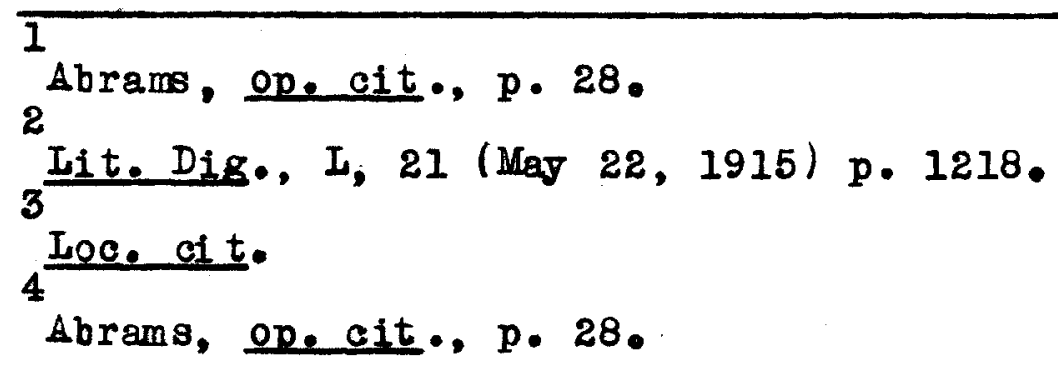


The lass of American lives due to submarines placed the word "preparedness" foremost in the minds of many Americans. The Security League had already issued a call for increased armaments and the jounger business men and millionaires, baok now from their bloodless trenches at Plattsburg, were organizing the Military Training Camp Association to put more powerful pressures than General wood himself could exert upon the Congress about to convene. Colleges were adopting Reserve Officers Training Corps.

Both the Congregational and Disciples of Christ Charches struok back againgt this call with official statements. 'I'he National Council of the Congregational Church, meeting at New Haven, Conn., passed a resolution pointing out ".... the futility of gigantic armaments as the guaranty of international security and justice. ${ }^{2}$ The christian Century (Chicago) the official organ of the Disciples of Christ, remarked that it was "time for religion to enter politics to strive against militarism."

With the arrival of the new year (1916) The Literary Digest felt that "while much of the pacifist sentiment has $\overline{1}$ Millis, on, cit., p. 235. 2 Iit. Dig., LI, 21 (Mov. 20, 1915) p. 1009. Ibid, 24 (Dec. 11, 1915) p. 1256. 
emanated from clergymen, it appears to be an error to look upon this body of men as a whole as holding to the doctrine of non-resistance and opposing the wide-spread sentiment in favor of preparedness," and published a poll of Presbyterian ministers taken by the Continent (Chicago). The Digest editors also felt that a complete nation-wide view was impossible due to the scarcity of Presbyterian ministers in the New England and Southern states.

The poll:

1. Are you in favor of complete disarmament by the United States?

Yes, 95; 10, 305; No vote, 29 .

2. Are you in favor of an Army

and Nary sufficient in numbers and effiency to withstand ordinary attack while new forces are being organized? Yes, 375; No, 60; No vote, 37.

3. Are you afraid of the dangers of militarism?

Yes, 115; No, 278; No vote, 37.

4. Assuming that all war is wrong

should we ignore the possibility of attack

by some nation which does not accept thet belief?

Yes, 76; No, 278; No vote, 47 .

5. A variety of reasons were given

as to the best method of defense.

The editor of the Seattle Post-Intelligencer, probably

finding the results of the poll agreeing with his own ideas, stated that the "Presbyterians are a good cross-section of the country.. -. the doctrine of national preparedness is decidely more popular in this country than had been supposed."

\section{$\overline{1}$}

Ibid., III, $2(\operatorname{Jan} .8 ., 1916)$ p. 156. 
About the same time a poll of ministers of twenty-lenominations in Brooklyn; conducted by the Daily Eagle, found a large majority faroring preparedness. A total of 151 farored an increase in armaments with six qualifying their approval and but 14 opposed. The Eggle, probably remembering that the ordination into the ministry does not insure one against cultural influences, editorialized, "It seems that ministers in a given locality are perhaps affected by the same influences as other citizens and are just as good patriots as lagmen. $n^{1}$ Charles A. Eaton, through the pages of The Independent (March, 1916) gave assurances that "this war is the greatest blessing that has ever fallen on mankina since the lerman Reformation."

Sunday, October 4, 1915, the day set aside by President Wilson for prayers for peace, was widely observed in the charches. The New york Times featured the occasion on the front page: WHOLE NATION PRAYS FOR PEACE. MOst of the clergy caught the spirit of the day, making strong appeals. Bishop William Lawrence of Massachusetts believed that "people were becoming convinced that war was wickedness, useless, and stupid." Malcolm James MacIe od, of the Collegiate Charch of Saint Nicholas, New York City, asked his hearers to "think of the dead boys today, the maimed and the crippled. I don't care whether they are Germans, English or Russ-

I Ibid, III, 15 (April 8, 1916) p. $972 ._{2}$
Abrais, op. cit., p. 33.


ians. They are all their mother's sons and the sacredness of human life is degraded. Worst of all is the moral degradation and the legacy of hate. $n^{1}$

The British government, realizing the value of having the clergy speaking for the Allied cause, published a book in 1915 entitled Sixty Amerioan Opinions on the War and the names of certain clergymen found their way into the pages. One of them was Frank Isley Paradise, rector of Grace Churoh, West Medford, Mass., who in January, 1915, had said from his pulpit:

"At length, I do believe we shall catch the spirit of battle, and fling back the challenge of German nationalism. For we too have a consoious national desting. The God of Israel has annointed us to champion the cause of the poor, the weak, and the down-trodden. We too shall struggle for world power. It will be the healing power of Christian civilization." 2

But statements/such as these were the exception, rather than the rale.

President Wilson's call for peace following his re-eleotion (Deoember 18, 1916) found support in the pages of The American Hebrew. "We count it more than fortanate that we have at the head of the nation a man who towers head and shoulders not only above our statesmen, but also above the trained statesmen of Europe.... a burning passion for peace and righteousness." ${ }^{3}$

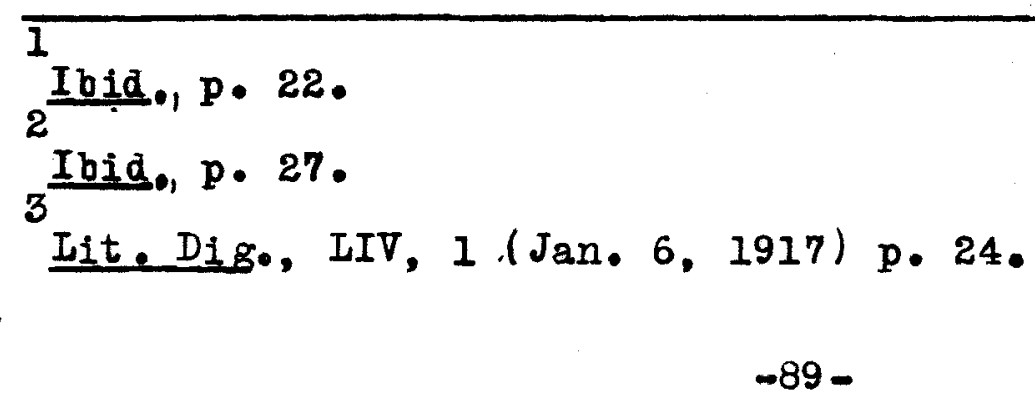


Following the German note of January 31, 1917, notifying the world of unrestricted submarine warfare and making our entry into the war almost inevitable, The Ifring Church (Milwaukee) and. The Churchman (New York) wel comed the suggestion of the Episcopalian Bishop "to place flags in all our churches to teach the relationship of the church to patriotism and its Christian expression." 1

Follow ing the ruptare of diplomatic relations (March 4) and despite the isolated actions of certain ministers in continuing the ir fight for peace, the New York Federation of Churches decided to "mobilize its Christian strength behind President Wilson, pledging to him all the service of which we are severally and collectively capable and to make a stand for the immediate establishment of universal service." Sunday, March 11, 1917 was designated as "War Sunday" in the New York Churches. One hundred and fifty-eight churches favored the call with 52 voting against it. Results: Presbyterian, 27 for, 22 against; Baptist, 16 for, 1 against; Congregationalist, 10 for, 0 against; Episcopal, 27 for, 3 against; Methodist, 23 for, 4 against; Reformed, 19 for, 3 against. Voting in a group the Evangelical Association, the Society of riends, the German Evangelical Synod, the Lutheran Danish, the Keformed Episcopal and universalist rejected the motion 11 to 2. Some ministers proclaimed the "Holy War" from many palpits. In Brooklyn, Dr. Newell עwight Hillis brought his congregation to its feet in un-ecclesiastical cheers with his I Ibid, LIV, 8 (Feb. 24, 1917) p. 473. 
sermon: "Why We Should Go to War with Germany." A resolution in favor of conscription and pledging support for war was adopted by 158 congregations in the city. "Our churches," said the Reverend Charles A. Eaton in the Madison Avenue Baptist Church, "have been preaching what amounts to a moral asphyxiation. Pacifists afflict the country.... They make me want to swear, pray, la ugh and weep." It was a performance echoed in countless other cities.

The announcement that Congress woald meet in special session, Monday, April 2, 1917, focused public attention on what was expected to be the President's war message. A survey of the churahes of New York City found militancy again rising from the pulpit. Rev. Newell Dwight Hillis in Henry Ward Beecher's Church stated, "It is the solemn duty to send to Earope.... money, soldiers and gans in the Ratior France sent to America." The congregation immediately drew ap a resolution, asking Congress to declare war. Rabbi Samuel Schulman of Temple Beth-el, toned down his call for war, but assed for a united front,".... no impression to go abroad that the country is divided." A Catholic spukesman, Father Jahn.Hughes of the Paulist Hathers, echoed the cry. "We priests are ready and I say 'God bless us. I"

Ibid, IIV, 12 (Maroh 24, 1917) p. 820.
2 Ibid, 15 (April 14, 1917) p. 1064.
Ioc. c1t.


There was at least one New York minister of the Gospel who refused to be swept away by the tides of war emotion. At the Church of the Messiah at Park Arenue an 34th Street, the Reverend $M_{r}$. John Haynes Holmes, a worker for peace since the outbreak of the European struggle, refused to alter his opinion and his morning sermon was a passionate declaration of faith:

"If war is right, then Christianity is wrong, false, a lie.... No order of a President or a Governor will persuade me or force me to this business of killing.... Other clergymen may pray to God for victory for our arms. I will not. In this church, if nowhere else, the liermans will still be incladed in the family of God's children." 1

Reverend $\mathrm{Mr}$. Holmes" sermon gave his trastees a bad afternoon. "Dr. Holmes is an ideal ist," one of them explained to the reporters, but this was not "the time to put his idealism into practice. We are not going to lie down and let vermany or anybody else wipe up the floor with as.... The Church of the Messiah is going to fight first.... to protect American right and American lives, and after we have protected them we will go on with our ideals."

Some of the most extended efforts in the field of propaganda were made in the religious fields, but as to its effect we ma only surmise on the fact that the majority of the churches

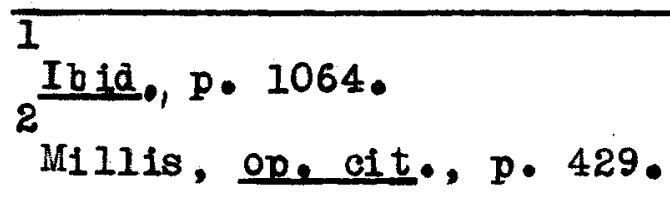


blessed our entry into the war. Wel lington House, the headquarters for British propaganda, sent appeals to all religious sects but. specialized on Episcopalians, because of their British background and the Catholics, due to the large number of Irish in the church. They popularized and almost canonized Cardin l Mercier. A vast amount of literature sent to American priests and preachers and many news stories seem to have been composed especially for 2

their benefit. The flaming vocabulary of religion still has the power to move the hearts of many men, and it is a poor propagandist who neglects the spiritual and ecclesiastical interpretation of the war by the spakesman of every sect. "The churches of practically every description can be relied upon to bless a popular war, and to see in it an opportunity for the triumph of whatever Godly design the y choose to further."

The following week after our official entry into the war, the Literary Digest could not find one official church spokesman crying out for peace. The Methodist, Congregationalist, Presbyterian, Roman Catholic and Episcopal echoed the call of the people.

1

Desire Joseph Mercier: Belgium Cardinal, Archbishop of Malines and primate of Belgium. 1851-1926. Noted for his fearless and determined attitude against the invading liemans. Received by King and Queen of England, 12 Sept., 1914, in celebration. On death of Pope Pius $\mathbf{Z}$, French and English Cardinals proposed him for Pope. German and Lustrian against move oalling it, "ohurch in politics."

2

Peters on, ope cit., p. 28 . 3

Lasswe 11, ope cit., p. 71. 4

Ibid, p. 73 . 
Even the Society of f'riends (Quaker, Philadelphia) whose faith forbade them to bear arms informed the government that "organization and systematic giving is our duty."

Despite the war-like stand taken by a mority of the clergy, other churoh leaders, as mentioned above, were working daily for the cause of peace. It was a long hard struggle, for organizations, such as the National Security League, were publoshing a most convincing type of anti-pacifist propaganda.

"In the vocabulary of the league the terms 'German, pro-lerman, pacifist,' and 'anti-preparedness adrocate' became synonymous and indistinguishable. One who favored the Allied cause was a patriotic American: one who favored the German side -- nay, even one who sought to maintain a ne utral position-- was a 'hyphenated smerican, a dangerous alien, a spy, a traitor. In its cry for increased armaments it claimed to be 'the best peace society in the United States.'" 2

The popularity of peace societies in this country in 1914 led many observers intereated in that movement to believe that the "Golden Age of Man" was just ahead. Michael Clane, addressing the annual meeting of the New York Peace Society in May of that year, reflected the spirit of optimism. "Ambition," said he, "will never again drench a continent in blood. A higher of vilization than war's is appearing." At the outbreak of the European war, the American Peace Society, through its president

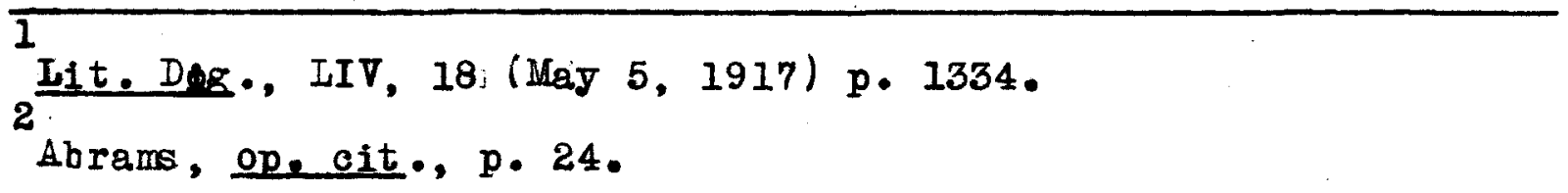


Senator Theodore E. Burton, and Arthur D. Call, the secretary, issued a statement to the people of the united States, declaring that causes of the conflict to be military preparedness in Europe, and asked our citizens to unite "in prajer and supplication today and tomorrow, and .... on each succeeding day until world peace is restored."

The first organized morement in America di rected towards the cessation of hostilities was placed before the public d uring the winter of 1915. Headed by the Englishwoman, Mrs. Pethwick Lawrence, and assisted by the brillant Hungarian, Rosika Schwimmer, a crusade against "the common enemy of mankind" was preached throughout the nation. This movement inspired Jane Addams to found the Woman's Peace Party, dedicated to urging the immediate discussion of reasonable peace terms. The following spring Jane Addams led a large delegation to The Hague hoping to found a women's world wide peace conference that would call the goremments to their senses and end the conflict. But as the golden stream of war orders spread through our economy, such efforts by visi onary females were regarded with an only more soornful amusement. The more sophisticated peace movement was careful to aroid entanglement in anything so "impractical," clinging to the more popular objective of

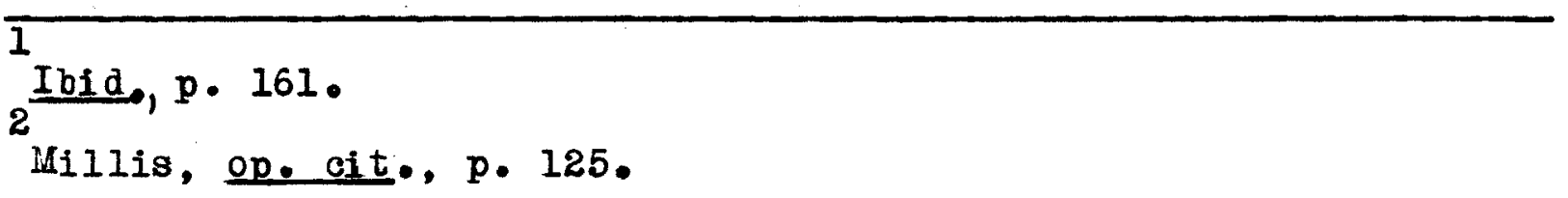


organizing peace only after the current war had ended in victory for the Allies. It was on June 17, 1916, that the League to Enforce Peace, the flower of this altruistic agitation, was formally launched at Philadelphia. Ex-President Taft was at its head; Dr. A. Lawrence Lowell was chairman of its executive committee; and many other eminent and high-minded men were enlisted in its ranks. A powerful propaganda engine had been created to add the military strength of the United States to the guarantee of a "permanent:" peace system, once the Allies should have safely destroyed "Prussian Militarism."

On December 4, 1915, the steamship Oscar II, ohartered by Henry Ford, sailed for Europe with 83 peace missionaries aboard to "get the boys out of the trenches by Christmas." But too ny important people had withdrawn from the ressel and the entire attempt was a fiasco. Ford left the party at Oslo, Norway, although a few die-hards moved on to Germany and France only to find their efforts useless.

The fight to force peace through negotiations was dying a slow death in the struggle against those who favored peace after victory. Then on the night of February 3, 1917, just three days after the German note informing the world of unrestricted submarine warfare, the pacifists mae their last stand. William Jennings Bryan, speaking to a crowd of five thousand or more in

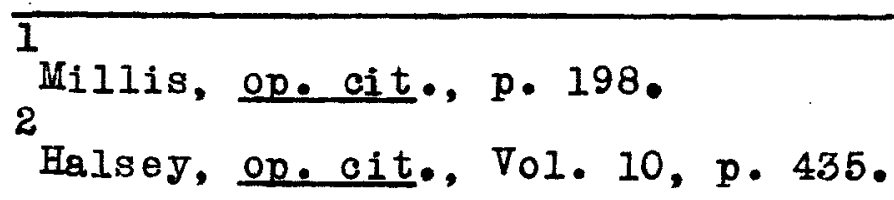


New York City, was cheered when he arowed that the United States wo uld not "get down and wallow in the mire of human blood." Out of this me eting/the Emergency Heace Federation, sponsored by several peace organizations, took form. In the next three months it raised over $\$ 76,000$ for its work. In Washington, an Emergency Peace Federation Committee/was formed, while in Chicago, long an active peace center under the inspiration of Jane Addams and Louis P. Lochner, the pacifists began to take steps calculated to prevent our involvement in war. On February 12, a large delegation of pacifists encamped at washington. Meetings were staged and conferences with Congressmen held. Lavid Lawrence wrote to the New York Evening Post: "Somehow, the pacifists got a better reception than their most enthusiastic followers have believed was possible in the national capital."

Early the next month Jane Addams visited President

Wilson and told of her reception:

"He still spoke to us as to fellow
pacifists to whom he was forced to confess
that war had become inevitale. He said
that as head of a great nation participa-
ting in the war, he would have a seat in
the peace conference, but that if he re-
mained the representative of a neutral
country he could at best be on call through
a crack in the door. It was as if his
heart's desire spoke through his words
and dictated his view of the situation." 2
Certain pacifist groups, notably the flying squadron of
led by Chancellor-Emeritus David Starr Jordan of Stanford
op. cit.. p. 44.


University, continued the ir energetic but futile efforts to stem 1 the tide of war.

As the country edged closer to the brink of war complaints began to pour in from the more radically-minded members of the peace societies, claiming that the organizations were "side-stepping and watchfuly waiting," and were "parties to a conspiracy of silence." As if to sabstantiate these claims, various branches of the Society told of blacksliding members. The President of the Derry Peace Society in New Hampshire complained because the leading members of the state organization "had joined the great preparedness army just now sweeping the country." On the eve of our declaration of war, the Society stated the rather obvious fact that the decision to enter or refrain from entering the war had "to be made by the United States government," since the American Peace Society could not "decide the question." On the last day of March, 1917, the Springfield Republican (Mass.) had already congratulated the organization on being such a "good loser."

Another group that must be taken into consideration was the Socialist Party, the arowed party of pacifism. Meeting in Convention at St. Louis, in 1917, the party declared the struggle a capitalist war and promised opposition to its prosecution, a step which led to the eventual arrest of many Socialist leaders, among them Eugene V. Debs, frequently the

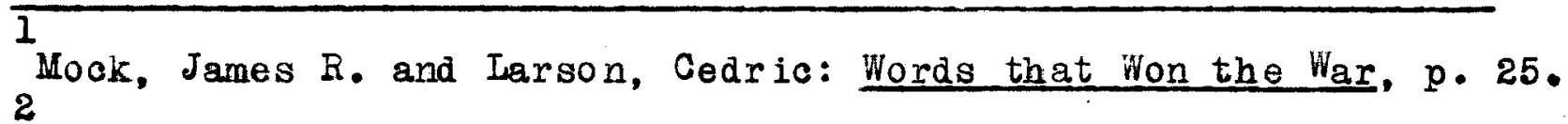
Abrams, op. cit., p. 161.
} 
Socialist party's candidate for president. The great wartime schism in the ranks of the Socialists did not ocour until the middle of April, 1917, but throughout March the press had carried stories reportine the conversion of individual Socialists who had previous ly opposed entrance into what they regarded as an Imperialist war. Those who left the fold did so on the belief that the war was a war against autocracy.

The basic reason for the trend of the American churches from peace, to preparedness, to war, is apparent. Uhristians and Jews have simply'used the Bible to aid in rationalizing any practice or idea which they were carrying out and believed to be justified. It is thus a commonplace that the Bible has been quoted to justify nearly every practice and belief know to man; war and peace, slavery and anti-slavery, child labor, polygamy and monogamy, celibacy, the burning of witches and the torture of heretics, capital punishment, women suffrage, communism, capitalism, the charging of interest, temperance and absolute prohibition, faith healing and etc. And finally the love of country exceeds the love of manind. Priests and ministers called each other names and accused one another of worshipping false gods. It became a "Holy War." Another vital relationship is that which exists between the religion of Christianity and the religion of Nationalism. The churches were consistent in the record of supporting all popular wars and proved, what had long been sus1 American Labor Year Book, 1917-1918; pp. 373-379. Abrams, op. cit., p. 252 . 
pedeted, that Christianity has been becoming increasingly nationalistio, while the god of Nationalism is more powerful in his ability to command obedience and devotion unto death than is Jehovah himself. Nationelism reached its highest development during the First World War. There were thousands of appropriate places of Christian worship, as in the First Baptist Church of New London, Conn., for example, the pastor, a chaplain during the war, preached in his uhiform with a machine gun and an American flag on the platform beside him.

The conception of war as inevitable and as salutary under certain conditions is held by many conservative theologians. They do not regard it as having a place in the ideal order but regard it as a necessary evil. A still more serious consequence of a literal interpretation of Jesus" teaching concerning nonresistance is its bearing on the state. Its primary purpose is to defend itself and its citizens from unjust attack. This is the function of the army and the police. Without such ase of force the state would disintegrate and there would be anarchy. The attempt is often made to draw a fundamental moral distinction between an army and a police force. But in theory there is no essential difference. Indeed, anyone who believes in the state and anderstands what this means must also believe that under 1

Abrams, op. cit., p. 245. 
certain cirsumstances war is morally justifiable.

The steady stream of atrocity stories, the suppressIng of all evidences of better feeling on the part of any section of the German people, the disheartening effects of the pronumciamento of the German intellectuals, the honest and sincere revulsion of feeling against a nation that action of whose leaders had planged mankind into these unspeakable horrors-all worked to make righteous anger seen a Uhristian duty. The fact remains that in the heat of the struggle the judgment of many a minister did not conspicuously rise above that of the average citizen. The menbers of the cloth and their followers were susceptible to war psychology and crowd-thinking in the same manner as were the other citizens. 'l'hey possessed no prophylactic against the mob mind.

In the first of the World Wars organized Christianity tended in general to endorse the cause of the Allies against the Central Powers, although favoring neutrality, and later supported the participation of the United States, in a war which they had come to regard as righteous.

$\overline{1}$

Knuds on, Albert B.: The Principles of Christian Ethias, p. 225. 2 Brown, William Adams: The Charch in America, p. 97. 3 Abrams, op. cit., p. 246.

Latourette, Kenneth Scott: A History of the Expansion of Christianitr. Vol. VII, Advance l'hrough the Storm, p. 148 . 
V. THE REACTION UF BUSINESS AND IABOR.

Business is a combination of war and sport.

And re Ma uro is 
The mast convenient classification of the principal causes of wars as we see them to have arisen in history is; religous, political and economic. 'l'he latter two, especially, are intertwined beyond the hope of disentanglement.

The story of American political involvement as a result of economic pressures is easily followed by a series of successive steps. First, a policy of atrict neutrality was followed. Ihen the permitting of private loans to belligerent nations followed. Third was the period of armed neutrality and then war itself. It must be remembered that Britisk trade restrictions were not devised for the purpose of arawing the United States into war. The primary object was to injure the enemies of Great Britain by every means legal and illegal. It sought, according to Winston Churchill, to treat, "the whole of termany as if it were a beleaguered fortress, and avowediy sought to starve the whole popalation--men, women, and children, old and young, wounded and sound, into submission." The British government at the outset of the war realized that American economic assistance would be needed to bring the straggle in Europe to a successful conclusion, but only gradually did they realize the extent of their dependence on the American economy.

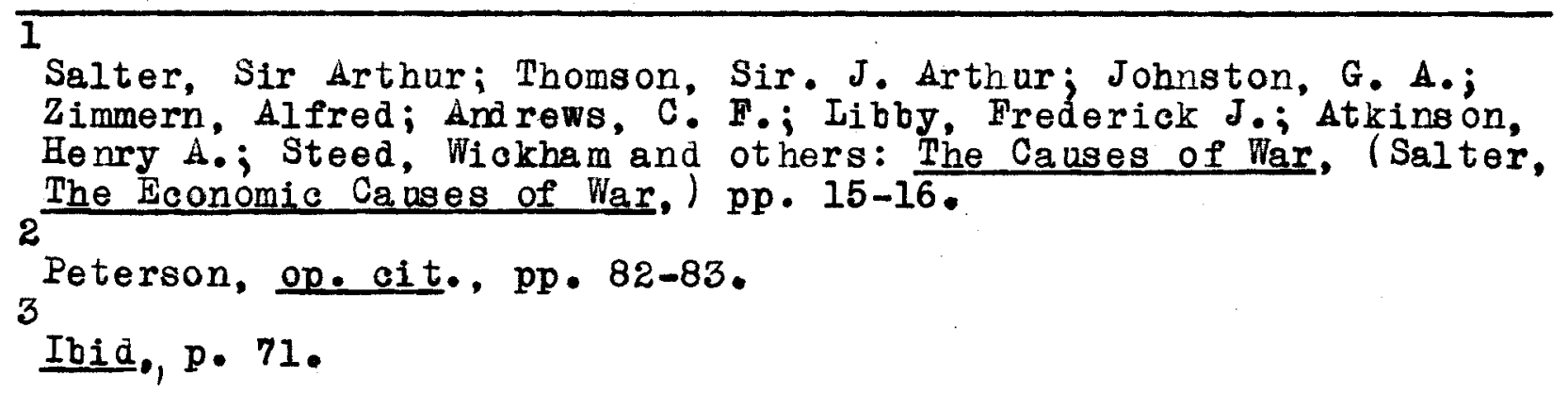


From almost the first, British naval power and policy made American foreign trade dependent upon the actions of the British government. It also ca used the bermans to retaliate and thus come in conflict with the american government. Later, large munitions contracts in this country meant high wages and higher profits for thousands of people in dmerican ind ustry. The next act was loans to Britain. These gave some Americans a vested interest in the Allied cause. All three combined to create good will between the United States and Great Britain and, indirectly, to create ill-will between the united States and Germany. Each step was propaganda in the most practical sense of the word. The American policy at the outbreak of the war was in strict accord with the rules of international law, which states, "Neutrals may legitimately carry on all sorts of trade, and belligerents may interrupt all." Thus Britain, controlling the surface of the seas, was able to halt American trade to the continent without destruction of American lives and shipping, and Germany, forced to: retaliate with her only weapon, the submarine, found hersolf alienating the American pablic. 'the aspects of the economic warfare as carried on by Great Britain, although fully within the bounds of international law, was described by many in the war-

$\overline{1}$ Peterson, op. cit., p. 71 . 2 Woolsey, Theodore $D_{0}:$ Introduction to the Study of International Lew, Chpt. 2, ذec. 184, par. 3, p. 309 . 
time phrase, "Great Britain rules the wares and waives the rules." Representative Towner of Iowa was one of the few who looked into the future and forsaw the danger. As early as Angust 28, 1914, he spoke against our basiness policy on the floor of Congress. To ship food and clothing to the Allies, he warned his courtrymen, was to aid them in their struggle with Germany and Austria. "At best we would be fortunate if we could avoid being drawn into the war;" but to encourage even commercial exports to one side, when the other was debarred from our markets, would be "to invite our own entanglement."

Towner took the position of Secretary of State Bryan who believed that if we are neutral $b$ all belligerents should ree ceive exactly the same treatment at our hands, [this wanld involve strict prohibition of all trade and relations wi th all nations as reselling of our material by another neutral mation might involve us] even though this would involve the government in a new interpretation of international and united States law, as we were at the time functioning ander previously agreed apon rules. The President took the stand that rales could not be changed for the advantage of one contestant.while the struggle was on, and set his face

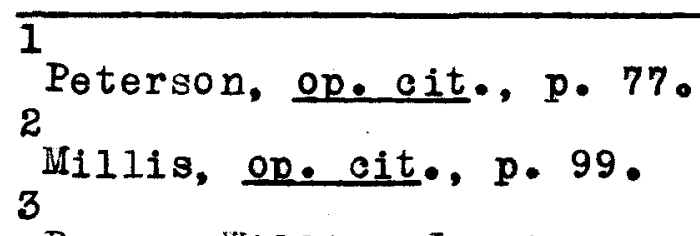

Bryan, William Jennings and hary Baird: The Memoirs of William Jennings Bryan, p. 395. 
resolutely against ang action which would be clearly a violation 1

of American neutralitj.

Our growing trade with England had its repercassions

in Germany, and $\mathbb{H} r$. Gerard, our ambassad or in Berlin, repprted that "my job is made harder by these sales of munitions"; a growing bitterness toward the United States was not difficult to detect in the Central Powers.

If he could not stop the trading now going on with warring nations, then he might stop the possibility of any loans to these nations, was the attitude of Secretary Bryan. In a letter to the President, August 10, 1914, Bryan wrote:

"Mone is the worst of all contraband because it commands every thing else.... If we approved of such loans.... our citizens would be divided into groups, each group loaning money to the country which it favors and this money could not be furnished wi thout expressions of sympathy.... The powerful financial interests which would be connected with these loans would be tempted to $s$ upport the interests of the government to which they loaned." 3

Once again Secretary Bryan was attempting to lead the government into making its ow international law, for international law does not require of the ne utral sovereign that he should keep the citizen or sabject within the same strict lines of eeutrality

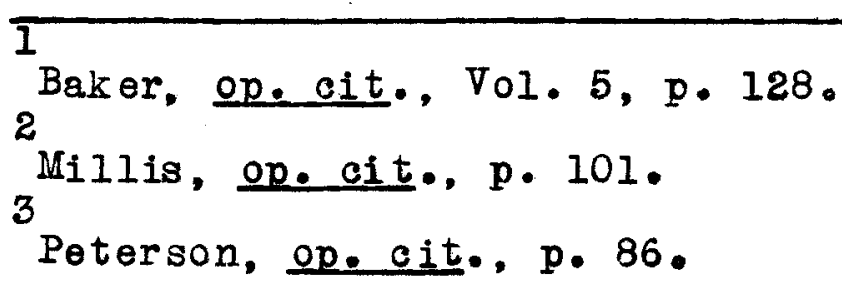


Whioh he is bound to maintain for himself. "The private person, if the law of his own state or some special treaty does not forbid, can lend money to the enemy of a state at peace with his own country for purposes of war, or can enter into its services as a soldier, without involving the government of his country in guilt." The editor of the Springfield Republican knew his law:

"That our govermment is meking the international law of the future by its disapproval of loans to nations at war is the opinion of the Springfield Republican, which reminds us that the present law does not forbid loans of money to a belligerent state by private citizens of neutral states." 2

On Angust 15, 1914 the announcement of the President's policy, in regard to loans to a nation at war, was telegraphed to J. P. Morgan and Company.

"There is no reason why loans should not be made to the governments of ne utral nations, but in the judgement of this governinent, loans by American bankers to any foreign government which is at war are inconsistent with the true spirit of neutrality." 3

In consequence of this announcement no loans were made at that time.

But on October 23, a technical distinction between loans

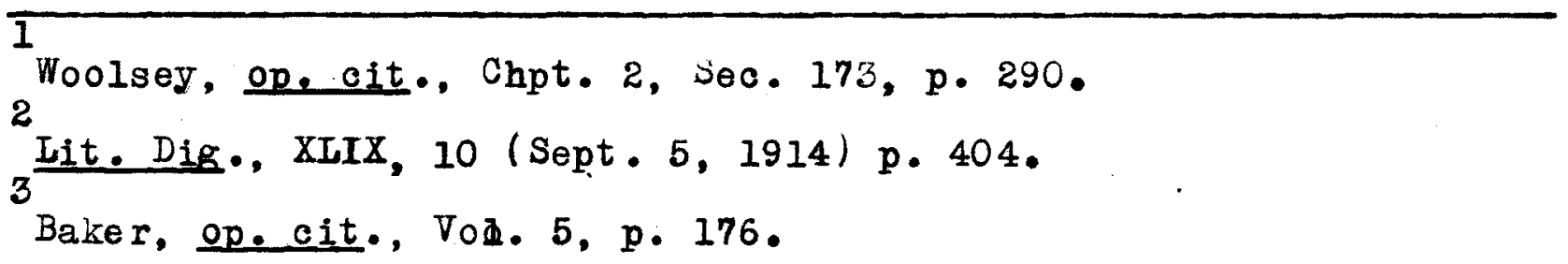


and bank credits was made following advice to the President by Robert Lansing, advisor to the State Departire nt.

"... Since the beginning of the war. I am informed that one bank al one has received cabled instructions for the payment of more than $\$ 50,000,000$ for Amerioan goods and that the volume of this business is inc reasing. Owing to war conditions, this buying is necessarily for cash and it is of such magnitude that the cash credits of the European governments are being fast depleted. Lately it has been arged by certain manufacturers and by represent atires of some of the foreign governments, that the baniks should provide temporary credits for these purchases

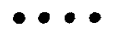

"... the oritical time for

American finance in our international relations is during the next three or four months and, if we allow these purchases to go elsewhere, we will have neglected our foreigh trade at the $t$ ime of our greatest need and greatest opportunity....

"For the purpose of enabling

European governments to make cash payments, it is suggested to grant to them short time banking credits, to both belligerent and neutral governments, and when necessary or desirable replenish their cash balances on this side by the purchase of short time Treasury warrants." 1

With Allied credits established, the "opportunity" for increasing our foreign trade that fir. Lansing stated, was not long In coming. 'Lrade with the Allied countries increased approximately 141 percent from 1914 to 1915. After 1915 the outstanding indebted ness of the Allies in the United States was inereasing by leaps 1

Baker, op. cit., Vol. 5, p. 186. 
and bounds. 'The Wew York press, with the notable exception of the Hearst and the German-language papers, gave the loan stalwart 1 s upport.

The general sentiment of the ration for the remainder of the year seemed to be peace and prosperity which the New York itimes summed up in a New Years Day, 1915, editorial:

"... The promise of the new year is that we shall accomplish a peaceful penetration of the world's markets to an extent we have never dreamed of. What others have shed bl ood to obtain through politics and force we shall attain while bestowing our benevolence.

".... It is a new translation of

the old beatitude, revised; 'Blessed are

the ire epers of the peace for prosperity shall be within their homes and palaces.' 2

The Times was wrong. Prosperity did come, but not through peace. Uredits to the British government created prosperity. for the American businessman, farmer and worker and editorial pages were reflecting the general trend of good times. The New York American called the surge of prosperity "our financial emancipation from the European straggle." But few looked far enough ahead to realize what would happen to the American prosperity bubble when the credits ran out. These credits by banks hampered the Federal Reserve System but bond loans, if permitted, would remove the problem. Mor-

$\overline{1}$

Peterson, op. cit., pp. 92, 103. 2

Iit. Dif., I, $2(\operatorname{Jan} \cdot 9,1915) \mathrm{p} \cdot 39$ 。

Ibiā, 16 (April 17, 1915) p. 859. 
gan once again requested a ruling from the President on the feasibility of loans and this time Lansing answered via memorandum stating that such loans were permissible as there was a difference between the "true spirit of neutrality" and "strict legality." There is no record of a written discussion by the President and his advisors but the situation was discussed.

The Uorgan Company signed a contract with the reading Commission on September 25, 1915. The loan was for $\$ 500,000,000$ and it was issued wi th a two per cent "spread" through a syngicate of sixty-one New York Houses with 1,500 members throughout the country, and hence to thousands of individual investors. Chicago, the financial capital of the diddle West with a considerable German population, remained cool. The only serious attack upon the loan, however, was on grounds, not of national policy, but of financial safety. This was met by the argument that the Allies did not really need money but only foreign exchange. This same argument was used to put pressure on the government. When on October 14, the books were closed, the somewhat ticislish situation had proved a success. Spring Rice, the British ambassador, stated in one of his reports ${ }_{k}$ concerning the loan: "When it became apparent that a loan was necessary in order to give credit for American $\overline{1}$ 2

Baker, op. cit., Vol. 4, p. 187 . Millis, op. cit., p. 221. 
exports to Europe, many secret forces began to act in its favor. The Government itself undoubtedly wished it, mainly because a continuance of American trade depended upon a credit."

Soon American ships were carrying practically nothing but British supplies. Business with the Allied powers grew by leaps and bounds, wi th but onecloud on the horizon; the war might end. Every time there was talk of peace, munitions stocks went down from five to 40 per cent. war had brought us prosperity, peace threatened to bring calamity. Gradually other worries began to trouble American ind ustry and finance. Suppose the Germans won-what then? "No, that could never happen. We have the word of A.D. Moyes, financial editor of the New York limes, that WaIl Street picked the Allies to win at the very start and never wavered in this firm belief."

The stock market reports throughout 1916 reveal strikingly the close economic relationship between the United States and the Allies. The news of the German victory at Jutland caused a big drop in the mariet while the exploits of the U-53 (submarine) created a temporary panic in which $\$ 500,000,000$ was lost in 15 minutes. Early in December the New York Times recorded that the German peace offer had sent all stocks down. The next day prices

1 Millis, op. cit., p. 220. 2 Engelbrecht, H. D. and Hanighen, F. C.: Merchants of Death, pp. 174-175. 
arose because there was no fear of "peace." At the time of the Wilson peace offer, the Pines stated: "Sales of more than 300,000 shares force most violent slump known in fifteen years." ${ }^{1}$ Bankor credits were sharply curtailed, and the Allied governments were able to renew their bills with the most extreme difficulty. The news of the diplometic break with Germany on the 4 th of February, 1917, sent Bethlehem steel ap 30 points. Mra Henry P. Davidson, a partner in J. P. Morgan and Company, had been one of the mast active opponents of Germany's "insincere" peace offers; he had wished for Anerican participation in the war in order to "cleanse us from our self-righteousness. ${ }^{2}$

The cott on market also followed the stock market in the fear that war might end. By January, 1915, the price of cotton began gradually to rise, and continued until the fall of 1916 , when the German peace proposal caused uncertainty again. On February 3, the day after diplonatic relations with Gernany were severed, the price began to rise sharply and the advance continued until the spring of 1918, when government price regulations were threatened and later inaugurated. For the greater part of the period from July 27,1914 to February 3, 1917, prices were below the 1913 average.

\footnotetext{
1 2

Peterson, op. cit., p. 267.

Lasswe 11, op. cit., pp. 78-79. 3

Baruch, Bernard M.: Ame rican Industry in the War, p. 245.
} 
Thus America was lending herself prosperity; a prosperity which in the end many economists believe can be nothing but false encomy and with the mast dangerous form of lending money known to finane iers; the lending of money by private indi viduals to a foreign nation. 'l'he loan maspbe considered purely a private transaction, without political considerations, but when default occurs, it may result in governmental action. An important source of friction in intermational relations arises from the use of the diplomatic machine to assist nations in collecting debts.

The September issue of IaDollette's Magazine (published and edited by Senator Robert $\mathbb{M}$. La Follette, Wisconsin) carried a caustic editorial:
"With the first clash of the great European war came President Wil- son's solemn appeal....'The United States must be neutral in fact as well as in name .... But when you can boom stocks 600 per cent in nufacturing munitions -- to the Bot tomless Pit with neutrality! What do Morgan and Schwab care for world peace when there are big profits in world war?.... The stocks of the Schwab proper- ties wich stood at a mariret value of seven millions before they began supplying the Allies.... are today given an aggre- gate 'value' of forty-nine millions. And now. we are about to engage in furnishing the Allies fands.... We are underwriting the success of the cause of the Allies. We have ceased to be 'neutral in fact as well as in name. " 2

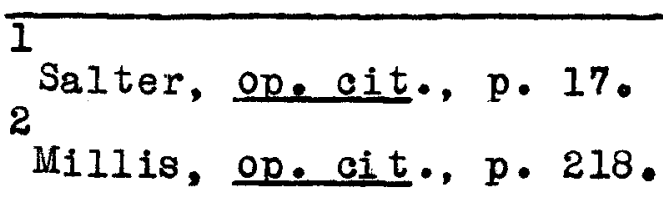


The last statement was probably true for a considerable number of Americans. Throughout the summer prosperity had been rising in an ever dizzier curve; by September the steel trade had "never seen demand so overwhelming and at the same times its output expanding on such a scale under steadily rising prices", by October the railway terminas, both east and west, were beginning to break down under a greater jam of traffic than had been witnessed in the most prosperous years of the past.

Not until the closing days of 1914, and not strongly until the following spring was the suggestion pushed that the United States by a threat of embargo on war materials might force the British to abandon those drastic interferences wi th ne utral trade which were illegal in the eyes of the American government. Apparently we did not recognize the international significance of our immense economic power, and we probably could not have used it, if we had, since embargoes would have resulted in an economic shock that American business was unprepared to withstand either by knowledge, or vision, or fortitade. Woreover, in the hope that the war would soon end-- or yield to the President's efforts to bring about peace-- there always lurked an excuse for avoiding drastic measures. Thus by the end of the year 1914 the traffic in war materials with the Allies had become deep Iy entrenched in America's economic organization, and the I

Millis, op. ait., p. 218 . 
possibility of keeping out of the war by the diplonacy of neu1 trality, was greatly reduced.

Despite the financial backing and the steady stream of war materials flowing to the Allies, the amount of American materials reaching the German army through ne utral European nations enraged the British. Gemany had been cut off from the direct purchase of American go ods by the British Navy, but a trickle of supplies cont inued to reach them. These goods were furnished by European neutrals by one of two methods; first, the direct reexportation of materials imported from abroad which formed a considerable volume of the trade of Germany and the neutrals and which had by no means ceased. 'the second form was the export of domestic products and the filling of the deficit by imoortation from abroad, mainly from the united States, desoite the fact that they had promised that no material imported from America would be exported to Germany.

The British answer to this situation was the contraband list; a long list of materials which might be used in furTHeaing German war aims, were not to be shipped by American merchants to European neutrals. This seemed a bold stroke but when one is involved in making war, any action to further oxk own aims is considered justifiable. With the list came a warning

\footnotetext{
$\overline{1}$ Baker, op. cit., Vol. 5, p. 181. 2

Clark, J. Maurice: Hamilton, Walton H.; and Moulton, Harold G.: Readings in the Economics of War, p. 285 (adapted from, Moore, James Louis, The New York Times, Aug ust 19, 1917).
} 
from the British that all merchant ships going to Europe would be seized and searched and contraband would be taken over and fair remuneration given. But still Britian had to be careful not to antagonize Ámerica too far. Perhaps nothing in the early days of the war en raged the british military chiefs more than the fact that cotton was permitted to go from the United States to Germany. That Germany was using this cotton in the manufacture of torpedos to sink British ships and projectiles to kill British soldeirs in trenches. was well known; nor did many people deny that Great Britian had the right to put cotton on the contraband list. Yet, Sir Edward Grey, the British foreign minister, in the pursuit of his larger end $r$ refused to take this step. He knew that the prosperity of the Southern states depended exclasively upon the cotton crop. He also knew that the South had raised the 1914 crop with no knowledge that a war was impending and that to deny the southern planters their usual access to the Germen marikets would all but ruin them. He believed that such a ruling would immediately alienate the sympathy of a large section - of the United States and me our southern Senators and Congressmen enemies of Great Britian. For this reason he did not declare 1 cott on contraband until August 20, 1915. The South was immediately alarmea, one reason being the 1914 crop-- 2,000,000 more bales than usual. Secretary of the l'reasury McAdoo met the situation 1

Hendrick, Burton J.: The Iife and Letters of Walter H. Page, Vol. 1, p. 367 . 2 Baruch, op. cit., p. 245 . 
by issuing a statement to the press to the effect that the Treasury would deposit, if it shoua become necessary, $\$ 30,000,000$ or more in Southern Federal Reserve Banis for loans on cotton warehouse certificates (August 23, 1915).

It appeared as if relations between the United States and Great Britian might become strained on the question of neutral trade and the examination of the mails. Even the cartoonists were beginning to sharpen their peneils with a new, though still friend18 asperit $\bar{J}_{1}$ and John Bull's rotund form began to appear in our papers, often with a string of stolen American cargoes under his arm, in attitudes less than. he roic. "Thousands of American importers," as Mr. Lansing wrote Mr. Page, were clamoring to the State Department against the British stoppage of cargoes from Germany. They were threatening to hold ms meetings to "denounce the dictatorial and illegal policy of Great Britian toward the United States" and lobbying for an export embargo as long as Great Britain continued to treat them "with contumely and contempt."

On December 3, 1914, Ambassador Page was bluntly informed that there was "sharp criticism in this country" of British high-handedness, a no that some thing wo uld have to be done. This new stiffness at last appears to have prodaed Page into some realization of the true position and he replied on December 7, with

\section{$\overline{1}$}

Baker, op. cit., Vol. 5, p. 378 . 2

Allen, George H. and others: The Great War, Vol. 4, pp. 374-375. 3 Millis, op. cit., p. 222. 
a proposed "working arrangement" with Great Brittin. The press of the nation was also split on the question of what to do. The New Yorker Herold (German language) labeled our unrestricted trade with the Allies "dollar diplomacy" and added that "all the powder and gun factories of the entire land a re working at breaknecir sped, f'or whom?...."They requested that all readers write to the ir representatives to force the government (to act) and hinted that "American arms-manufacturers don't care now whether there's a revolution in Mexico or not." ${ }^{2}$ But the jority of the Ame rican press backed the President for his stand and the New York Morning 'l'elegraph commented that it was the "frank belief of many along shore that the British admiralty, under the guise of guarding British interests is making an extension of American ocean trade as difficult as possible." ${ }^{3}$

As the full effect of the British stand became apparent to the American public the Iiterary Digest reported that "our press as a whole is by no means willing to accept Sir Edward Grey's statement of fact at its face value or to consider his arguments conciusive." The washington Past was very indignant. "Just as Germany destroyed Belgium on the plea of military necessity, England proposes to destroy American commerce." A few of the press, mostly from the pro-British section of the nation, could see a

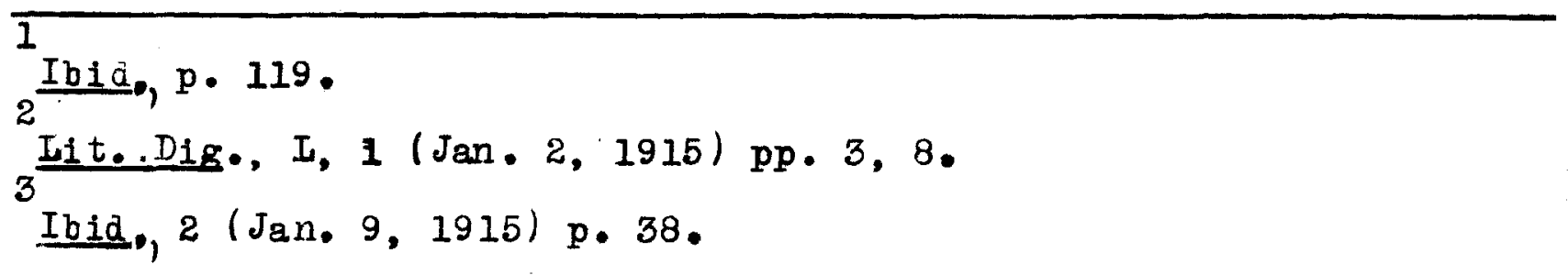


silver lining in Grey's reply and hinted to the public that "the note gives promise of an early and satisfactory understanding." Only two members of the fourth estate, the New Haven Journal-Courier and the Wall Street Journal believed the answer satisfactory. At $b$ oth end $s$ of the At lantic passage, American trade with the Central Powers was subject before the end of 1914 to a "voluntary system" of British supervision as astonishing in its extent as it was probably abhorrent both to domestic and international law. "One hesitates to think of the storm of popular outrage which would have resulted had the Germans been in a posi tion to exert one tenth of the interference which was scarcely noticed when practiced by the Allies. "

But the possibility of an. outbreak with Great Britain due to the hampering of our commercial relations with the Central Bowers was averted-- not by a relaxing of British restrictions or a change of heart of the American public and governinent-- but by the short-sightedness of Gerrany. For on February 5, 1915, the newspapers of the United States were blazing with the headline: German Proolaims a War Zone. At the orecise moment when American resentment against the British trade controls might conceivably have produced some tangible results the Gerinans had created a diversion in which all tought of the trade controversy was soon to be swallowed up and lost.

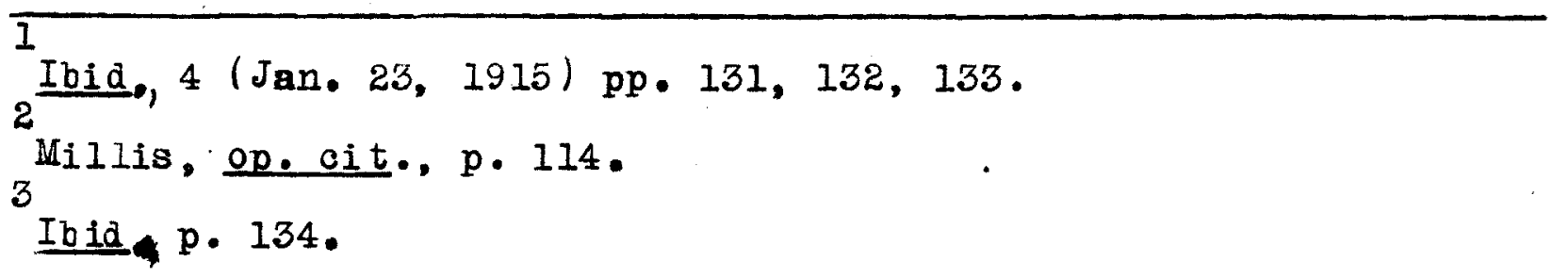


The British overlooked nothing in an attempt to bring American industrial might behind them. At the annual convention of the American Federation of Labor in the fall of 1914, the regularly accredited delegates from the British I'rades Union Congress, who usully came, were missing; in their stead, however, there turned up "two British labor men," Mr. Janes Seddon and Mr. Albert Bellamy, who were eagerly received and questioned about the war by the American labor chieftains." Whether the British labor representatives tipped the balance or completely ohanged the opinions of Anerican Labor leaders is uncertain, but at least the results were the same. Many of the labor groups, which were eyed with suspicion because of their supposed disinclination to prosecute the "Capitalists' war," as agitators called it, were similarly eager to display their patriotism. When a big munitions strike broke out in the Bridgeport factories, in 1915, Samuel Gompers, head of the Anerican Federation of Labor, sushed off at once to stop it and so "protect the good name and safety of the labor movement."

With the break off of diplonatic relations following the unrestricted submarine warfare note, February 3, 1917, Mr. Gompers cabled Carl Legien, the president of the lerman Trades. Union Federation, demanding that he put pressure on his government to halt submarine warfare; and when the German presently responded with 1

2 Ibid, p. 65 .

Ibid., 
the suggestion that $M r$. Gompers put pressure on England to raise the food blockade, the great American labor leader felt that Leigen's answer was a patent "evasion of duty." The four Railroad Brotherhoods announced on Lar on 10, 1917 that their threatened strike would be called off in the event of war and there were some longshorement and munition worker's strizes of considerable proportions; but it seems rather doubtful that labor's National Peace Council could rightly claim credit for them.

The huge volume of business enjoyed by the United States during the last year of neutrality helps to explain why no military action or economic sanctions were taken against Great Britain for her contraband list and her censoring of mail. Exports jumped from over two and one-half million dollars to four and one-third billion. The war economics as a whole made the United States a financial, if not a political, ally of Great Britain and France. As soon as the lermans struck back at the blockade and the utilization of the New World as a base of supplies, they found themselves confronted not only by the might of Great Britian and her allies, but also by that of the united states. As far as the economic warfare was concerned, the A rerican declaration of war took place in 5 1915 .

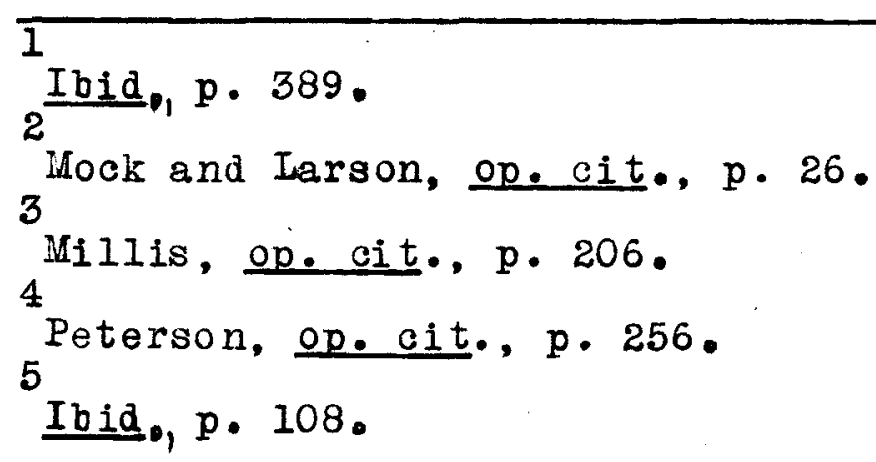


ivar costs money, and the expense falls by no means wholly on the belligerents. If the European conflict brought the United States industrial prosperity, it also imposed-- even in the years of neutrality-- a heary fiscal burden. On the one hand, the army, the navy, the merchant marine and ot her services called for increased outlays; on the other, diminished inports out off customs receipts, with 1915 being the smallest year since 1899, but thereafter until shortly after the close of the war governmental revenue showed a steady increase.

Each time that the Berlin Governinent made a concession to the United States, such as warning before sinking, it expected that Washington would for ce coresponding concessions from the Allies. But the united States possessed no means of bringing effective pressure to bear upon the Allies wi thout injuring so deeply its own commercial interest thet the price seemed too high to pay. As was explained by Secretary Lansing, in his reply to the Austrian protest, August 12, 1915, the United States, accustomed to rely on small defensive forces and on the right and power to purchase arms and ammunition from ne utral nations in case of foreign attaci, was the last nation in the world that could afford to establish a precedent of the kind that was asked.

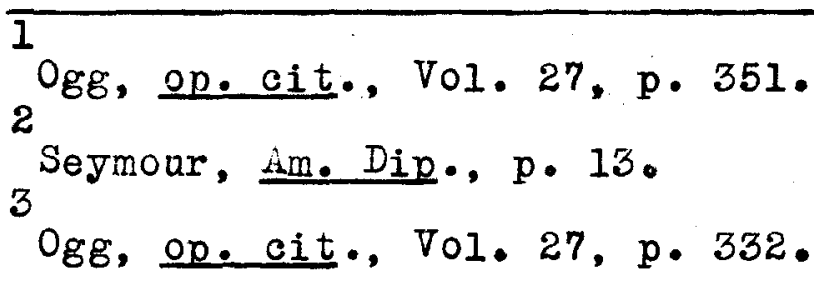


Most of the restrictions that appeared likely to touch American interests were gradually arranged by private negotiations. Certainly commerce and trade were never more profitable for Americans. The Allied command of the sea, on the whole, was not exercised in a way seriously to injure American pocisets, but it did injure American pride.

The declaration of the unrestricted subarine warfare in January, 1917, proved the straw that broke the back of American ne utrality.

Business interests were bound up with the maintenance of foreign trade which was controlled by the Allies. But this fact by no means justifies the belief that those interests forced the United States into the war. From the economic point of view continued neutrality was for them the most desirable goal, just as for Wilson it was the main political purpose. If conditions of neatrality had remained bearable there would have been no intervention.

\section{$-0$}

$\overline{1}$

Seymour, Am. Dip., p. 44 .

Ibid., pp. 24-25. 
VI. CONCLUSION.

War is not "inevitable," but proceeds from definite and removable causes.

G. Iowes Dickinson 
At the onset of the European struggle the fact was clear that the American people would find it more than ordinairily difficult to avoid taking sides as this was a Norld War; and the United States, the historic asylum of the oppressed, contained a "menagerie of nationalities, $n^{1}$ But this did not mean that the American people wanted to get into the fight, nor did it mean that they now loved Great Britain. Although the mority of those who took sides seem to have favored the Allies, this feeling was probably more anti-German than pro-British.

The popular American conception that neutrality is a clearly defined status is erroneous. On the contrary, we shall come closer to a correct view if we think of neutrality merely as a policy, which, within certain limits, has an almost infinite number of phemutations and combinations. No two authorities can agree on a definition of the precise rights and duties of neutrals, except as regards specific and (for us) minor matters such as the withholding of direct aid by a neutral nation to a belligerent, or the duty of a neutral government to refuse to allow its territory to be used as a base for military operations against a belligerent. The trade rights of a neutral are as broad as the power the ne utral

1

Bailey, Thomas A.: A Diplomatic History of the American People, p. 610 . 2

Of the 367 editors who replied to a Iit. Dig. poll, 20 favored the lermans, 105 the Allies, and 242 neutrality; XIIX, 20 (Nov. 14. 1914) p. 939. 
is willing and able to assert to maintain those rights. Neutrality should mean that policy which a country at peace adopts toward countries at war.

In the opening decade of the twentieth century, unbeknownst to many Americans, the United States had become a world power. 'the country's foreign trade had been growing by leaps and bounàs; by 1913 exports reached a value of nearly two and a half billion dollars. Lxports which bulked so large in the national economy exercised, of course, a corresponding important political influence at Washington. There are many writers who attribute America's entry into the war solely or largely to these financial bonds by which she was bound to the Allies, and to the foreign propaganda by which she was duped; but these forces nust not be over-emphasized. Host Americans favored the Allies before the war orders arrived or the loans were floated, and the loans were as much an expression of sympathy as a mere business transaction. In 1915 the Germans, too, tried to borrow in this country; but only a few German-Americans lent, though the German armies were then victorious on every front.

Mr. Millis, in his interesting book, gives us the impression that the United States was caugh in the world war primarily

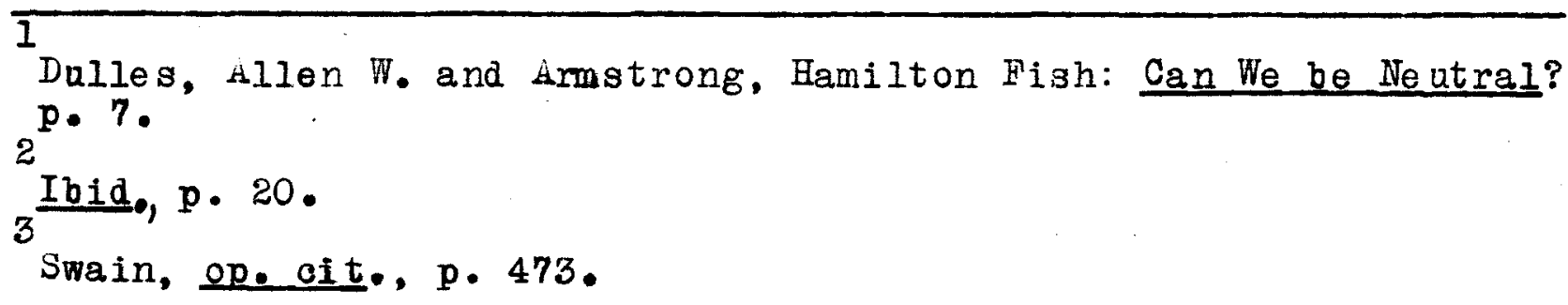


because of the preponderance of British propaganda, the subleties of British diplomey, and the influence of vested financial, commercial and industrial interests whose fortunes became tied up with an Allied victory. These factors all counted. But to single them out and stress them so heavily seems to us to allow too little for the ratural predisposition of many dmericans for certain principles and the ir antipathy for certain others. Mr. Millis tends to ignore the fundamental reasons why American sentiment turned in favor of the Allies and against Gemany. It is not necessary to hunt for a demon either in Wall Street or in Downing Street to explain the Ame rican attitude toward the war. Whatever may have been the effect of hired propaganda or the influenee of financial and commercial interests, they do not fully account for our intervention.

1

Dulles and Armstrong, op. cit., p. 22; Thus one looks in vain for a reference to the fact that there was a treaty guarantoeing Belgium, that Germany had signed it, and that Gemany's violation of it exercised an instantanceous and persistent effect on American feeling toward Germany. The Belgian deportations are called "an attack upon the unemployment problem in Belgium and Northern France"; it is not mentioned that in 1917 Germany ordered the stoppage of all public works undertaken by the belgian communes and provinces for the relief of unemployment, that she had already removed to Germany many of the instruments and machines of labor, that the forced labor to which the deportees were condemned was wor $k$ for the enemy, often on military roads and trenches. near the front, that hence the Belgians were willing to suffer punishment and go into exile rather than work, and that many Americans pitied and applauded them. When $M_{r}$. Millis describes the staff of the American Iegation in Brussels and the Ame rican corre pondents as naive for not emphasizing that Belgian francs tireurs were technically guilty of atrocities in sniping at the invading troops and that the Geman high command was technically justified in lining up local hostages and shooting them, he misses the point; 
There can be no doubt that there was much Allied propaganda; but there is considerable doubt as to its effect. It seems reasonably clear that American opinion was anti-German before the war began; it also seems clear that American opinion was outraged by the acts of Germany. Belgium was a fact; the Iusitania was a fact. And although sritish propaganōa unquestionably embellished these facts, its effect would have been incomparably weaker with out them.

We were unprepared as a people and as a government to deal with the conditions created by a general Duropean war. There was no time in the sumrer of 1914 to sit down quietly to weigh the consequences of alternative courses to meet a situation which daily became more complicated, much less to think out a \$ong-range policy. All that our govemment could do was cling to the best precedents available, even though second thought might have raised doubts as to whether they really were applicable to the new conditions of maritime warfare, especially when the war was being waged by the mighty antagonists now locred in a death grip. We stuok to

no emphasis on the illegality of the Belgian civilians action or the legality of the German military reprisals would have made the American public of that day feel that the Belgian defenders were not acting heroically and justifiably and that the German invaders were not acting in a contrary sense. Other cases could be cited of failure to appreciate the origins of the sentiment which as the war developed played an important part in shaping American policj. The hostile and criminal acts of German agents in the United states irritated the public much more than Mr. Millis can remember-- and were placed in a different category from the propaganda and publicity work of Allied writers and lecturers. It seems to us unrealistic to imagine that deep-rooted sentiment can be dismissed as an important factor in determining the policies of nations; perhaps, it is unjustified to assume that its elimination is necessarily desirable, even though one can prove in spe1 cific cases it might well be.

Bailey, ㅇp. cit., p. 613 . 
the precedents; and they led us step by step nearer the arena. What really happened was that from the very beginning of the war American sympathies were engaged. On top of that, and of decisive importance, the course which the Gorernment took in demanding observance of its traditional neutral rights engaged the national honor of the United States in the defense of the principle that its trade should cont inue and that its nationals were entitled to protection in the exercise of that trade. When those rights were curtailed by Great Britian, we protested. When our citizens who were exercising those rights were killed by Gerinany, when our ships were sunk, and when Germany formally challenged our asserted rights, then we went to war. If the basic conception of our policy was sound, what other course in self-respect could we have followed? Americans sometines have vague preferences among foreign countries. 'though some persons found deep reasons for these perferences, many who loudy preferred one country to another based their choice upon nothing more important than tradition, or the food and treatment accorded to them in the hotels and trains of various countries they had visited. England was the country that loomed largest in the American mind, and aristocratic "Anglomaniacs" admired her tremenduously; the common language and traditions, and the idea of Anglo-Saxon solidarity, impressed many; the English and Scotch immigrants in America gen rally retained a kindly feeling for the mother country. But England was also the most hated nation; many people considered it a matter of patriotism to hate the former mother coun- 
try-- a sentiment which the millions of Irish never allowed to grow cold.

The German immigrants were equally well disposed towards their former Fatherland, while many intellectual leaders in America had been trained in German universities, and admired Germany's. achievements in science and social reform.

Even the Irish did not curse the government from which they fled more bitterly than did the Russian Jews in America. In the days just before the war, my Americans thought of France more favorably than in earlier jears; but in regard to the other countries of Europe people were ignorant and apathetic.

Sir Edward Grey knew his history:

"Relations with the United States differ from those of Great Britain with

any other country. The two countries have one language in common, and the jurisprudence of both is founded upon the com-

mon law of England. The American consti tution was drawn up and made by men of British race, whose descendants form a large part of the present population of the United States and are still proud of their race and conscious of the kinship in blood and the common origin and traditions. The whole people are attached to democratic governme nt and human freedom."

Sir Edward added, however:

"The sense of common race and origin is closely associated with the historical memory of bitter war. americans do not always seem to realize that those who left Britain to escape from King and prelates

1 2

Swa in, op. cit., p. 474 .

Ioc. cit. 


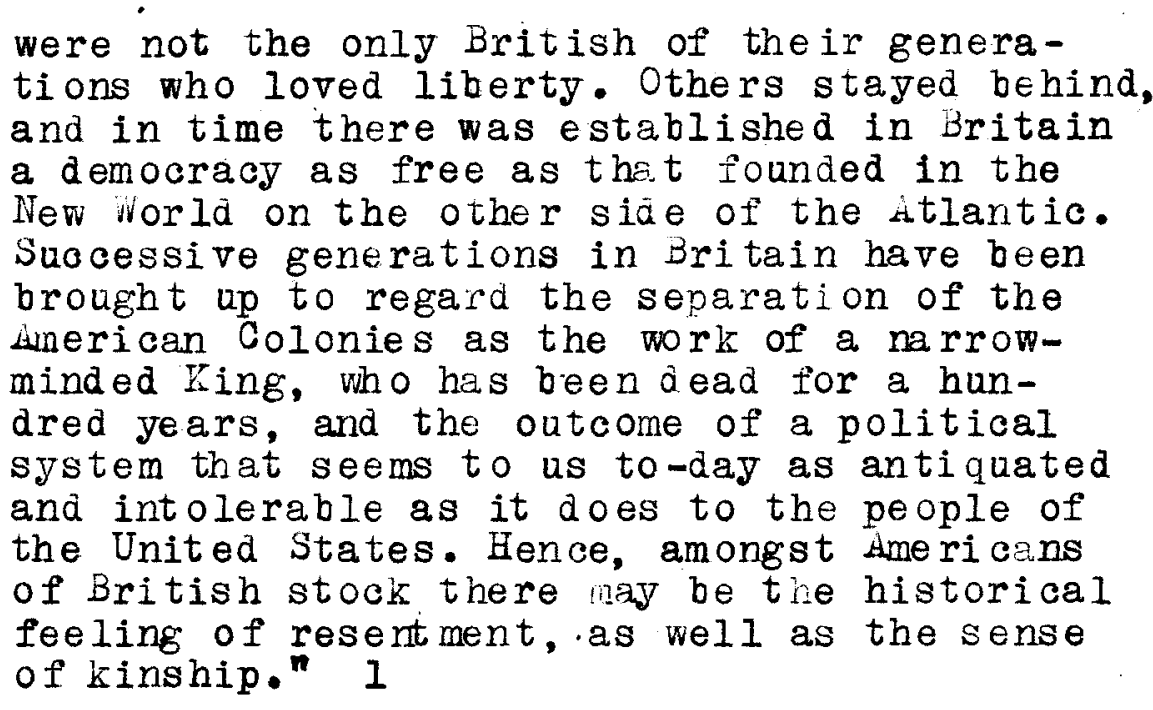

Hence, the pro-British sentiment had little effect on public opinion, however it may have influenced our statesmen as the dilson administration showed pro-Ally leanings with the exception of the Secretary of State, William Jennings Bryan, who was considered by his colleagues as pro-German. Wilson himself was of British ancestry, and a strong admirer of British culture. He made a genuine effort to pursue a strictly neutral course, bat as the war progressed he found his sympathies gravitating more and more to the side of the Allies, and occasionally in private he would betray himself. Once he burst out, "England is fighting our fight."

Robert Iansing, who replaced Bryan as Secretary of State, in his me morandum, "Consideration and Outline of Politics," written

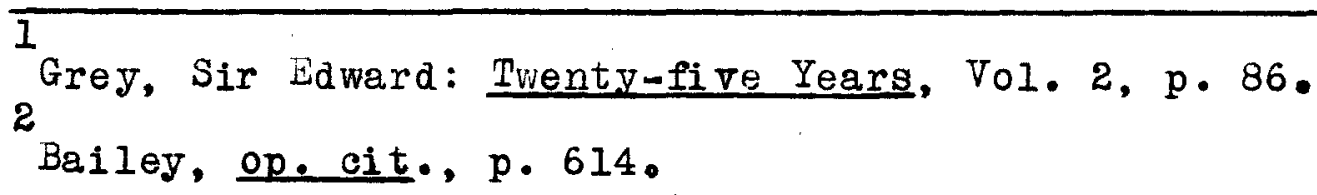


July 11, 1915, said:

"American public opinion mast be prepared for the time, which may come, when we will have to cast aside our neutrality and become one of the champions of democracy." 1

Iansing also adnits that he intentionally held up and prolonged the disputes to see if something could happen to change public opinion before an answer had to be sent.

The President's most trusted advisor, Col. Edward $M$. House, was strongly pro-Ally. Ambassador Page in Englana was so pro-British that instead of representing the United States in England, Page represented the British cause to the government in Washington.

But these members of the administration were not the nation, although holding positions which might influence the nation. The East was pro-British, the middle West neutral and the far West did not seem to care. Sensing the policy of the rion, Wilson on August 4, when five nations had entered the struggle, issued a formal declaration of neutrality, which was repeated as successive states entered the contest; and two weeks later he made a special appeal to his fellow citizens to be "neutral in fact as well as in name.... We must be impartial in thought as well as in action."

1

2 War Memories of Robert Lansing, p. 21.

Ibid, p. 112 .

Bailey, op.cit., p. 620 .

Ogg, op. cit., Vol. 27, p. 329. 
With our neatrality proclaimed we started out with the idea that there must be certain inherent rights of trade, a thesis which we consistently intained throughout our history. Iike his predecessoss-- Washington, Adams, Jefferson and Iladis on-- President Wilson was soon engaged in the effort to keep out of war, maintain neutrality, and at the sane time make good the illusive and indefinite doctrine know as the Freedom of the Seas. But now there was no serious question of embargoes or non-intercourse as in the days of Jefrerson; trade was too important. When Congress met in December 1914, bills were introduced to embargo the export of arms and ammunition, one of them sponsored by an influential Democrat, Senatof Hitchcock of Nebraska. The influences wich prevented its adoption were not prinarily comnercial. The bill suffered from being presented as a humanitarian measure rather than as a move to keep us out of the war, and it was attaked and defeated as preparing an "unneutral" change in our laws after a foreign conflict had begun. Nevertheless, the fact that our people had never doubted their right and ability to continue trade with belligerents and still remain neutral, and the fact that the relinquishment of that trade wo uld have played havoc with many fundamental American occupations, were root causes of our whole attitude. as a legal basis for the position we assumed we first tried to make use of the Declaration of London of 1909, which defined contraband and etc., but we felt deprived of its real value 1

Dulles and Armstrong, op. cit., p. 24. 
due to the knowledge that Great Britain had never ratified the declaration and refused to apply it without modifications. With this in mind we fell back upon what we claimed to be the recognized rules of international law. But in doing so we had to recognize that inter. nation l law failed to give us a definite code and that this failure would "andoubtedly be the source of numerous controversies." Further, particularly in our dealings with the British, the doctrines.we had maintained in the Civil War ame in to plague us. We had ourselves brodened the idea of "continuous voyage", the doctrine under which we seized goods which were enroute to a ne utral port but which we asserted had an ultimete enemy destination; and we had extended the list of contraband.

Our most serious admission was the cable from Secretary Brgan to Ambassador Page, December 26, 1914. "... that the commerce betwen countries which are not belligerents should not be interfered with by those at war unless such interference is manifestly an imperative necessity to protect their national safety, and then only to the extent that it is a necessity."

Three important problems faced President Vilson and his foreign policy during 1915; the English attempt to block indirect importation to Germany which he "violently opposed" in a series of notes, the lerman war zone around England when he informed the German government he would hold them to "striat accountability", and the sinking of the Iusitania.

$$
\overline{1}
$$

Baiker, op. cit., Vol. 5, p. 218. 2

Dulles and Armstrong, op. cit., pp. 26-27. 
It did not take the British long to reach the conclusion that the suppression of our trade with Germany was an imperative necessity. As Iord Grey stated: "The object of British diplonacy, therefore, was to secure the maximun of blockade that could be enforced wi thout a rupture with the United States." Even if the law had been different or our previous policy a reversal of this action, it is doubtful is the British would have relaxed their hold upon neatral commerce. They were sighting for their very lives; and to. them American profits were a minor consideration. British restrictions hurt both American pockets and American pride. Britain countered our notes by playing a delaying game, and the strategy was perfect and, what is more, the united States played the British game. The longer the State Department deferred pushing matters to a showdown, the more perfect the British strangulation of Gemany became and more closely the united States was bound by economic ties to the Allies, and the greater the chence that the German subnerines would drive the country to war.

It has frequently been al leged that the united States could have forced the Allies to respect its rights by instituting an embargo on war materials. Such a course was repeatediy proposed, but it met with considerable apathy. As the weers passed by, the

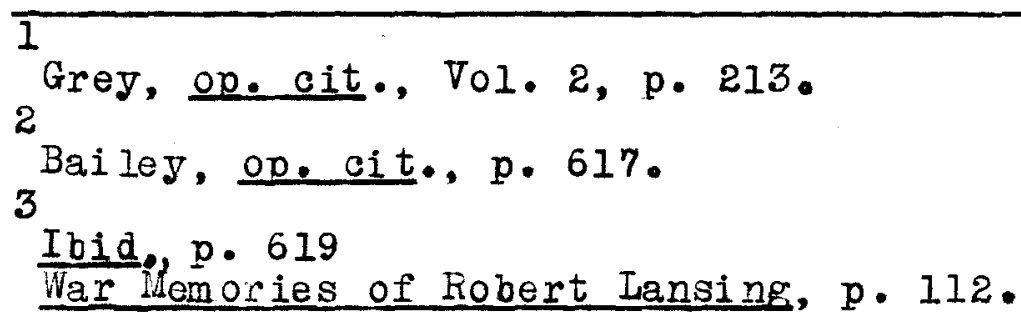


American economic structure gradually became so inextricably interlaced with the cause of the Allies that public opinion would not have to lerated an embargo. A Literary Digest poll, even at this early period, showed the industrial centers against $s$ uch a move. The United States to ok a position which was logical and which fitted both the sentimental and the national interests of the country, namely, that we were under no duty arbitrarily to rectify the consequences of British control of the sea. We would trade where we could, and thus fill the gaps caused by the loss of trade with Gerrany, whose ports, as well as the ports of neighboring countries, were largely closed to us as a result of the extension of the contraband list and the doctrine of continuous voyage. Further we considered it objectionable as a matter of principle to change what we conceived to be the rules of neatrality aring the course of the war. Thus Secretary Bryan wrote to Count vor Bernstorff on April 21, 1915:

. "... any change in 1ts own laws of neutrality during the progress of a war, which would affect une ually the relations of the United States with the nations at war would be an unjustifiable departure from the principles of strict ne utrality." 2

The United States had no objection to selling arms and ammunition to Gemany; but if she could not import them because of

\footnotetext{
I Iit. Dig., I, $6(F e b \cdot 6,1915)$ p. 225. "Papers relating to the Foreign Relations of the United States," 1915, Supplement, The Wor ld War, p. 162.
} 
the British navy, that was one of the misfortunes of war. In short, an embargo on munitions would favor lemany; the absence of one woula favor the Allies. So the United States followed the profitable path of least resistance.

The government therefore cont inved to pursue a policy that violated the true spirit though not the strict letter of neatrality; bound the nation ven tighter to the wheels of the Allied economic cheriot; and so inflemed the German mind as to provide a partial justification-- to the Germans at least-- for anrestricted submarine warfare. Therefore, when, Germany in February 1915 proclaimed that the waters surrounding Great Britain were to be considered within the seat of war our answer was Wilson's "strict accountability" note. We stated in that note that:

".... the Government of the United States would be constrained to hold the Imperial German Government to a strict accountability for such acts of their naval a uthorities and to take any steps it might be necessary to take to safeguard American lives and property and to secure to American citizens the full enjoyment of their acknowledged rights on the high seas." 2

There in $a_{3}$ few words, is the thesis which, logically pursued, led to war. It was stated before the blossoming of the

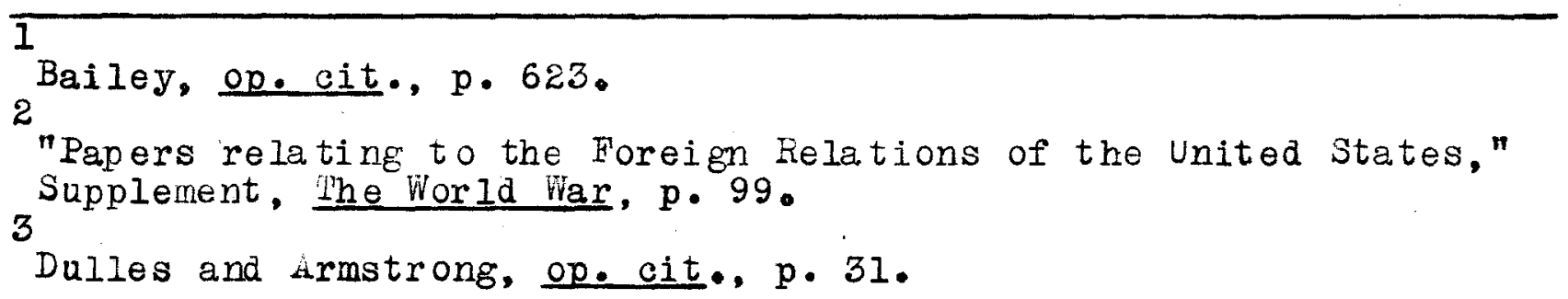


"var boom" based on trade with the sllies, and seven months before the first Allied public loan in this country. We were insisting on what we calfimed to be full enjoyment of acknowledged rights. In a note to Germany a few months later the same idea appears:

$$
\begin{aligned}
& \text { "The rights of ne utrals in time of war } \\
& \text { are based upon principle, not apon expediency, } \\
& \text { and the principles are immatable. It is the } \\
& \text { duty and obligation of belligerents to find } \\
& \text { a way to adapt the new circumstances to them. I }
\end{aligned}
$$

The sinking of the Lusitanie had consequehoes from which German diplomacy never recovered. It brought the war home to a mass of Americans for whom until then it had been little more than a moving picture. It made impossible any sort of understanding between the United St tes and Germany as against Allied interference with neutral trade. It raised definitely and for the first time the question of American participation in the war, and it pointed unequirocally to Germany as the enemy of the future. Wilson could have broken relations with Germany on the following day; he would have received a tamult of applause from the Eastern states and at least acquiescence from the rest of the country. His hesitancy was revealed in his "too proud to fight" speech, delivered at Philadelphia, three days after the sinking. Wilson immediately reiterated his statement of "strict accountabilit $\bar{J}^{\text {" and asked }}$ the German government's disavowal and the reply to Wilson, September, 1

"Papers relating to the Foreign Kelations of the United States," 1915, supplement, The World War, p. 481. 2

Sejmour, Am. Dip., pp. $89-90$. 
1915, promised no more sinkings without warnings, al though negotiations dragged on into 1916. The severity of the second note caused the resignation of Secretary of State Bryan.

Wilson's firm stand in his second note was proof that he was slowly refecting the pocifist attitude and that his patience was wearing thin. With the exception of the Hest, the newspapers were loud in praise of his action.

The las of the British liner Arabic, August 19, 1915, found Secretary Lansing seriously considering the severance of diplomatic relations, but Wilson, seemingly determined to bring about a peace conference, either by persuasion or threats, would not approve the action, fearing the country would not sustain the government. The out come of the incident was a Wilson victory. "The country is undoubtedly back of me in the whole metter, and I feel myseif under bonds to it to show patience to the atmost. My chief puzzle is to determine where patience ceases to be a virtue." Doring the seven months after the sinking of the Arabic, the German submaines refrained from killing American citizens. But a vast amount of suspicion and 111 feelings was created in the United States by the alleged machinetions of German secret agents, 1 Iit. Dig., I, 25 (June 19, 1915) pp. 1449-1450. 3 Seymour, Am. Dip., p. 130 。 Bailey, op. cit., p. 630 . 
particularly by their attempts to sabotage the munitions trade. Other incidents included the exposure of the Albert papers, the recalling, by request of $\mathrm{Dr}$. Constant in Dumba, the Austrian ambassador, charged with formenting strikes, and the recall by request, of Captains von Papen and Boy-Ed, December 1, 1915, for overstepping diplomatic boundaries in regard to the war effort. Although many of the alleged German plots were figments of fevered imainations, the witch hunting hysteria that swept the country deepened distrust of Germany, and further prejudiced the American mind against the Central Powers.

As a result of the prolonged Lusitania negotiations and internal disturbances it became clear to Wilson that if the war did not come to an end, American participation was almost unavoidable. Wilson's call for mediation, through his personal diplomat, Col. House, in January, 1915, and again one year later, was not the meddling of an interfering busybody or the dream of an impractical visionary. It was based upon the need of escapging from the antenable position of a ne utral. Ending the war by negotiation or entering the war were the only alternatives. On his second trip to Europe, Col. House, in his attempt to get a conference meeting of the powers, virtually pledged the United States to become a member of the Allied coalition. He had been told to pledge MORAL force.

\section{I}

Ibid, p. 632 。

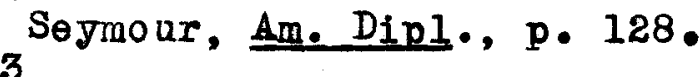

Bailey, op. cit., p. 635. 
The attempt failed as neither side was desirous of peace at that time.

The rejection of the peace plan, especially by the Allied powers, and the action of Congress on such bills as the McLemore bill, which would have forbidden Americans to sail on contrabandladen British liners (the bill was sidetracked following a strong message from Wilson) brought a lull in American action during the period from Febraary to May, 1916. It was a period of watchfal waiting •

But the period of watchful waiting ended with the torpedoing of the channel steamer, the Sussex, March 24, 1916, with the loss of American lives. Wilson's note, asking Germany to disavow was sent April 18, and the German reply, pledging restriction of subnarine warfare, arrived lay 4, 1916. It was a victory for Wilson. He averted hostilities, maintained American prestige and forced the Germans to emasculate their most effective sea weapon. But he took such a position that it would be virtually impossible honorably to avoid war if the Germans should reopen their unrestricted submarine warfare.

The same month (ifay, 1916) 135,000 people throughout the nation marched in "Preparedness Day Parades." Wilson carrying a flag led the Washington parade. This was Wilson's appeal to the general public, as he had already appealed to Congress (Dec. 8, $\overline{1}$

$$
\text { Ibid., p. } 636 \text {. }
$$


1914) stating that provision for coluntary military training would be extended, and that the organized militia of the states should be developed and strengthened. The war in Europe had proved the failure of a small army and Wilson wanted an improvement in our militia, without conscription.

During the nine months following the so-called Sassex pledge, the German submarines were on their good behavior as far as the United States was concerned. American pablic opinion was therefore left free to concentrate on the accumulation of grievances, old and new, at the hands of Britain. Particularly galling was the British practice of opening the United States mail, in search of contraband being sent to Germany. 'Lhe resentment of the Ame rican people was further increased when it as alleged that trade secrets were being filched from these letters and tarned over to British commercial rivals. Then on July 18, 1916, came the British blacklist, composed of 85 persons or firms, with whom the British were not to trade. This act angered the nation; even Wilson and the cabinet. The protest of the Washington government against the blacklist was based on international morals rather than on international law, for Britian had an undeniable legal right to forbid her subjects to trade with firms in the united States. The Democratic Convention meeting in St. Louis, June 14,

\footnotetext{
1

I1t. Dig., III, 22 (Mag 27, 1916) p. 1518. Bailey, op. cit., p. 636.
} 
1916, selected President Wilson to once again head the ticket. Backed by the slogan, "He kept us out of war," the convention attempted to make peace the theme of the campaign wi th diplomacy the weapon instead of war. The election campaign submerged the war issues on the sea. Wilson, of course, had promised nothing. The slogan referred only to the past, and was historically true, but there were those who felt that the slogan was a tacit pledge which wilson was morally bound to observe.

The Republicans, meeting in Chicago, selected a Justice of the Supreme Court, Charles Evans Hughes, as his opponent, although they failed to make a concete stand on the war situation. Obriously Wilson would head the ticket even if the politicians did not like him; apart from negligible elements alienated by his foreign policy, the rank and file were for him. Indeed, he was recognized to be stronger than his party, and it was assumed by Democrats that he would draw heavily from the Progressives and from the independent vote. Starting with a somewhat archaic Jeffersonian equipment of political principles, and under the suspicion of being a cloistered doctrinaire and amateur, he had proved himself a practical and adroit politician, and adept at divining the trend of public opinion, and a statesman capable of infusing the radical democratic impulses of Bryan into the ldealistic program 1 Ibid, p. 638 。 
1

of the moderate progressives. Hughes, the Republican candidate, hoped to bring back the Progressives who had split off in 1912, and most were ready to follow Teddy Roosevelt back into the fold. The elder Henry Morgenthda, writing in his book, All in a life-Time, remarks concerning the pessimism of the Democrats:

"I spent the first few days after my return to the United States with my old political friends in Washington and $I$ was shocked at the prevailing political atmosphere. Not one of the numerous. men high in the administration with whom I talked had the slightest hope that President Wils on could be reelected that fall." 2

Hughes made many criticisms of Wilson's conduct of foreign affairs, but his own policy was never clear. He was strong in the north-east, where pro-4lly sentiment was strong, but he failed to gain many German votes or to offset the Democrat's slogan; "He [Wilson] kept us out of war." The final outcome was close. New York went Republican, but the returns from the west finally sweng the tide to Wilson.

$\overline{1}$ 2 Ogg, op. cit., $\forall 01.27$, p. 374 . Baker, op. cit., Vol. 6, p. 34 . 
The Democratic victory was accomplished by inroads on Republican strength among the farming populations of the newer states. These inroads were easy to make, for the reason that these people regarded the President as a genuine progressive, and because they thoroughly approved his pacific foreign policy; Hughes, they considered to be the candidate of a party dominated by reactionaries and jingoes. The much feared "hyphen" vote failed to materialize. He had avoided war with Germany. Of seven states containing the largest numbers of German-Americans, the Democrats carried 1

three. Wilson was actualiy more favorable to Germany than the leading Republicans, especially The odore Roosevelt.

Following his reelection, according to Mrs. Edith Reid, a close Efriend of Wilson's, the president again was determined to bring about peace in Europe, if possible. "Now the burden upon me is heavier than ever," he stated. "If we can escape entering the war and bring about a rational peace it is something worth living and dging for, and I believe the country feels that way or it would not have re-elected me." ${ }^{2}$ But we must remember there might be times when the completion of a rational peace might require war.

Shortly following the election Germany made a move for a compromise peace, but the Allied answers showed peace impossible

$2_{\text {Ogg, on, cite, Vol. } 27, p .381 .}$
Millis, op.cit., p. 354.


without a decisive victory. Although Wils on had promised Germany to move for peace immediately following his re-election, he waited until after the German move, in the middle of December, to begin the writing of his peace notes, at which time (December 18) he sent identical notes to all the belligerent nations. The pablic reaction to Wilson's move followed the general pattern that had prevailed throughout the country following his previous attempts at mediation; a pro-Ally east, a neutral mid-west, a disinterested west and a drop on the stock exchange.

The German answer was at first evasive and the Allies refused to bargain without the certainty of reparations, cleverly concealing their answer, and realizing their goal of inciting farorable public reaction in the united States.

On January 22, 1917, Wilson gave his reaction to the replies of his peace message, in his "peace wi thout victory" speech to Congress and at the same time asking for a League of Nations to preserve peace in the future. It was a last desperate attempt to win peace for America. It was the final stage of American neutrality. $\overline{1}$

Baker, op. oit., Vol. 6, p. 434. 2 Bailey, op, cit., p. 640 . 3 Iit. Dig., IIV, 1 (Jan. 6, 1917) p. 24 . 4 Peterson, op. cit., p. 267. Baile 8, op. cit., p. 641. 
But Wils on was too late, for on January 8, 1917, the Emperor of Germany had secretly promulgated an order for unrestricted submar1 ine warfare. When Josph P. Tumulty, Wilson's secretary, delivered the Associated Press bulletin announcing Germany's resumption of unrestricted warfare, January 31, 1917, Wils on stated, "This means war.... ${ }^{2}$ The German note, announcing that a blockade was to be placed around the British Isles, showed that Germany realized peace was impossible. The British Ambassador, wi th his ear to the ground, reported: "War has drawn gradually nearer and nearer to the United $S_{t}$ ates in spite of all their efforts." 3

The announcement of the blockade around the British Isles brought forth a rupture in diplomatic relations and on February 3 , 1917, Count von Bernstorff was handed his passport. In a statement issued to the press, Bernstorff said: "I am not surprised. Wy gorernment will not be surprised either. The people in Berlin knew what was bound to happen if they took the action they have taken. There was nothing left for the United States to do." The Wall Street Digest noted that the "upward movement in the price of stocks dates from the day the German Ambassador was handed his passports."

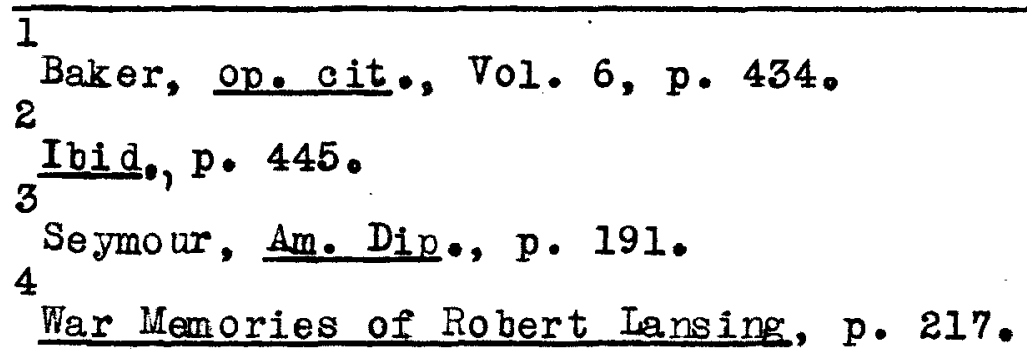


Throughout 1916 the news of German victories or peace offers had a most depressing effect on the stock met. These facts, bogether with the rejoicing in financial circles over the break with Germany, indicate the closeness of the economic relationship between the United States and the Allies.

After the rupture of relations with Germany, war was virtually inevitable. Yet Wilson hoped against hope that the Germans might aroid an overt act against the United States. But if their submarines again destroyed Ame rican ships and lives he would come before Congress again and recomment extreme measures. This was a wise decision, for pablic opinion in the United States was far from unanimous on the desirability of war. "I could not move faster," Wilson remarke to his secretary, "than the of our people would permit."

The exposure of the Zimmerman note, February 24, 1917, came as something of a shock to Americans to realize that Germany, if struck by the United States, would strike back in the New World. Imnediately a tremendgous wave of anti-German sentiment swept over the country, particularly in the hitherto apathetic south and southwest, where there was alarm over the threat of being conquered by Mexico. Nor was the immigration-conscious 1 Peterson, op. cit., p. 267 . 2 Bailey, op. cit., p. 642 . 
Pacific coast pleased by the proposed overtures to Japan. A more nearly united America was now one step nearer the brink.

On February 26, Wilson urged Congress to authorize the mounting of guns on American merchant ships bound for European waters, calling it "armed neutrality," and, realizing that further action by Congress was needed, called a secial session for April 6. 1917. A filibuster halted the request in congress, but the action was carried out March 4, through military powers of the executive office and expert gunners were to be supplied by the Navy. The sinking of two unarmed merchant ships, March 12 and 19, only added to the call for war.

The Zimmerman note and the actual sinkings convinced Wilson that peace was hopeless. The pressure on Wilson to request Congress to declare a state of war came from many sides and especially from people prominent in everyday affairs. A state of war between Germany and the United States actually existed said vicepresident Marshall in a speech at liontgomery, Alabama, on the 24 th. This opinion was echoed by Charles E. Hughes, Elihu Root and Theodore Roosevelt. "There is now a state of war, and the people of

1

Ibid, p. 643 .

Lit. Dig., IIV, $4($ March 17, 1917) p. 687. Millis, op. cit., pp. 404-405. 
the United States should recognize the fact," said Mr. Hughes. "Germany is making war on us and our reply most be either war or submission," affirmed Mr. Root. Colonel Roosevelt, after pointing out that Germany "had steaily waged war upon us" ever since her declaration of unrestricted sabmarine war on January 31, added: "Let as face the accomplished fact, admit that Germany is at war with us, and in turn wage war on Germany with all our energy and courage and regain the right to look the whole world in the eyes without flinching. ${ }^{1,2}$

Wilson's message to Congress, April 6, 1917, was greeted with wild oration. Of the 50 negative rotes in the House (373 to 50), 32 came from Republicans-- mastly of the western progressive wing-- one was that of an independent and the remaining one that of Meyer Iond on, the Socialist memer. There were, altogether, 520 Senators and Representatives; only 56, or about one in ten, had dared to cast their votes against the tide.

But if one dares to trust Mr. Tumulty's memory, there was another scene in the White Hoase that night, when the secretary talked alone with his chief in the Cabinet room. The applause

1

Iit. Dig., IIV, 12 (March 24, 1917) p. 801 . Roosevelt, Theodore: Fear God and Pake Your Own Part, p. 203. 3 Cong. Rec., 65th Cong. Special Session, Vol. 55, pt. 1, p. 420. 
from the sidewalk crowds as he had driven from the Capitol returned to the President's ears. "My message today," Tumulty remembers him say. "was a message of death for our young men. How strange it seems to applaud that." Afterward, in the secretary's account, the President broke down and wept, with his head on the Cabinet table.

It might have seemed logical for the United States to have declared war against both groups of belligerents, just as it had been proposed that she fight both England and France in 1812.

A logical answer was that Allied practices hurt only American property rights. The United States could lodge protests and perhaps collect damages when the war was over. The German submarine took American lives and there seemed to be no proper recompense for lives. So the United States fought Germany. As the Boston Globe remarked: "One was a gang of thieves; the other was a gang of marderers. On the whole we prefer the thieves but only as the lesser of two evils." ${ }^{2}$

Whether rightly or wrongly, Wilson followed the course of insisting upon the strict letter of the law-- at least as far as the Germans were concerned and when Germany felt impelled to act contrary to these "immutable principles" and "acirnowledged

\footnotetext{
$\overline{1}$ 2 Bailey, ㅇp. cit., p. 645 .
}

Tumulty, Joseph P.: Wood row Wilson as I know Him, p. 256. 
rights" war became inevitable. We had admitted the law of necessity in our earlier notes to Great Britain where trade only was involved; but we di d not recognize that the law of necessity could be invoked to justify putting the lives of our citizens in jeop1 ardy. Secretary of State Robert Lansing, said on June 9, 1915:

"But the sinking of passenger ships

involves principles of humanity which throw

into the background any spedial circumstances of detail that may be thought to affect the cases.... The government of the United States is contending for some thing much greater than mere rights of property or privileges of commerce. It is contending for nothing less high and sacred than the rights of humanity, which every government honors itself in respecting and which no Government is justified in resigning on behalf of those under its care and a uthority." 2

These grave words, and the acts to which they were the prelude, show us that in the last analysis it is the attack on human life, rather than the attack on property rights, which is most likely to start in motion the tides of resentment which can impelf a country like the United States into war. But perhaps the decisive factor was sympathy-- gradually shifting to the Allied cause.

Nearly everyone, even Theodore Roosevelt in September, 1914, thought.it "eminently desirable" to remain neutral. It was not until some months later that Roosevelt accused Wilson of "polI Dulles and Armstrong, op. cit., p. 3l. 2 "Papers relating to the Foreign Relations of the United States," 1915, Supplement, The World War, p. 481 . 
troonery" for not having protested the invasion of Belgium. His change of mind is not attributable minly to political motives, though his love of political invective undoubtedly played a part. What happened to him, what happened to President Wilson, happened to many other Americans, some sooner, some later. 'they saw a battle royal in progress, and in their hearts they took sides. Then, as the position which our government had taken from the very outset produced the material and legal grounds for participation, feeling and fact coalesced; we participated.

"A government can be ne utral," said water Hines Page, "but no man can be."

1

Dulles and Armstrong, op. cit., p. 33. 2 Hendrick, op. cit., Vol. 1, p. 361 . 


\section{BIBIIOGRAPHY}

BOOKS

Abrams, Ray H., Preachers Present Arms, New York, Round Table Press, Ine., 1933.

Adams, James Truslow, The March of Democracy, Vol. 4, America and World Power, New York, Charles Seribner's Sons, 1940 .

Allen, George H. and others, The Great War, Vol. 4, Philadelphia, George Barrie's and Sons, 1919.

Amerioan Labor Year Book, 1917-1918, New York, Philosophical Library, 1919.

Ange 11, Norman, Let the People Know, New York, The Viking Press, 1943.

Arnett, Alex Wathews, Claude Fitchin and the Wilson War Policies, Boston, Iittle, Brown and Co., 1937.

Bailey, Thomas A., A Diplomatic History of the American People New York, F. S. Crofts and Co., 1945 (Second Ed ition).

Baker, Ray Stannard, Woodrow Wils on Life and Letters, Vols . 5 and 6, Potomac Edition, New York, Charles Scribner's Sons, 1946.

Baruch, Bernard $H_{0}$, American Industry in the War, A report of the War Ind ustries Board (Marón 1921), New York, PrenticeHal 1, Inc., 1941.

Bemis, Samuel Flagg, A Diplomatic History of the United States, New York, Henry Holt and Co., 1936.

Brown, William Adam, The Church in America, New York, The MacHillan Co., 1922.

Bruntz, George G., Allied Propagande and the Collapse of the German Empire in 1918, Pa 10 Alto, California, Stanford University Press, Hoover War Library Publications, No. 13,1938 .

Bryan, William Jennings and Hary Baird, The Memoirs of William Jennings Bryan, Philadelphia, The John C. Winston Co., 1925. 
Clark, J. Ma urice, Hamilton, Walt on H., and Hoult on, Harold G., Readings in the Economics of War, Chicago, The University of Chicago Press, 1918.

Dulles, Allen W. and Armstrong, Hamilt on Fish, Can We be Neutral?, New York, Published by Harper and Brothers for Coancil on Foreign Relations, Inc., 1936.

Encrelo edia Britannica, Vol. 16, 14th Edition, New York, The Encyclopedia Bri tannica Company, 1945.

Engelbrecht, H. D. and Hanighen, F. C., Merchants of Death, New York, Dodd, Mead and Co., 1934.

Ford, James, Social Problems and Social Policr, New York, Ginn and Company, 1923.

Gerard, James W., Face to Face with Kaiserism, New Yor $x$, George H. Doran Co., 1918 .

Gillette, John M. and Reinhardt, James M., Problems of a Changing Social Order, New York, The Ameri can Book Company, 1942.

Grey, Viscount of Fallodon, K. G., Twenty-Five Years, New Yorix, Frederick A. Stokes Co., 1925 .

Haines, C. Grove and Hoffinan, Ross J. S., The Origins and Background of the Second World War, New York, Oxford Universi ty Press, 1947.

Hale, William Harlan, The Warch of Freedom, A Laymen's History of the American People, New Yor $k$, Harper and Brother's Publishers, 1947.

Halsey, Francis Whiting, The Literary Digest History of the World War, Vols. 4-10, New York, Funk and Wagnalls Co., 1919.

Hendrick, Burton J., The life and Letters of walter H. Page, Two vols., New York, Doubleday, Page and Co., 1923.

Howe, Frederic C., Why War?, New York, Charles Scribners and Sons Publishers, 1916 .

Klineberg, Otto, Social Psychology, New York, Henry Holt and Co., 1940 .

Knudson, Albert B., The Principles of Christian Ethicg, New York, Abingdon-Cokesbury Press, 1943.

Iansing, Robert, War Memoirs of Robert Lansing, Indianapolis and New Yor $k$, The Bobbs-Merrill Co., 1935. 
Lasswell, Harold D., Propaganda Technique in the World War, New York, Peter Smith, 1938 .

Latourette, Kenneth Scott, A History of the Expansion of Christianity, Vol. 7, Advance lhrough the Storm, New York, Harper and Brothers, 1945.

Iippmann, Walter, Public Opinion, New York, Harcourt, Brace and Co., 1922.

Lodge, Henry Cabot, The Serate and the League of Nations, New York, Charles Scribner's Sons, 1925.

Lowell, Lawrence A., Public Opinion in War and Peace, Cambridge, Harvard Universi ty Press, 1923.

Millis, Walter, The Road to War, America 1914-1917, Boston and New York, The Hought on Kiffl in Co., 1935.

Hock, James $R$. and Iarson, Cedric, Words that Won the War. The Story of the Committee on Public Information, 1917-1919, Princeton, Princeton University Press, 1939.

Ogburn, William F. and Nimkoff, Meyer H', Sociology, New York, The Houghton-Mifflin Co., 1946.

Ogg. Frederic Austin, The American Nation: A History, Vòl. 27, National Progress, New York, Harper and Brothers, 1918.

Peterson, H. C., Propaganda for War-- The Campaign against American Neutrality, 1914-1917, Norman, The University of Oklahoma Press, 1939 .

Ponsonby, Arthur M.P., Falsohood in War-Time, New Yor $k$, E. P. Dutton and Co., 1928.

Powys, John Cowper, The War and Culture: A Reply to Professor ifunsterberg, New York, G. Arnold Shaw, 1914.

Read, James Morgan, itrocity Propaganda, Published for the Universi ty of Louisville, New Haven, Yale University Press, 1941.

Rhodes, James Ford, History of the United States, Vol, 9, 18961909, New York, The Macllilian Co., 1929.

Riegel, Oscar W., Mobilizing for Cheos, New Haven, Yale University Press, $1 \overline{934 .}$

Riegel, Robert E. and others, An Introduction to the Social Sciences, New Yorik, D. Appleton-Century Co., 1941. 
Ross, Edward Alsworth, Social Psychology, New York, The MacMillan Co., 1912 .

Roosevelt, Theod ore, Fear God and Take Your Own Part, New York, George H. Doran Co., 1916 .

Salter, Sir Arthur; Thomason, Sir J. Arthur; Johnst on G. A.; Zimern, Alfred; Andrews, C. F.; Libby, Frederick J.; Atkinson, Henry A.; Steed, Wickham and others, The Causes of War, New Yorik, the MacMillian Co., 1932.

Schlesinger, Arthur ifeier, Political an Social History of the United States, New York, The Macililian Co., 1927.

Seymour, Charles, The Intimate Papers of Colonel House, Vol. 2, Boston and New York, The Houghton iffiflin Co., 1926.

Seymour, Charles, American Diplomacy During the World War, Baltimore, The John Hopkins Press, 1934.

Seymour, Charles, Woodrow Wilson a nd the Wor ld War, New Haven, Yale University Press, 1921.

Shippee, Lester Burre1l, Recent American History, New York, The MacMillan Co., 1924.

Slosson, Preston William, A History of American Life, Vol. 12, The Great Crusade and After, 1914-1928, New York, The Kacllilian Co., 1930.

Stearns, Raymond Phineas, Pageant of Europe, New York, Harco urt, Brace and Co., 1948 .

Smith, Bruce Lannes; Lasswell, Harold D. and Casey, Ralph D., Propaganda, Communication and Public Opinion, Princeton, The Princeton University Press, 1946.

Swain, Joseph Ward, Beginning the Twentieth Century, New York, W. W. Nort on Co., Inc., 1940.

Thorndike, I. I., Human Nature and the Social Order, New York, The Haclilian Co., 1940 .

Tumulty, Joseph P., Woodrow Wilson as I Know Him, New York, Doubleday, Page and Co., 1921.

Viereck, George Sylvester, Spreading Germs of Hate, New York, Horace Liveright, 1930 . 
Watters on Henrzy, Marse Henry an Autobiography, Two Vols., in one, New York, Ge orge H. Doran Co., 1919.

White Elizabeth Brett, American Opinion of France, New York, Alfred A. Knopf, 1927 .

Woolsey, Theodore D., Introduction to the Stady of Internation 1 Law, New York, Char les Deribner's Sons, 1878.

Young, Rimball, An Introduct ory Sociology, Revised Sition, New York, American Book Co., 1939 .

\section{NEWSPAPERS}

Directly or indi rectly quoted.

Aug usta, Georgia

Chronicle

Baltimore, Maryland

Ame rican

Sun

Boston, Massachusetts

Journal

Transcript

Brooklyn, New York

Eagle

Buffalo, New York

Time 9

Cheyenne, Wyoming

Ieader.

Chicago, Illinois

Herald

Cincinnati, Ohio Freie-Presg (German language)

Volksblatt (German language)

Cleveland, Ohio

Plain-Dealer

Press

Detroit, Michigan

Journal 
Kansas City, Missouri

Star

London, England

Blobe

Times

Louisville, Kent ucky

Courier-Journal

Memphis, Tennessee

Commercial-Appeal

Milwakkee, Wisconsin

Preo-Press

Journal

Sentinel

Mobile, Alabama

Register

Nashoille, Tennesisee

Tennessean

New Haven, Conneticicut

Journal-Courier

New York, New York

American

CaII

Commercial

Evening itail

Evening Post

Fatherland (National German Weekly)

Globe

Herald-Tribune

Herold (German language)

Journal of Comme rce

Morning Telegraph

Press

Staats-Zeitung (German language)

Sun

Times

WaIl Street Journal

World

Oshkosh, Wiscons in

Northwesterner

Peoria, Illinois

Journal 


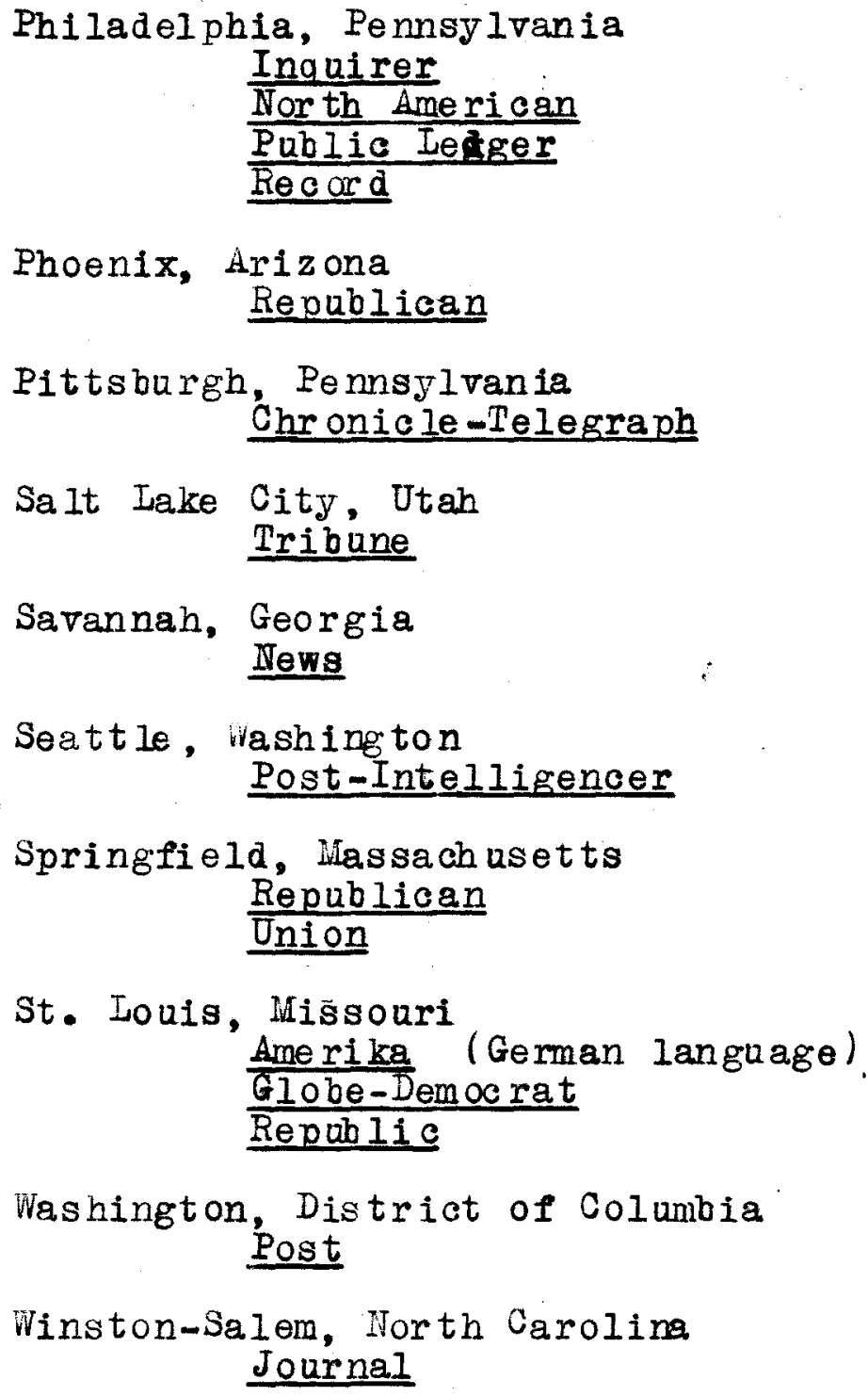

Winston-Salem, North Caroline Journal

\section{PERIODICAIS}

The Diary of Joseph Boebbels. Life Magazine, Vol. 24, No. 13, Harch 29, 1948, Time, Iife and Fortune Publishing Co., New York City, Published by Doubleday and Co., and claimed by the Alien Propety Custodian for the United States Government. 
The Iiterary Digest, (Public Opinion combined with the Iiterary Digest) Vols. 49m54, New York, Funk and Wagnalls Co.

Time ifagazine, Vo1. 27, No. 3, Janua ry 20, 1936, New York, Time, Life and Fortune Publishing Co.

\section{PERIODICALS}

Indirectiy quoted.

Bost on, Massachusetts

Christian Work and Evangelist

The Congregationalist

Chicago, Illinois

The Christian Century

The Continent

Milwaukee, Wiscontin

The Living Church

Newark, New Jersey

The Catholic Monitor

New York, New York

Christian Work

International

North Ame rican Review

The American Hebrew

The Churchman

The Independent

The New Republic

The Out look

Philadelphia, Pennsylvania

The Lutheran

GOVER MUENT DOCUME INTS

$\frac{\text { Congressional Record }}{\text { Part l. }}$ 65th Congress, Spef(dal Session, Vol. 55, 